\title{
Radiofrequency lesions of the dorsal root ganglion in the treatment of spinal pain
}

Citation for published version (APA):

van Kleef, M. (1996). Radiofrequency lesions of the dorsal root ganglion in the treatment of spinal pain. [Doctoral Thesis, Maastricht University]. Rijksuniversiteit Limburg.

https://doi.org/10.26481/dis.19960912mk

Document status and date:

Published: 01/01/1996

DOI:

10.26481/dis.19960912mk

Document Version:

Publisher's PDF, also known as Version of record

\section{Please check the document version of this publication:}

- A submitted manuscript is the version of the article upon submission and before peer-review. There can be important differences between the submitted version and the official published version of record.

People interested in the research are advised to contact the author for the final version of the publication, or visit the DOI to the publisher's website.

- The final author version and the galley proof are versions of the publication after peer review.

- The final published version features the final layout of the paper including the volume, issue and page numbers.

Link to publication

\footnotetext{
General rights rights.

- You may freely distribute the URL identifying the publication in the public portal. please follow below link for the End User Agreement:

www.umlib.nl/taverne-license

Take down policy

If you believe that this document breaches copyright please contact us at:

repository@maastrichtuniversity.nl

providing details and we will investigate your claim.
}

Copyright and moral rights for the publications made accessible in the public portal are retained by the authors and/or other copyright owners and it is a condition of accessing publications that users recognise and abide by the legal requirements associated with these

- Users may download and print one copy of any publication from the public portal for the purpose of private study or research.

- You may not further distribute the material or use it for any profit-making activity or commercial gain

If the publication is distributed under the terms of Article $25 \mathrm{fa}$ of the Dutch Copyright Act, indicated by the "Taverne" license above, 
Radiofrequency Lesions of the Dorsal Root Ganglion in the Treatment of Spinal Pain 
(C) Maarten van Kleef, Maastricht 1996 ISBN 9090096817

Vormgeving en druk: Datawyse I Universitaire Pers Maastricht Omslag illustratie: C.J.M. Langenberg 


\section{Radiofrequency Lesions of the Dorsal Root Ganglion in the Treatment of Spinal Pain}

\section{PROEFSCHRIFT}

ter verkrijging van de graad van doctor aan

de Rijksuniversiteit Limburg te Maastricht,

op gezag van de Rector Magnificus, Prof. mr. M.J. Cohen

volgens het besluit van het College van Dekanen,

in het openbaar te verdedigen op 12 september 1996 om 16.00 uur

door

Maarten van Kleef 


\section{Promotores:}

Prof. dr. S. de Lange

Prof. dr. M.E. Sluijter

\section{Beoordelingscommissie:}

Prof. dr. J.W. Arends (voorzitter)

Prof. dr. M. Beuls

Prol. dr. F. Spaans

Prof. dr. O. Sjaastad (University of Trondheim, Norway)

Dr. W.A. Zuurmond (Vrije Universiteit Amsterdam)

De publikatie van dit proefschrift is mede mogelijk gemaakt door de Nederlandse Stichting Pijnbestrijding en de afdeling Anesthesiologie van het Academisch Ziekenhuis Maastricht. 


\section{CONTENTS}

CHAPTER 1

Introduction 7

\section{CHAPTER 2}

History, electrophysical principles and the effect on nerve tissue of radiofrequency current 11

\section{CHAPTER 3}

Treatment of spinal pain with radiofrequency techniques General considerations $\quad 19$

\section{CHAPTER 4}

Treatment of spinal pain with radiofrequency techniques -

Procedures 29

\section{CHAPTER 5}

The morphological effects of radiofrequency lesions

on the dorsal root ganglion. An experimental study in the goat

CHAPTER 6

Effects and side effects of a radiofrequency lesion of the dorsal root ganglion in patients with cervical pain syndrome

CHAPTER 7

The effects of producing a radiofrequency lesion adjacent. to the dorsal root ganglion in patients with thoracic segmental pain

CHAPTER 8

Radiofrequency lesion adjacent to the dorsal root ganglion for cervicobrachial pain: a prospective double blind randomized study

CHAPTER 9

Summary and conclusions $\quad 91$

CHAPTER 10

Samenvatting en conclusies

Dankwoord 101

Curriculum Vitae 103 



\section{CHAPTER 1}

\section{Introduction}

Chronic pain is an important problem in daily medical practice. Apart from its psychosocial consequences for the individual patient, it has enormous socioeconomic impact on society. In 1991 the total cost of low back pain to the Netherlands economy was estimated at NLG 7.5 milliard (Van Tulder et al. 1995). The majority of chronic pain patients suffers from pain emanating from the spine and adjacent structures. It is this type of pain that is a frequent cause for disability and loss of mobility (Kelsey et al. 1979).

About $70-80 \%$ of the total adult population experiences acute low back or neck pain at some stage of their lives. The symptoms resolve spontaneously in the majority of cases but in $8-12 \%$ of patients the pain becomes chronic (Bland 1986, Valkenburg and Haanen 1982). Social and psychological factors start playing a role making the pain syndrome more complex (Bonica 1979, Sternbach 1986).

The mechanism of spinal pain is complex. In $15 \%$ of patients with low back pain a specific cause is found such as disc protrusion, infection, spondylolisthesis or a vertebral fracture (Spitzer et al. 1987). In the majority of cases the mechanism remains unclear despite thorough diagnostic investigations. When radiological abnormalities are found, they are often aspecific and fail to correlate with the patient's complaints (Friedenberg and Miller 1963, Heller et al. 1983, Jensen et al. 1994).

Wyke (1987) classifies the causes of spinal pain into primary, secondary, referred and psychogenic causes:

1. Primary pain is considered to be pain which originates from the vertebral column itself or from adjacent structures;

2. Secondary pain is considered to be a consequence of primary pain, possibly mediated by musle spasm;

3. Referred pain may be defined as pain perceived in a region of the body topographycally distinct from the region in which the actual pain source is located;

4. The term psychogenic pain is no longer accepted. This nomenclature suggests a strict dichotomy in pain classification in terms of 'somatic' versus 'psychogenic'. It is now generally accepted that pain should be described as a multidimensional phenomenon.

O'Brien (1984) further classifies primary pain, according to the source, into:

a. Pain which originates from the mobile segment and its associated structures (zygapophysial joints, discs);

b. Pain which emanates from the more superficial tissues which surrounds the vertebral column such as ligaments and muscle; 
c. Pain which is caused by involvement of the segmental nerves associated with the vertebral column.

Management of pain of spinal origin is directed to the cause of the pain provided that. diagnostic procedures have revealed a specific lesion that correlates with the patient's complaints. However, as mentioned, this approach only applies to a. small number of patients. Patients without a specific cause of pain are managed symptomatically by non-invasive conservative treatment such as medication, transcutaneous nerve stimulation, manual therapy and physical therapy. Nevertheless, there remains an important group of patients who do not have a specific lesion and who do not respond to these forms of symptomatic treatment. Further management of their pain then depends on the presence or absence of nociception. Nociceptive pain is defined as pain that originates from somatic structures and is perceived to be commensurate with tissue damage.

Diagnostic nerve blocks using a local anaesthetic solution are a useful tool in determining whether a nociceptive focus is present and if so where this is located. Even though this diagnostic technique has both technical and theoretical problems, which could lead to a false interpretation of the results, these blocks seem, at present, to be the best available method of analysing the nociceptive pattern.

When a diagnostic block has been succesful a more definitive interruption of the sensory innervation may be considered. In the past a surgical approach was used to obtain more permanent pain relief. Often this resulted in aggravating the pain problem in the deafferentated dermatomes (anesthesia dolorosa) (Bertrand 1975. Loeser et al. 1968, Loeser 1972).

A less destructive method is the use of high-frequency current which gives a controllable heat lesion in the adjacent tissue. Since high-frequencies were also used in radiotransmitters, the high-frequency current was named radiofrequency current (RF-current). The lesions made with this current were introduced as radiofrequency lesions (RF-lesions). The extent of the interrupting lesion may be controlled by varying the output of the RF-lesion generator. RF-lesions can be made at various locations. They may be directed at interrupting the sensory innervation from a specific nociceptive structure, such as the zygapophysial joint.

To interrupt nociceptive stimuli from a segmental region rather than from a specific structure, RF-lesions at the level of the dorsal root ganglion can be produced. This was first proposed by Uematsiu et al. (1974) who described a "percutaneous electrothermocoagulation of the spinal nerve trunk, glanglion and rootlets" as an alternative to open surgery. Uematsu's technique of radiofrequency thermocoagulation of the dorsal root ganglion wasi considered to be a relatively simple technique that could relieve pain and preserve motor function and proprioception. Siluijter and Mehta (1981) later improved this technique by introducing a small diameter temperature-monitoring electrode system. This should allow higher controllability as to the extent and localisation of the lesion. 
A radiofrequency lesion of the dorsal root ganglion (RF-DRG) is an intriguing site for a radiofrequency lesion for two reasons:

1. All nerve fibres conducting nociceptive information to the spinal cord, have their cell bodies in the dorsal ganglion. Lesions of the dorsal root ganglion should result in reducing nociceptive stimuli to the spinal cord;

2. A neurophysiological study (Letcher and Goldring 1968) suggested that RFlesions have a selective effect on small unmyelinated fibres (C-fibres), leaving myelinated fibres (A-delta fibres) relatively unaffected. If this hypothesis is correct, RF-DRG might reduce pain while leaving the other sensory qualities preserved.

The aim of this thesis was to evaluate the efficacy and safety of RF-DRG in the treatment of chronic spinal pain. More specifically, we sought to answer the following questions:

1. What are the morphological changes in the dorsal root ganglion as a result of an RF-DRG?

2. Are there signs of motor denervation after an RF-DRG?

3. What are the clinical effects of an RF-DRG on pain?

4. Is the treatment of chronic spinal pain by an RF-DRG better than placebo?

These questions were approached as follows:

1. Morphological changes in the dorsal root ganglion were evaluated using an experimental goat model. RF-DRG's were produced at the lumbar level in goats, using fluoroscopy, in line with clinical practice. The morphological effects of the radiofrequency current was studied using light microscopy and MIB-1 (Ki 67);

2. Possible denervation sequelae of an RF-DRG were assessed in patients with chronic cervicobrachialgia. Electromyography and sensory evoked potential were recorded before and 3 weeks after RF-lesioning in order to investigate unwanted damage to the myelinated fibres;

3. Clinical evaluation of an RF-DRG as a therapy for chronic spinal pain was done on a consecutive group of patients presenting with chronic thoracic pain. The segmental distribution of the initial pain was taken into account;

4. Placebo-controlled treatment effects were evaluated with a prospective double-blind randomised study in 20 consecutive patients with unilateral chronic cervicobrachialgia.

\section{REFERENCES}

1. Bertrand G. The 'battered' root problem. Orthopedic Clinics of North America 6:305-310, 1975.

2. Bland JH. Cervical spine syndromes. J Musculoskel Med 3:23-41, 1986.

3. Bonica JJ. Important clinical aspects of acute and chronic pain. In. Beers RE, Bassett EC (eds.). Mechanism of pain and analgesic compounds. Raven Press, New York, p. 193, 1979.

4. Friedenberg ZB, Miller WT. Degenerative disc disease of cervical spine. J Bone Joint Surg 45A:1171. 1178, 1963. 
5. Heller CA, Stanley P, Lewis-Jones B, Heller RF. Value of X-ray examinations of the cervical spine. Br Med J 287:1276-1279, 1983.

6. Jensen MC, Brant-Zawadzki MN et al. Magnetic resonance imaging of the lumbar spine in people without back pain. New Engl J Med 33:69-73, 1994.

7. Kelsey JL, White AA, Pastides H, Bisbee GE. The impact of musculoskeletal disorders on the population of the United States. J Bone Joint Surg 6:959-963, 1979.

8. Letcher FS, Goldring $\mathrm{S}$. The effect of radiofrequency current and heat on peripheral nerve action potential in the cat. J Neurosurg 29:42-47, 1968.

9. Loeser JD. Dorsal mizotomy for the relief of chronic pain. J Neurosurg 36:745-750, 1972.

10. Loeser JD, Ward AA, White LE. Chronic deafferentation of human spinal cord neurons. I Neurosurg 29:48-50, 1968.

11. O'Brien JP. Mechanism of spinal pain. In: Textbook of Pain. Eds.: Wall PD and Melzack R. Churchil Livingstone, pp. 240-251, 1985.

12. Sluijter ME, Mehta M. Treatment of chronic back and neck pain by percutaneous thermal lesions, in Lipton S (ed.): Persistant pain, modern methods of treatment, London: Academic Press, vol. 3, chap 8, 1981, pp 141-179.

13. Spitzer W, Le Blanc F, et al. Scientific approach to the assessment and management of activity-related spinal disorders. Report of the Quebec Task Force on Spinal Orders. Spine 12:7S, 1987.

14. Sternbach RA. Clinical aspects of pain. In: Sternbach RA (ed.). The psychology of pain. Raven Press. New York, pp. 223-239, 1986.

15. Uematsu S, Udvarhelyi GB, Benson DW, Siebens AA. Percutaneous radiofrequency rhizotomy. Surg Neurol 2:319-325, 1974.

16. Valkenburg HA, Haanen HLM. The epidemiology of low back pain. In: White AA, Gordon SL. (eds.), St. Louis, Mosby, pp. 9-22, 1982.

17. Van Tulder MW, Koes BW, Bouter LM. A lost-of-illness study of back pain in The Netherlands. Pain 62:233-240, 1995.

18. Wyke BD. The neurology of back pain. In: Jayson MIV (ed.). The lumbar spine and back pain. Edinburgh, Churchill Livingstone, pp. 56-99, 1987. 


\section{History, electrophysical principles and the effect on nerve tissue of radiofrequency current}

\section{HISTORY}

Percutaneous current lesions have been used in the treatment of chronic pain since Kirschner (1931) introduced the coagulation of the Gasserian ganglion in patients with trigeminal neuralgia in 1931. Kirschner used a diathermy apparatus delivering a $350 \mathrm{~mA}$ direct current to a needle with a $10 \mathrm{~mm}$ uninsulated tip which was placed in the Gasserian ganglion under fluoroscopic control. The speed and the simplicity of the thermocoagulation led to its widespread use in Europe and in the United States. Sweet and Mark (1953) demonstrated that the use of direct current produces lesions which have unpredictable and ragged borders which may vary in size by a factor 4 . These workers and Hunsperger and Wyss (1953), suggested that the use of a high frequency current might be more appropriate for this application. Since high frequencies of $300-500 \mathrm{kHZ}$ were also used in radiotransmitters, the current was aptly named radiofrequency (RF) current. The first commercially available RF-generator was produced in the late 1950's by S. Aranow and B.J. Cosman.

Mundinger et al. (1960) advocated the use of temperature measurement at the electrode tip when performing stereotactic brain surgery with a RF-current. They claimed that temperature measurement was the most important parameter in obtaining a constant lesion size.

Sweet and Wepsic (1974) introduced a more advanced technique for electrothermocoagulation of the trigeminal ganglion. They suggested that this improved technique made it posșible to alleviate pain and știll preserve proprioception and motor function of the trigeminal nerve.

The first clinical application of an RF-lesion in spinal pain was introduced by Shealy (1975) when he used an RF-probe to interrupt the posterior primary ramus of the segmental nerve in patients with facetal joint pain in the lumbar area.

Uematsu et al. (1974) used percutaneous RF-rhizotomy in clinical practice for patients with pain due to various causes. They introduced the technique as an alternative to open rhizotomy and stated that pain conducting fibres could be selectively deactivated without damaging large fiber sensory and motor function by using an RF-probe heated to controlled temperatures.

In the following years RF-lesions for various spinal pain syndromes were introduced. Sluijter and Mehta (1981) modified the original technique by introducing a small diameter (22 Gauge) temperature monitoring electrode system. This modification 
contributed to the safety of the method and currently RF-procedures are routinely performed.

Since the early 1970's, when RF-lesions for back pain were introduced, there have been many new technical developments. Furthermore, the superior quality of $\mathrm{C}$-arm image intensifiers and the development of small diameter electrodes have permitted the development of more sophisticated procedures.

\section{THE RADIOFREQUENCY LESION GENERATOR SYSTEM}

A modern RF-lesion generator (Fig. 1) has the following functions:

- Continuous on-line impedance measurement;

- A nerve stimulator;

- Monitoring of voltage, current and wattage during the RF-procedure;

- Temperature monitoring.

These features are important for the following reasons.

Electrical impedance is measured to confirm the continuity of the electrical circuit and to detect any short-circuits. The impedance signal can be converted to a varying audible pitch by the generator, which allows the various tissue interfaces to be 'heard' while the operator concentrates on the procedure. The impedance will vary from about $300 \mathrm{Ohm}$ to $600 \mathrm{Ohm}$ in the extradural tissue. Furthermore impedance monitoring is of special interest in cordotomies and in RF-disc lesions. In cordotomies the impedance increases above the level of 1000 Ohm on entering the spinal cord (Lipton 1979) thus indicating that the electrode is properly positioned. In RF-disc: lesions the impedance falls sharply as the electrode enters into the disc (Van Kleef et al. 1995), below the level of $200 \mathrm{Ohm}$.

Cosman et al. (1988) found that immediately after making a lesion, the electrical resistance increases to a higher level than before the lesion. This might indicate a change in tissue structure due to the formation of the lesion. The clinical importance of this phenomenon is not yet clear.

Nerve stimulator. Nerve stimulation is of great importance in RF-procedures. After placement of the needle under fluoroscopic control nerve stimulation is carried out to confirm the proper position of the electrode and to permit minor adjustments. Firstly, stimulation is carried out at $50 \mathrm{~Hz}$ to ensure the proximity of the electrode to the sensory fibres. Two $\mathrm{Hz}$ stimulation is performed to detect muscle contractions indicating needle placement that is too close to motor fibres.

Ford et al. (1984) has shown that if an electrode is actually resting on the nerve, a minimum stimulation level required to produce a discharge is 0.25 Volts ( V), for a tissue impedance of $500 \mathrm{Ohm}$. As one moves away from the nerve, at a distance of $1 \mathrm{~cm}, 2 \mathrm{~V}$ would be required, In this manner, stimulation threshold is an indicator for electrode nerve distance. 


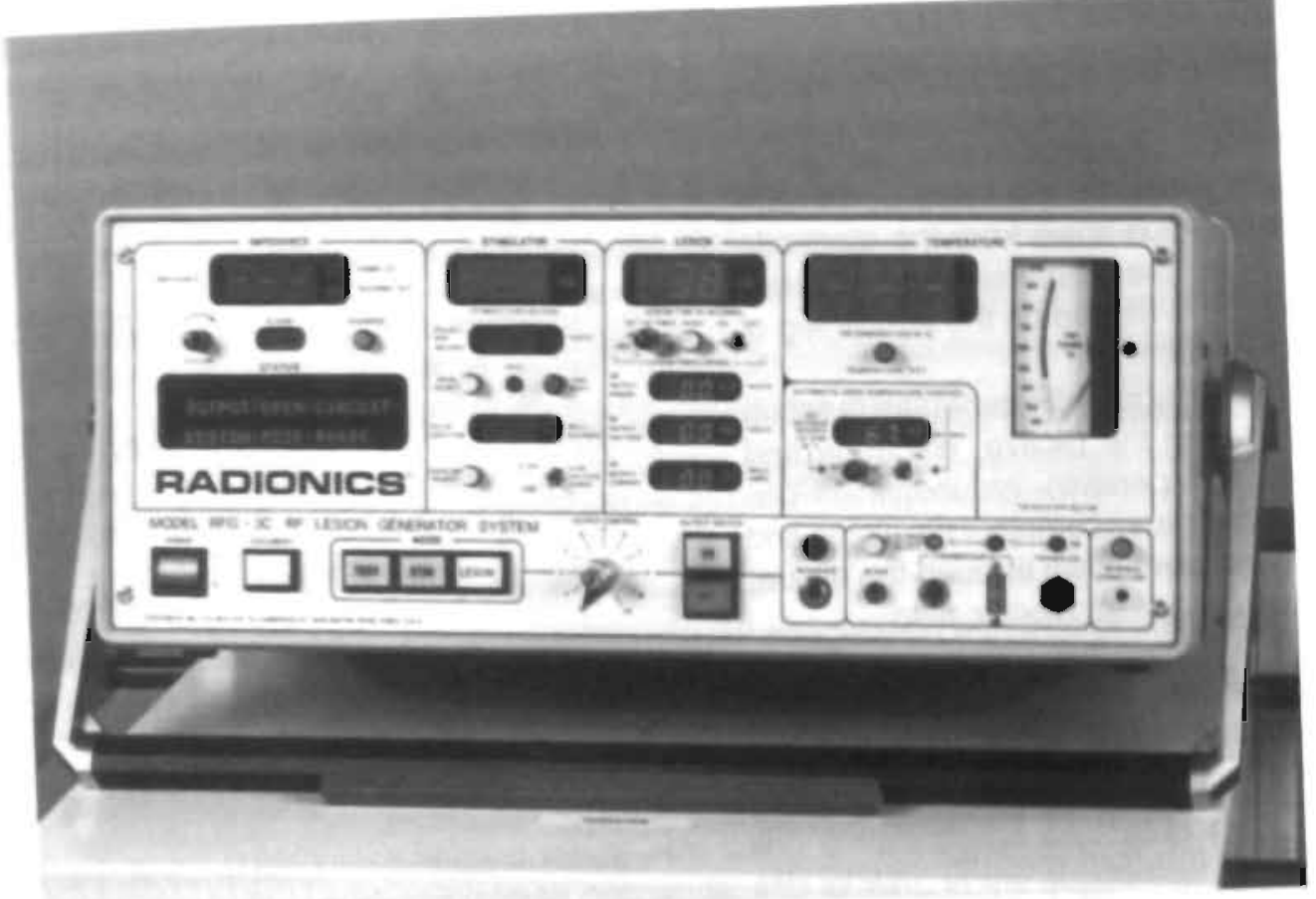

Figure 1. Radiofrequency lesion generator Radionics $3 \mathrm{C}$ with following functions: impedance monitor, stimulator, lesion parameters and temperature monitor.

Temperature monitoring. Temperature measurement is performed by the thermocouple technique, which has the advantage that temperafure can be measured in very small diameter electrodes. The thermocouple consists of a junction of two dissimilar metal elements, producing a thermodionic voltage which is proportional to temperature. The thermocouple is placed at the tip of the electrode which is in the hottest part of the lesion.

Though temperature is an important lesion parameter, it should be pointed out that temperature is only measured at the tip of the electrode and not in the more peripheral parts of the lesion area. Computer calculations indicate that the size of RF-lesions is strongly dependent on the local blood circulation, thus reducing the efficacy of using the tip temprature as a lesion size monitor. A typical RF-lesion will have a rapid drop off in temperature over the first few millimeters from the electrode tip (Cosman et al. 1984, Sluijter and Van Kleef 1995) (Fig. 2). 


\section{THEORETICAL ASPECTS OF RADIOFREQUENCY LESIONING}

Heat is generated in the tissue which surrounds the electrode by RF-current which flows from the electrode tip to the dispersive groundplate which is placed on the arm or leg of the patient.

The voltage of the generator is set up between the (active) electrode and the (dispersive) groundplate. The body tissues complete the circuit and RF-current flows through the tissue, resulting in an electric field.

This electric field creates an electric force on the ions in the tissue electrolytes, causing them to move back and forth at a high rate. Frictional dissipation of the ionic current within the fluid medium causes tissue heating. RF-heat is generated in the tissue. The electrode is heated by the tissue and nol the other way around.

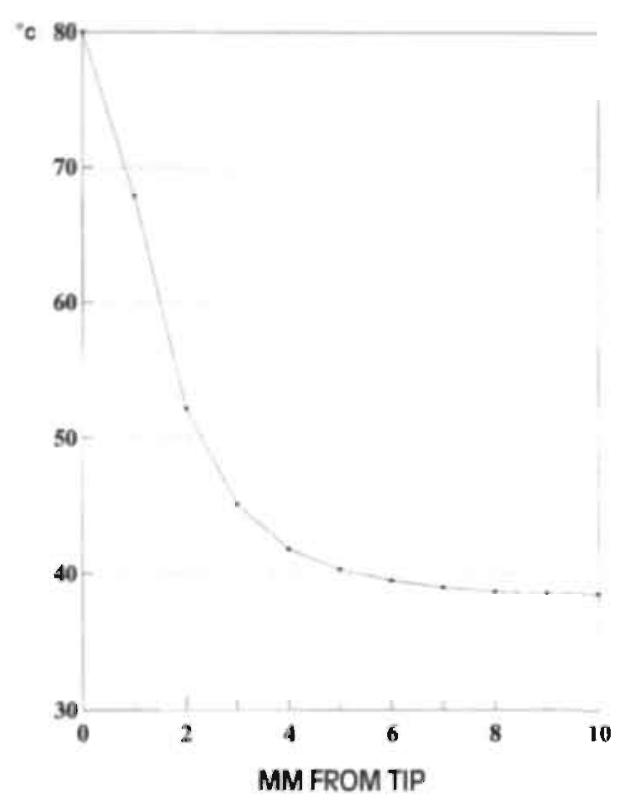

Figure 2. The distribution of tissue temperature as a function of distance from the active tip (computer model).

The size of the lesion also depends on the diameter of the electrode and the length of the uninsulated electrode tip. Cosman et al. (1984) was the first to determine lesion size for a given electrode tip size and temperature. They made dorsal root entry zone (DREZ) lesions in cats and studied the relationship between temperature, size, and duration of lesioning. They concluded that leaving the tip at $75^{\circ} \mathrm{C}$ the lesion size would only increase by about $20 \%$ beyond a lesion-time of 30 seconds. The lesion size did not further increase after 60 seconds.

Bogduk et al. (1987) also studied the shape and the size of lesions made by RF-electrodes. Experimental lesions were made in egg white and in fresh meat. They concluded that RF-lesions do not extend distal to the tip of the electrode, and that they extend radially around the electrode tip in the shape of an oblate spheroid with a maximal effective radius of $2 \mathrm{~mm}$ using a 21 Gauge electrode with a $3 \mathrm{~mm}$ exposed tip. In egg white experiments the first signs of coagulation appeared when the electrode reached about $62^{\circ} \mathrm{C}$ (range: $60^{\circ}$ to $65^{\circ} \mathrm{C}$ ). The maximal size of the lesion was attained once the 'working' temperature was reached. There was no discernible increase in the size of the lesion as this temperature was maintained once thermal equilibrium had been established. Bogduk advocated electrode placement parallel to the target structures as being a suitable position to achieve a 'proper' nerve lesion. 
Table 1.

\begin{tabular}{|c|c|c|c|c|c|}
\hline \multirow[b]{2}{*}{ Cosman (1984) } & \multicolumn{2}{|c|}{ Electrode dimensions } & \multirow{2}{*}{$\begin{array}{l}\text { Tip temperature } \\
65^{\circ}\end{array}$} & \multicolumn{2}{|c|}{ Transverse lesion size } \\
\hline & $21 \mathrm{G}$ & $3 \mathrm{~mm}$ tip & & $2.4 \mathrm{~mm}$ & $\operatorname{egg}$ \\
\hline \multirow[t]{3}{*}{ Bogduk (1987) } & $18 \mathrm{G}$ & $5 \mathrm{~mm}$ tip. & $80^{\circ}$ & $2.2 \pm 0.4 \mathrm{~mm}$ & $\operatorname{egg}$ \\
\hline & $22 \mathrm{G}$ & $4 \mathrm{~mm}$ tip & $80^{\circ}$ & $1.1 \pm 0.2 \mathrm{~mm}$ & $\operatorname{egg}$ \\
\hline & $22 \mathrm{G}$ & $4 \mathrm{~mm}$ tip. & $90^{\circ}$ & $1.6 \pm 0.2 \mathrm{~mm}$ & $\operatorname{egg}$ \\
\hline \multirow[t]{3}{*}{ Moringlane (1989) } & $21 \mathrm{G}$ & $2 \mathrm{~mm}$ tip & $60^{\prime}$ & $3.7 \mathrm{~mm}$ & rabbit cortex \\
\hline & & $2 \mathrm{~mm}$ tip & $70^{\circ}$ & $5.5 \mathrm{~mm}$ & fabbit cortex \\
\hline & & $2 \mathrm{~mm}$ tip & $80^{\circ}$ & $7.2 \mathrm{~mm}$ & rabbit cortex \\
\hline Vinas (1992) & $20 \mathrm{G}$ & $4 \mathrm{~mm}$ tip & $80^{\circ}$ & $4.9 \mathrm{~mm}$ & rabbit cortex \\
\hline
\end{tabular}

Survey of experimental lesion size, using differend electrode diameter, tip temprature and test medium.

Moringlane et al. (1989) studied experimental RF-coagulation with a computer based on line monitoring of temperature and power. They concluded that maximum 'volume' of the lesion is effectively obtained after 40 seconds and that the lesion size strongly depends on tip temperature and diameter of the probe.

Vinas et al. (1992) also studied lesion size using different time and temperature exposures, both in vivo using fresh egg white, and in vivo, in the subcortical white matter of rabbits. The coagulation size increased with higher temperatures and with larger probes. Using different times of lesioning at the same level of temperature, there was no significant increase of lesion size after 20 seconds.

Characteristics of various needle tip temperatures, probe diameters, exposed tip and lesion size of these studies are given in table 1.

\section{EFFECT OF RADIOFREQUENCY LESIONS ON NERVE TISSUE}

The effects of RF-current on nerve fibres is still controversial. Letcher and Goldring (1968) studied the effect of RF-current and heat on the nerve action potential of the saphenous nerve in cats. They found that RF-current and resulting heat blocked the smaller delta and $\mathrm{C}$-fibres before the alpha-beta group. The delta and $\mathrm{C}$ fibres are either blocked simultaneously or in sequence, with the delta group failing before the $\mathrm{C}$ fibres. This physiological study suggests the possibility of using heat to modify the function of the nerve in such a way that no functional fibres are left to transmit nociception whereas other nerve functions remain intact.

Morphological studies by Uematsu (1977) and Smith et al. (1981) found that RF-current indiscriminately damaged both small and large fibres. In addition, Uematsu (1977) described a preliminary histological study that demonstrated the effect of RF-thermocoagulation on the sciatic nerve of the cat.

In this study indiscriminate destruction of both small and large myelinated fibres occurred rather than selective destruction of smaller and less myelinated fibres. 
Smith et al. (1981) made RF-lesions ( $85^{\circ} \mathrm{C}$ for two minutes) in dogs by placing a temperature monitoring electrode under direct vision into the lumbar intervertebral foramen. In all lesions, there was a total loss of unmyelinated and nearly total loss of myelinated fibres. Lesions made at a temperature which increased from $45^{\circ}$ to $85^{\circ}$ C showed that all types of fibres were destroyed. Hamann and Hall (1992) produced $70^{\circ} \mathrm{C}$ (30 seconds) RF-lesions in saphenous nerves in rats. They also found that both unmyelinated and myelinated fibres were affected. These peripheral nerves, however, start to regenerate over the whole spectrum of nerve fibres within two weeks.

In conclusion, these studies indicate that RF-current directly applied to a peripheral nerve interrupts both thin and large nerve fibres. Regrettably there are no studies available at present which imitate the conditions of RF-lesions as used in medical practice today.

\section{DISCUSSION}

In the treatment of spinal pain there are two types of RF-lesions. In the first type, the object is to interrupt all sensory conduction. The lesions are made in order to interrupt the primary dorsal ramus in conditions were pain emanates from the zygapophysial (facet) joints in cervical and lumbar pain. In this technique the electrode is positioned as close to the target nerve as possible. (Bogduk et al. 1987, Lord et al. 1995). The necrotic zone is the zone of interest because in this procedure the intention is; total interruption of the primary ramus.

In the second type the object is to make a partial interruption of nerve conduction. These lesions are made at the level of the DRG and in these lesions the necrotic zone is an unwanted but unavoidable by-product of the RF-lesion. In these lesions the electrode is positioned a little away from the target structure to protect the DRG. from unwanted damage which could cause deafferentation pain.

Reviewing the literature. RF-procedures have a reasonably predictable lesion size depending strongly on the diameter of the electrode, and on the electrode tip temperature (Bogduk et al. 1987. Cosman et al. 1984, Moringlane et al. 1989, Vinas et al. 1992). All authors find that the 'time factor' of the lesion is not important once equilibrium temperature has been reached (after 20-40 seconds). Some variables, however, are not predictabie and they also govern the temperature in the peripheral zone of an RF-lesion. Examples of these variables are the effect of circulation and of tissue conductivity to heat. Therefore, lesion size may be variable at different locations within the body.

\section{CONCLUSION}

Some measurable parameters can determine the size of a lesion when using RF-current. Circulation effect and tissue conductivity, however, may produce a 
variation in lesion size. Conceming RF-DRG, no in vivo studies are available on the direct and indirect effect of the RF-current to the DRG nor are there any studies concerning lesion size in this area.

\section{REFERENCES}

1. Aronow S. The use of radiofrequency power in making lesions in the brain. J Neurosurg 17:431-438, 1960.

2. Bogduk N. Macintosh J, Marsland A. Technical limitations to the efficacy of radiofrequency neurotomy for spinal pain. Neurosurgery 20:529-535, 1987.

3. Cosman ER. Cosman BJ. Methods of making nervous system lesions, in Wilkins RH, Rengachary SS (eds.): Neurosurgery. New York, McGraw-Hill, 1984

4. Cosman ER, Rittman WJ. Nashold BS, Makachinas TT. Radiofrequency lesion generation and its effect on tissue impedance. Appl Neurophysiol 51:230-242, 1988

5. Ford DJ et al. Comparison of insulated and uninsulated needies for locating peripheral nerves with a peripheral nerve stimulator. Anest Analg 63:925-928, 1984.

6. Hamann W. Hall S. Acute effect and recovery of primary afferent nerve fibres after graded RF-lesions in anaesthetized rats. Br J Anest 68:443, 1992.

7. Hunsperger RW, Wyss OAM. Quantitative Ausschaltung von Nervengewebe durch Hochfrequenzikoagulation. Helv Physiol Acta 11:283-304, 1953

8. Kirschner M. Arch Klin Chir 167:761, 1931. Zur Elektrochirurgie

9. Letcher FS, Goldring S. The effect of radiofrequency current and heat on peripheral nerve action potential in the cat. J Neurosurg 29:42-47, 1968

10. Lipton S. The treatment of cancer pain, in: Lipton S (ed.), Relief of pain in clinical practice. Oxtord. Blackwell 1979, pp 126-177.

11. Lord SM, Barnsley L., Bogduk N. Percutaneous radiofrequency neurotomy in the treatment of cervical zygapophysial join pain: a caution. Neurosurg 36:732-739, 1995.

12. Moringlane JR, Koch $\mathrm{A}$, Schäfer $\mathrm{H}$, Ostertag $\mathrm{ChB}$. Experimental radiofrequency (RF) coagulation with computer-based on line monitoring of temperature and' power. Acta Neurochir 96:126-131, 1989

13. Mundinger F. Reichent T. Gabriel E. Untersuchungen zui den physikalischen und technischen Voranssetzungen einer dosierten Hochfrequenzkoagulation bei stereotaktischen Hirnoperation. Z Chir 19:1051-1063, 1960.

14. Shealy C.N. Percutaneous radiofrequency denervation of spinal facets. J Neurosurg 43:448-451 1975.

15. Sluijter ME, Mehta M. Treatment of chronic back and neck pain by percutaneous thermal lesions, in Lipton S (ed.): Persistant pain, modern methods of treatment, London: Academic Press, vol. 3, chap 8. 1981, pp 141-179.

16. Sluijter ME, Van Kleef M. Factors governing the size of radiofrequency lesions - description of a. computer model. Abstract 1st Scientific Meeting of the European Federation of IASP Chapters. Pain in Europe, Verona, May 18-21, 1995

17. Smith HP. McWhorter JM. Challa VA. Radiofrequency neurolysis in a clinical model, J Neurosurg 55:246-253, 1981.

18. Sweet WH. Mark VH. Unipolar anodal electrolyte lesions in the brain of man and rat: report of five. human cases with electrically produced bulbar or mesercephalic tractotomies. AMA Arch Neurol. Psychiatry 70:224-234, 1953.

19. Sweet WH, Wepsic JG. Controlled thermocoagulation of trigeminal ganglion and rootiets for difterential destruction of pain fibres. J Neurosurg 39:143-156, 1974 
20. Uematsu S. Percutaneous electrothermocoagulation of spinal nerve trunk, ganglion and rootlets. In: Schmidel HH, Sweet WS, eds. Current technique in operative neurosurgery, New York: Grune and Stratton, 1977. pp 469-490.

21. Uematsu S, Udvarhelyi GB, Benson DW, Siepens AA. Percutaneous radiofrequency rizotomy. Surg Neurol 2:319-325, 1974.

22. Van Kleef M, Barendse GAM, Lousberg R, Van Suijlekom JA, Dingemans WAAM, Bulstra SK, Sluijter ME. Eerste klinische ervaringen met radiofrequente laesie van de discus intervertebralis bij patiệnten met lage rugklachten. Ned Tijd Pijn Pijnbestrijding 15:13-17, 1995.

23. Vinas FC, Zamorano L, Dujovny M, Zhao JZ, Hodgkinson D, Ho KL. Ausman JI. In vivo and in vitro study of the lesions produced with a computerized radiofrequency system. Stereotact Funct: Neurosurg 58:121-133, 1992. 


\title{
CHAPTER 3
}

\section{Treatment of spinal pain with radiofrequency techniques - General considerations}

\author{
M. van Kleef \\ M.E. Sluijter
}




\section{GENERAL CONSIDERATIONS}

Spinal pain located in the cervical and lumbar area is frequently encountered in medical practice. Some studies (Hult 1954, Lawrence 1969, Mayer et al. 1991, Valkenburg and Haanen 1982) indicate that $70-80 \%$ of an adult working population experience cervical or lumbar pain at some stage of their life. In $15 \%$ of patients specific pathology is found such as disc herniation, spondylolisthesis, spinal stenosis or infections (Spitzer et al. 1987). In the remaining majority of patients the pain resolves within a few weeks and in about two months $80 \%$ of patients return to function. In about $5-12 \%$ of this population the complaints last for a longer period (Bland 1986, Mayer et al. 1991, Valkenburg and Haanen 1982) and generally after 6 months of pain, spontaneous relief is not to be expected.

\section{Classification}

Following the classification of chronic pain (Merskey and Bogduk 1994), spinal pain is defined as pain which is perceived as arising from the vertebral column or its adnexa. The location of the pain can be described in terms similar to those used to describe the regions of the vertebral column: cervical, thoracic and lumbar spinal pain.

There are several ways to classify spinal pain.

First: the following neurophysiological types of pain are relevant:

- Nociceptive pain is pain which is perceived to be commensurate with tissue damage. This type of pain originates from somatic structures. It is well localized and described as sharp aching, throbbing or pressure-like;

- Neuropathic pain is pain which is sustained by a site of aberrant somatosensory processing in the peripheral nerves, posterior roots, spinal cord or in an area of the brain (Bennet 1994). This type of pain is strongly suggested when dysaesthesia or hypaesthesia occurs in a region of motor or autonomic dysfunction (Roberts 1986);

- Sympathetic mediated pain may occur following injury to soft tissue, peripheral nerve or central nervous system. This type of pain is probably induced or sustained by a process that involves afferent activity in the sympathetic nervous system (Roberts 1986).

Second: spinal pain may be classified according to the source of pain. Wyke (1987) classifies into primary, secundary, referred and psychogenic pain. Primary pain is considered to be pain originating from structures of the spine itself or from adherent structures.

Secondary pain mechanisms may set up a vicious cycle either by producing muscle spasm. Referred pain may be defined as pain perceived in a region of the body which is topographically distant from the region in which the actual source of pain is located (Merskey and Bogduk 1994). 
The term "psychogenic pain" is no longer accepted. This led to the differentiation of pain into psychogenic versus organic pain (Lewis 1972). More recently various terms have evolved such as respondent behaviour and operant behaviour. Respondent behaviour is termed appropriate as a response to a nociceptive stimulus and unrelated to a learned reaction or influenced by the environment. Operant behaviour, on the other hand, is considered to be related to the patient's past learning and influenced by the current environment.

One has to realize that respondent and operant reactions apply in many cases and that even patients with significant organic lesions may develop secondary emotional changes justifying attention to psychological aspects (Fordyce 1976). On the other hand the prominent presence of operant factors in patients with spinal pain should not lead to exclusion of somatic treatment if organic pathology is present as well. These patients need attention to both organic and psychological aspects of their pain (Flor et al. 1992).

O'Brien (1984) further classifies primary causes of spinal pain into:

- Pain originating from the motion segment and its associated structures (zygapophysial joints and discs);

- Pain emanating from the more superficial tissues surrounding the vertebral column such as ligaments and muscles:

- Pain caused by involvement of the segmental nerve.

Third: there are several classifications which are based on clinical symptomatology (Spitzer et al. 1987, Waddell et al. 1982).

\section{Nerve supply of the spine}

The innervation of the spine is complex and it is well described in the articles on this subject by Bogduk et al. (1979, 1981, 1982, 1983, 1988) and Groen et al. (1990). On the cervical level the anterior aspect of the dura and the posterior longitudinal ligament and the dorsal aspect of the annulus fibrosus are innervated by the sinuvertebral nerve. Each of the cervical sinuvertebral nerves arise from a somatic and from an autonomic root. The somatic root stems from the ventral ramus at each segmental level, while the autonomic roots are derived from the vertebral nerve. This vertebral nerve accompanies the vertebral artery through the foramina transversaria and is formed by the grey rami communicantes, from the sympathetic trunk and from the stellate ganglion.

The posterolateral and lateral aspects of the cervical discs are innervated by the vertebral nerve. The posterior compartment of the spine is innervated by the posterior primary rami of the segmental nerve. These rami branch off the segmental nerve immediately after it exits from the foramen. It then curves posteriorly in a groove formed by the superior articular and transverse processes. It divides into a medial and lateral branch. 
The facet joints are innervated by the medial branch of the dorsal ramus, in such a way that each joint is served by multiple segmental levels.

On the lumbar level the posterior compartment of the spine is innervated by the posterior primary ramus of the segmental nerve (fig.1). This nerve branches off the segmental nerve immediately after it exits from the foramen and it curves posteriorly in a groove formed by the superior articular and transverse processes. It divides into a medial and lateral branch. The medial branch innervates the posterior joints in such a way that each joint is served by at least three segmental levels.

The anterior aspect of the dura and the posterior longitudinal ligament are innervated by the sinuvertebral nerve. This nerve is formed just outside the intervertebral foramen from contributions from the main segmental nerve and from the grey ramus communicans. It then runs back into the spinal canal through the foramen, running somewhat cranial to the disc. The outer layers of the annulus fibrosus are richly innervated (Bogduk et al. 1981, Coppes et al. 1990). The posterolateral part is innervated by small branches of the anterior primary ramus. The lateral and anterolateral part are innervated by rami of the grey ramus communicans. These are afferent fibres which are not part of the sympathetic system but which are travelling with it on their way to the dorsal root ganglion, where their cell bodies are. The same can be said for branches of the sympathetic chain which innervate the anterior part of the annulus fibrosus and the anterior longitudinal ligament. These last fibres too then reach the dorsal root ganglion via the communicating ramus.

\section{Diagnosis}

The diagnosis of spinal pain is based on history, physical examination, $\mathrm{X}$-rays and scans. In the history of the patient, distribution of pain may be helpful (Dwyer et al. 1990, Marks et al. 1989) but it is not pathognomonic. Pain referral patterns tend to 
overlap, both from structures within one segment (Mooney and Robertson 1975) and from structures in different segments (McCall et al. 1979).

Physical examination includes a neurological examination, examination of the function of the spine, examination of involvement of the sympathetic system and examination of tenderness over the various structures. Neurological examination may reveal the presence of neurogenic pain. Impaired function may indicate pain which emanates from mechanical structures such as the zygapophysial joints or the disc. Paravertebral tenderness and pain on hyperextension of the cervical or lumbar spine may be a symptom of facet joint pain but these symptoms are unreliable signs for such a diagnosis (Revell et al. 1992). Midline tenderness may suggest pain emanating from the intervertebral disc.

$\mathrm{X}$-rays, CT and MRI scans may reveal morphological abnormalities but there is no relationship between anatomical findings and pain (Friedenberg et al. 1963, Heller et al. 1983, Jensen et al. 1994). These investigations are therefore only valuable to confirm a clinical diagnosis.

History, physical examination and imaging procedures therefore are only of benefit to make a tentative diagnosis. This tentative diagnosis then has to be confirmed by diagnostic blocking either of potentially pain producing structures in the spine or of nerves conducting nociceptive stimuli. Potentially painful structures include the zygopophysial joints, and the cervical and lumbar dics (Bogduk and Marsland 1988. Kuslich et al. 1991. Marks et al. 1992, Sluijter 1988). Relevant nerves are the exiting segmental nerves or the sympathetic chain (Nash 1986, Pernak 1988, Sluijter and Mehta 1981, Stolker et al. 1994, Vervest et al. 1991, Wilkinson 1984).

At first sight diagnostic blocking seems to be the obvious method to confirm a tentative. diagnosis. There are both theoretical and practical difficulties however which limit its usefulness. If there is a state of nociceptive input into the dorsal horn normal input may equally contribute to the neurophysiological processes causing pain. This was found by Kibler and Nathan (1960) who blocked the popliteal nerve in a patient with radicular pain due to a prolapsed disc. The injection relieved the pain in the lower leg. Similarly' Xavier (1988) and Abram (1988) concluded that the nociceptive focus may' be located proximal as well as distal to the site of a successful diagnostic block.

Practical difficulties may lead to both false positive and false negative diagnostic. blocks. A false positive block may result from overflow of local anaesthetic solution to adjacent structures, for instance to the epidural space. A false negative block may' result from inadvertent injection into a blood vessel. Apart from these technical pitfalls. it has to be kept in mind that an adequate interpretation of the result of the block by the patient is an essential link. Some patients may be so overwhelmed by the hospital environment that they may indicate either a false positive or false negative response. Due to these factors, false positive responses to a single prognostic block are found in $27 \%-50 \%$ of patients (Barnsley et al. 1993A, Gallagher et al. 1994, North et al. 1994). For this reason some authors advise controlled blocks with the use of different. 
local anaesthetic solution with a different duration of action (Barnsley et al. 1993B, Lord et al. 1995).

In conclusion a tentative diagnosis in spinal pain is based on the history of the patient, distribution of the pain, physical examination and on radiological findings. Diagnostic nerve blocks, in spite of their limitations, are a useful tool to confirm the diagnosis in spinal pain. Moreover these blocks devise a strategy for treatment with radiofrequency (RF) lesions.

\section{Treatment}

There is a number of modalities of somatic treatment which is available for spinal pain. In pain medicine they are usually considered in the following order:

- Conservative measures;

- Causative treatment;

- Invasive treatment reducing nociceptive input;

- Epidural stimulation;

- Intraspinal administration of opioids.

Conservative measures always come first such as, medication, physical therapy or transcutaneous nerve stimulation. If this regimen fails to control the pain, the possibility of causative treatment (like operation) should be considered in the group of patients who have specific pathology.

If no specific pathology is present invasive techniques such as RF-lesions may be considered.

RF-lesions intend to reduce nociceptive input. A complete reduction may be aimed for if the nociceptive input is generated in a small, circumscript area. In practice this situation only occurs when pain emanates from the facetal joints. The RF-lesion of the posterior primary ramus intends to denervate the facetal joint, although this goal may not always be accomplished (Oudenhoven 1977).

In all other RF-techniques a partial reduction of input is sought. This is because a complete interruption of input does not invariably relieve and may even increase pain (Loeser et al. 1968, Loeser 1972). Such a partial reduction may be accomplished in various ways. In the case of the dorsal root ganglion the lesion is made adjacent to the ganglion with the intention of having the dorsal part of the ganglion in the peripheral zone of the lesion where moderate temperatures prevail. The lesion in the sympathetic chain is partial by its own nature because the target structure is larger than the size of an RF-lesion.

RF-lesions are not suitable to treat every type of spinal pain. On theoretical grounds the method is not suitable to treat neuropathic pain (Stolker et al. 1993) since in this condition the pain is caused by damage to a nerve rather than to an increase in 
nociceptive input. RF-lesions are therefore only indicated in suitable cases of nociceptive and of sympathetic mediated pain.

Additionally the distribution of pain is important to make the choice for this form of treatment. Pain with a wide-spread distribution is unlikely to respond satisfactorily.

RF-procedures are advocated for their controllability, they are well tolerated and they have few adverse effects (Nash 1986, North et al. 1994, Sluijter 1988, Stolker et al. 1993, Van Kleef et al. 1993, Vervest et al. 1991).

The effect of RF-lesions may be partial or temporary (North et al. 1994, Sluijter 1988, Van Kleef et al. 1993). This is an aim which is well worth pursuing however since a partial reduction of the intensity of the pain makes the pain more acceptable to the patient. This may promote better conditions for rehabilitation.

Treatment with RF-lesions is usually considered if pain persists for longer than 6 months despite conservative treatment. (Boersma et al. 1996). Epidemiological studies however indicate that spontaneous recovery of spinal pain is unlikely to occur after three months (Mayer et al. 1991, Spitzer et al. 1987). There might therefore be a case for the use of RF-lesions at an earlier stage.

Epidural spinal cord stimulation is generally indicated in case of neuropathic pain following failed back surgery (Le Doux and Langford 1993, North et al. 1993). Spinal administration of opioids is still a controversial subject in the treatment of spinal pain.

\section{REFERENCES}

1. Abram SE, Pain mechanisms in lumbar radiculopathy. Anesth Analg 35:1135-1137, 1988.

2. Barnsley $L_{n}$ Lord $S M$, Bogduk $N$. Comparative local anaesthetic blocks in the diagnosis of cervicat zygapophysial joint pain. Pain 55:99-106, 1993A.

3. Barnsley L. Lord S, Wallis B, Bogduk N. False-positive rates of cervical zygapophysial joint blocks. Clin.J Pain 9:12-130, 1993B.

4. Bennet GJ. Neuropathic pain. Chapter in Textbook of Pain. Wall PD and Melzack $A$ (eds.). Churchilli Livingstone, 1994.

5. Bland JH. Cervical spine syndromes. J Musculoskel Med 3:23-41, 1986.

6. Boersma FP, Van Kleef M, Rohof OJJM, Stolker RJ, Touw PPJ, Zuurmond WWA. Richtijinen. Anesthesiologische Pijnbestrijding, (in press), 1996.

7. Bogduk N. Lumbar dorsal ramus syndrome. Med J Aust 2:537-541, 1980.

8. Bogduk $N$. The clinical anatomy of the cervical dorsal rami. Spine 7:319-330, 1982

9. Bogduk N. The innervation of the lumbar spine. Spine 8:286-293, 1983

10. Bogduk N. Long DM. The anatomy of the so-called "articular nerves" and their relationship to tacet denervation in the treatment of low-back pain. J Neurosurg 51:172-177, 1979.

11. Bogduk N. Marsland A. The cervical zygapophysial joints as a source of neck pain. Spine 13:610-617, 1988 ,

12. Bogduk N. Tynan W. Wilson AS. The nerve supply to the human intervertebral discs. J Anat 132:39-56. 1981

13. Bogduk N. Wilson AS. Tynan W. The human dorsal rami. J Anat 134:383-397, 1982 
14. Bogduk N. Windsor M, Inglis A. The innervation of the cervical intervertebral discs. Spine 13:2-8, 1988.

15. Coppes MH, Marani E, Thomeer RTWM, Oudega M, Groen GJ. Innervation of annulus fibrosis in low back pain. Lancet 336:189-190, 1990.

16. Dwyer A, Aprill C, Bogduk N. Cervical zygapophysial joint pain patterns I: a study in normal volunteers. Spine 15:453-457, 1990.

17. Flor H, Fydrich $T$, Turk DC. Efficacy of a multidisciplinary pain treatment centers: a meta-analytic review. Pain 49:221-230, 1992.

18. Fordyce WE. Behavioural methọds fọr chrọnic pain and illness. Mosby CV, St. Louis, 1976.

19. Friedenberg ZB, Miller WT. Degenerative disc disease of cervical spine. J Bone Joint Surg 45A:1171$1178,1963$.

20. Gallagher J, Petricciore PL, Wedley JR et al. Radiofrequency facet joint denervation in the treatment of low back pain: a prospective controlled double-blind study to assess its efficacy. The Pain Clinic 7:193-198, 1994

21. Groen GJ, Baljet B. Drukker J. Nerves and nerve plexuses of the human vertebral column. Am J Anat 188:282-296, 1990.

22. Heller CA, Stanley P, Lewis-Jones B, Heller RF. Value of X-ray examinations of the cervical spine. Br Med J 287:1276-1279, 1983.

23. Hult $L$. The munkford investigation. Acta Orthop Scand 16:1, 1954.

24. Hult L. Cervical, dorsal and lumbar syndromes. Acta Orthop Scand 17:1, 1954.

25. Jensen MC, Brant-Zawađzki MN et al. Magnetic resonance imaging of the lumbar spine in people without back pain. New Engl J Mẹd 33:69-73, 1994.

26. Kibler RF, Nathan PN. J Neurol Neurosurg Psychiatr 23:91, 1960.

27. Kuslich S, Ulstrom CL, Michael CJ. The tissue origin of low back pain and sciatica. Orthopedic Clinics of North America 22:181-187, 1991.

28. Lawrence JS. Disc degeneration. Its frequency and relation to symptoms. Ann Rheum Dis 28:121, 1969.

29. Le Doux MS, Langford KH. Spinal cord stimulation for failed back syndrome. Spine 18:191-194, 1993.

30. Lewis A. A psychogenic: a word and its limitations. Psychol Med 2:209-214, 1972.

31. Loeser JD. Dorsal thizotomy for the relief of chronic pain. J Neurosurg 36:745-750, 1972.

32. Loeser JD, Ward AA, White LE. Chronic deafferentation of human spinal cord neurons. I Neurosurg 29:48-50, 1968.

33. Lord SM, Barnsley L, Bogduk N. The utility of cornparative local anesthetic blocks versus placebocontrolled blocks for the diagnosis of cervical zygapophysial joint pain. Clin .J Pain 11:208-213, 1995.

34. Marks RC. Distribution of pain provoked from lưmbar facet joints and related structures during diagnostic spinal infiltration. Pain 39:37-40, 1989.

35. Marks A.C, Houston T. Thulbourne T. Facet joint injection and facet nerve block: a randomised comparison in 86 patients with chronic low back pain. Pain 49:325-328, 1992.

36. Mayer T. Mooney V, Galchel F. Contemporary conservative care for painful spinal disorders, Lea and Febiger, Philadelphia, 1991, p 4.

37. McCall IW. Park W. O'Brien JP. Induced pain referral from posterior lumbar elements in normal subjects. Spine 4:441-446, 1979.

38. Merskey and Bogduk N. Classification of chronic pain. Internationai Association of the Study of Pain, 1994.

39. Mooney V. Robertson J. The facet syndrome: Clin Orthop 115:149-156, 1976.

40. Nash TP. Percutaneous radiofrequency lesioning of dorsal root ganglia for intratable pain. Pain 24:67-73, 1986.

41. North RB, Kidd MA, Zahurak M, James LS, Long DM. Spinal cord stimulation for chronic, intractable pain. Neurosurg 32:384-395, 1993.

42. North RB, Ham M, Zahurak M, Kidd DH. Radiofrequency lumbar facel denervation: analysis of prognostic factors. Pain $57: 77-83,1994$. 
43. O'Brien JP. Mechanism of spinal pain. In: Textbook of Pain. Eds.: Wall PD and Melzack R. Churchil Livingstone, p. 240-251, 1985.

44. Oudenhoven RC. Paraspinal electromyography following facet rhizotomy. Spine 2:299-304, 1977.

45. Pernak J. Percutaneous radiofrequency thermal lumbar sympathectomy and its clinical use. Eburon Delt. Thesis 1988.

46. Revel ME, Listrat VM, Chevalier XJ. Dougados M. Vallee C, Wybier M, Amor B. Facet joint block for low back pain: Identifying predictors of a good respons. Ach Phys Med Rehab 73:824-828, 1992.

47. Roberts WJ. A hypothesis on the physiological basis for causalgia and related pains. Pain 24:297-311. 1986.

48. Sluijter ME. The use of radiofrequency lesions for pain relief in failed back patients. Int Disabil Studies 10:37-43, 1988.

49. Sluijter ME, Mehta M. Treatment of chronic back and neck pain by percutaneous thermal lesions, in Lipton S (ed.): Persistant pain, modern methods of treatment, London: Academic Press, vol. 3, chap 8, 1981.pp 141-179.

50. Spitzer W, Le Blanc F, et al. Scientific approach to the assessment and management of activity-related spinal disorders. Report of the Quebec Task Force on Spinal Orders. Spine 12:7S, 1987.

51. Sri Kantha K. Radiofrequency percutaneous lumbar sympathectomy; technique and review of indications, in Racz GB (ed.): Techniques of neurolysis, Boston, Kluwer 1989, pp 171-184.

52. Stolker RJ, Sluijter ME, Rohof OJ. Meer pijn door behandeling. Ned Tijdschr Geneeskd 137:1539$1542,1993$.

53. Stolker RJ, Vervest ACM, Groen GJ. The treatment of chronic thoracic segmental pain by radiofrequency percutaneous partial thizotomy. J Neurosurg 80:986-992, 1994.

54. Valkenburg HA, Haanen HLM. The epidemiology of low back pain. In: White AA, Gordon SL (eds.). St. Louis, Mosby, p. 9-22; 1982.

55. Van Kleef M, Spaans F, Dingemans W, Barendse GAM, Floor A. Sluijter ME. Effects and side effects of a percutaneous thermal lesion of the dorsal root ganglion in patients with cervical pain syndrome. Pain 52:49-53, 1993.

56. Vervest ACM, Stolker RJ. The treatment of cervical pain syndromes with radiofrequency procedures. Pain Clin 4:103-112, 1991.

57. Waddell G, Main CJ, Morris EW, Venner RM, Rae PS, Sharmy SH, Galloway H. Normality and reliability in the clinical assessment of backache. Br Med J 284:1519-1523, 1982

58. Wilkinson HA. Radiofrequency percutaneous upper thoracic sympathectomy. N Engl J Med 311:3437. 1984 .

59. Wyke BD. The neurology of back pain. In: Jayson MIV (ed.). The lumbar spine and back pain. Edinburgh, Churchill Livingstone. pp. 56-99, 1987.

60. Xavier AV, McDalal J, Kissin I. Relief of sciatic radicular pain by sciatic nerve block. Anesth Analg $67: 1177-80,1988$. 
CHAPTER 4

\title{
Treatment of spinal pain with radiofrequency techniques - Procedures
}

\author{
M. van Kleef \\ M.E. Sluijter
}




\section{CERVICAL AREA}

Clinically three types of cervical pain syndromes can be distinguished:

a. Cervical pain: mechanical neck pain originating from the zygapophysial joints or from the disc (Aprill et al. 1990, 1992, Bogduk et al. 1993, Dwyer et al. 1990);

b. Cervicogenic headache: unilateral headache originating from the cervical spine (Sjaastad et al. 1983);

c. Cervicobrachial pain: pain originating from the cervical spine, with referral to a particular spinal segment.

Cervical pain may originate either from the zygapophysial joints or from one or more cervical discs (Aprill et al. 1990, Bogduk et al. 1993, Dwyer et al. 1990). No clinical criteria have been established to make a diagnosis of zygapophysial joint pain which is based on the patients history or on clinical examination.

Dwyer et al. (1990) performed a study on the pain pattern evoked by stimulation of cervical zygapophysial joints in volunteers. They found that stimulation of each joint by injection of hypertonic saline solution produced a clinically distinguishable characteristic pattern of pain. This radiation pattern in combination with paravertebral tenderness, by palpation over the joints may indicate zygapophysial pain (Sluijter and Mehta 1981, Sluijter et al. 1990, Vervest et al. 1991).

The condition can only be firmly diagnosed by the use of diagnostic zygapophysial joint blocks (Bogduk and Marsland 1988, Bogduk et al. 1993, Lord et al. 1995). In the study of Bogduk's et al. (1988) temporary pain relief was achieved in $68 \%$ of patients with a localized cervical pain, indicating that these joints can be an important source of pain.

The same authors (1993) determined the prevalence of disc and of zygapophysial joint pain in the same segment of post-traumatic cervical pain patients. In this group of patients they found that both structures play an equally important role in the pain syndrome. In $41 \%$ of patients the pain was emanating from both structures at the same time.

Clinical experience with cervical discography indicates that these structure can indeed be painful (Kikuchi et al. 1981). On physical examination one often finds midline tenderness in the cervical area facilitating identification of the nociceptive level. Painful disarders of the discs are not demonstrable by plain radiography, CTor MAI-scan. Provoked discography is a procedure in which a fine needle is introduced into an intervertebral disc, followed by an injection of contrast or of normal saline. If a disc is nociceptive, stressing the disc in this way will produce the patient's pain. Cervical pain may also be shown to originate from an intervertebral disc when a selective anaesthetization of the putative symptomatic intervertebral disc substantially relieves the patient's pain. 
Cervicogenic headache is, according to the current definition, a unilateral headache which is supposed to originate from the upper cervical region. Sjaastad et al. 1983) hypothetised the existence of this type of headache which he characterized as strictly unilateral attacks of headache which could be precipitated either by movements of by local pressure over the tender spots in the cervical area. Ipsilateral shoulder and arm pain is regularly seen together with a reduced range of motion in the cervical region.

Cervicogenic headache has to be differentiated from migraine without aura and from tension headache. The side locked unilaterality and the initiation of attacks in the cervical region is different from migraine. An important diagnostic criterium is that local anesthetic blockade of the segmental nerve C2 or C3 on the symptomatic side should abolish the pain of cervicogenic headache transiently. Lower segmental levels have been described as contributing to cervicogenic headache as well, but also the zygapophysial joints C2-C3 and C4-C5 (Bovim et al. 1992, Gawel and Rothbart 1992, Michler et al. 1991).

Cervicobrachial pain is localized in the mid- and lower cervical area with referral of pain into the shoulder and/or arm. The nociceptive source for this type of pain may be the dural sheath of the nerve root, the zygapophysial joints or the nerve fibres in the outer annulus. Nerve root pain may be caused by a prolapsed disc or by degenerative narrowing of the intervertebral foramen. Sometimes the pain may be caused by an irritation of the segmental nerve due the cervical segmental dysfunction (Merskey and Bogduk 1994, Sluijter 1990).

On physical examination one often finds a localized paravertebral tenderness over the cervical spine facilitating the search for the nociceptive segment. Sluijter (1990) suggested that characteristic tender points just anterior, over and posterior to the trapezius muscle border have a frequent but inconstant relationship with the segmental levels.

In nerve root pain due to narrowing of the intervertebral foramen neurological signs are usually absent, however, signs of secondary sympathetic involvement may be present.

An important diagnostic criterium to detect the segment which is involved in the pain syndrome is the result of diagnostic blocks with local anesthetic solution.

\section{Radiofrequency techniques on cervical level}

\section{Percutaneous facet denervation.}

For a facet denervation in the upper and middle cervical area the patient is positioned supine on the operating table. The C-arm is positioned slightly oblique so that the $\mathrm{X}$-rays are parallel to the axis of the intervertebral foramen which is upwards and slightly caudal. In this position of the $\mathrm{C}$-arm the segmental nerves exit parallel to the $\mathrm{X}$-rays. Since the electrodes will be introduced from posterolateral this projection will 
make it easy to monitor a safe distance between the electrode tip and the exiting segmental nerve.

The posterior primary ramus in this projection runs over the base of the superior articular process which is clearly visible (Fig. 1). Entry points are marked approximately $1 \mathrm{~cm}$ posterior to the posterior border of the facetal column and slightly caudal to the target point. A SluijterMetha Canula (SMK) C5 canula with a $4 \mathrm{~mm}$ active tip or alternatively a TOP XE 6 needle is introduced and carefully advanced anteriorly and cranially until contact is made with the facetal column at the target point. The position of the $\mathrm{C}$-arm is then changed to the antero-posterior (AP) direction. This should confirm the position of the tip of the needle adjacent to the "belt" of the spine at the corresponding level.

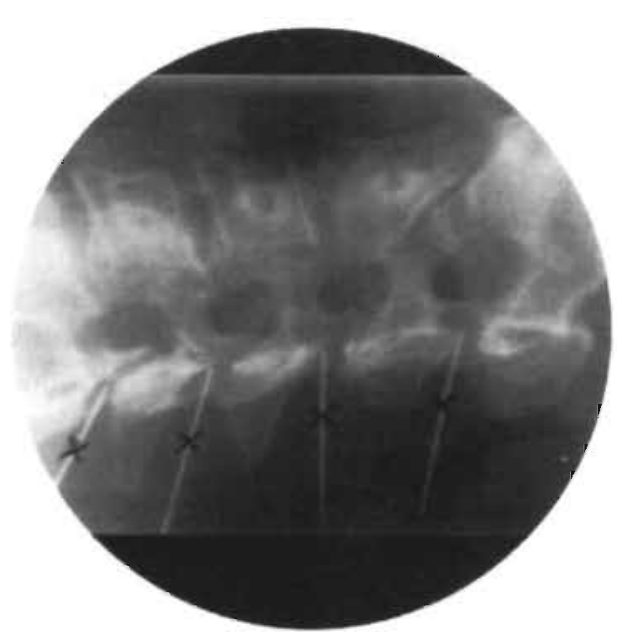

Figure 1. Cervical facet denervation: C-arm in $20^{\circ}$ oblique and $10^{\circ}$ caudocranial projection. Entry points on the skin marked with X. Needles make contact with bone at the base of the superior articular processes.

$50 \mathrm{~Hz}$ stimulation should now give a response at $\angle 1 \mathrm{~V}$. An $80^{\circ} \mathrm{C}$ lesion is made (when a TOP X'E needle is used $20 \mathrm{~V}$ is applied to the needle) for 60 seconds. This should heat the needle tip to the same temperature.

\section{RF-sympathetic block.}

The patient is on the operating table in a supine position. For a stellate ganglion block the cervicothoracic spine is visualised in an antero-posterior projection. The carotid artery is kept asicle while a SMK C5 canula with a $4 \mathrm{~mm}$ active tip is introguced to make contact with the $\mathrm{C} 7$ vertebral body just medial to the origin of the transverse process (Fig. 2A). The proper position is confirmed on an oblique projection (Fig. 2B). The electrode tip should lie anterior to the anterior border of the foramen. Two $\mathrm{ml}$ of contrast is injected to confirm the characteristic spread, followed by $2 \mathrm{ml}$ of $2 \%$ xylocain. A 60 seconds $80^{\circ} \mathrm{C}$ lesion is then made.

\section{Technique of RF-DRG.}

To perform the RF-DRG a conventional technique is used with the $\mathrm{C}$-arm positioned to have the X-rays parallel to the axis of the intervertebral foramen (Sluijter 1990). 


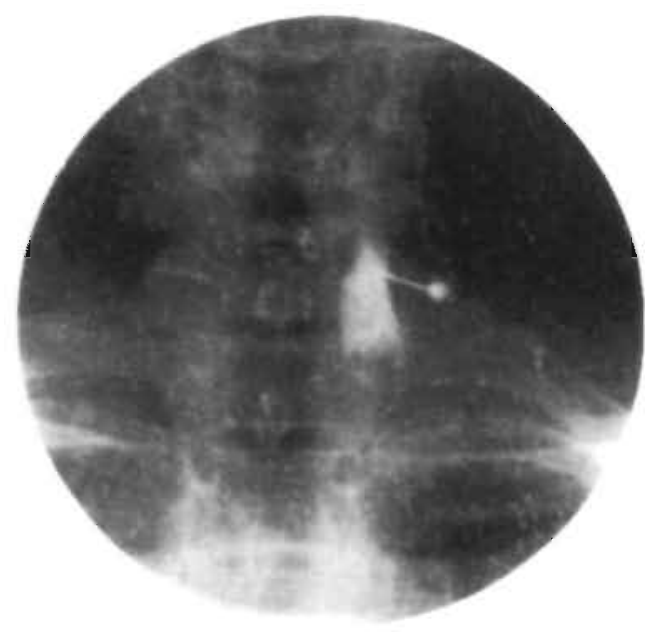

Figure 2A. Radiofrequency lesion of the stellate ganglion: AP projection. The electrode makes contact with the vertebral body (level C7) just medial to the origin of the transverse process.

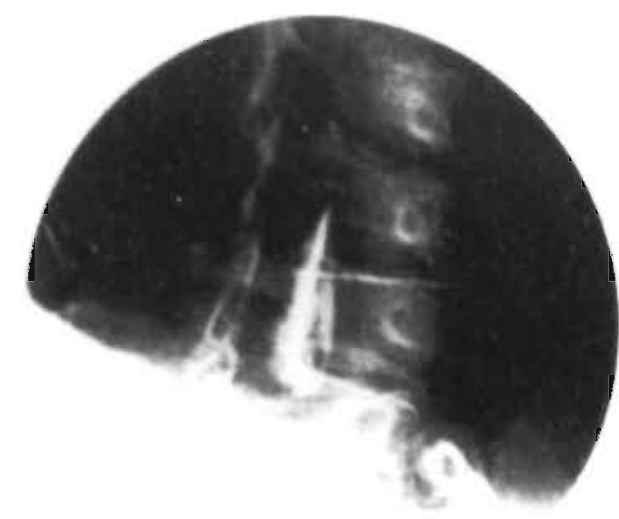

Figure 2B. Oblique projection: the electrode tip should lie anterior to the anterior border of the foramen.

This axis points $25-35^{\circ}$ anteriorly and $10^{\circ}$ caudally. With the $\mathrm{C}$-arm in this position, the entry point is found by projecting a metal ruler over the caudal part of the foramen.

The canula (Radionics SMK C5 with a 4 mm exposed tip) is introduced in the direction of the X-rays. If necessary the direction is corrected while the tip is still in the superficial layers, until the needle is projected on the screen as a dot (Fig. 3A).

In practice this dot should lie directly over the dorsal part of the intervertebral foramen at the transition between the middle and most caudal third part. This dorsall position is chosen in order to avoid possible damage to the motor-fibres of the segmental nerve and to the vertebral artery which runs anterior to the ventral part of the foramen. The direction of the X-rays is then changed to antero-posterior and the canula is further introduced until the tip is projected over the middle of the facetal column (Fig. 3B).

The stylet is now replaced by the radiofrequency (RF) probe. After checking the impedance, electrical stimulation is started at a rate of $50 \mathrm{~Hz}$. The patient should feel a tingling sensation at a voltage $>0.4 \mathrm{~V}$ and $<0.65 \mathrm{~V}$. Next the frequency is changed to $2 . \mathrm{Hz}$ and the patient is observed for muscle contractions. These should not occur below a voltage of 1.5 times the sensory threshold. 


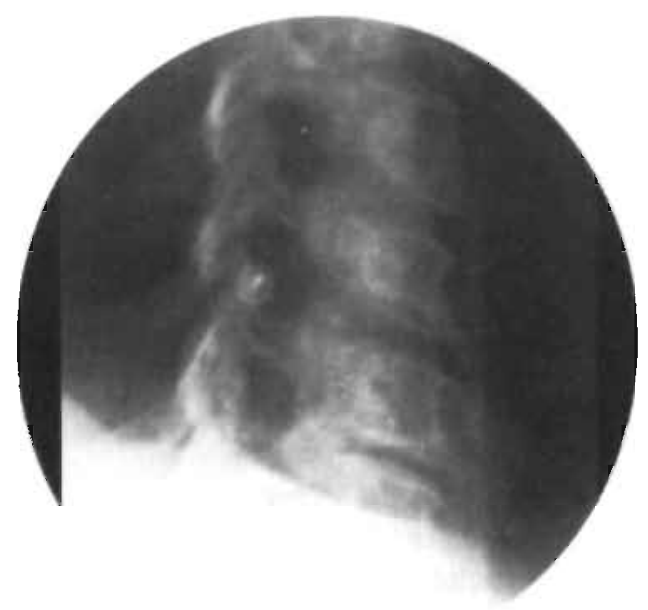

Figure 3A. Radiofrequency lesion adjacent to the dorsal root ganglion (RF-DRG), 20" oblique, 10 caudocranial projection. The needle is positioned in the posterior aspect of the foramen, at the junction of the middle and caudal third part. It is projected as a dot in funnel vision.

$0.5 \mathrm{ml}$ of contrast medium (omnipaque) is now injected to exclude an accidental intradural position of the electrode (Fig. 3C), and this is followed by $2 \mathrm{ml}$ of $2 \%$ lignocaine.

RF-current is then led through the electrode (Radionics RFG 3C lesion generator) in order to increase the temperature at the tip slowly to $67^{\circ} \mathrm{C}$. This temperature is maintained for 60 seconds.

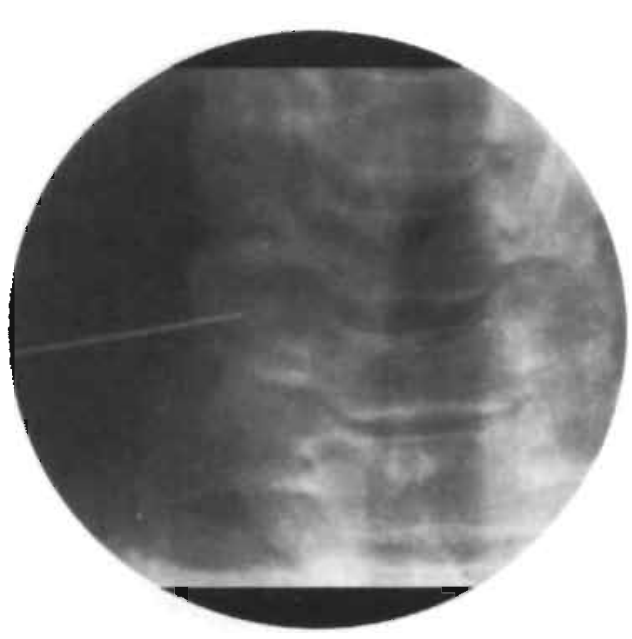

Figure 3B. RF-DRG: AP view. The tip of the needle is projected over the middle of the facetal column.

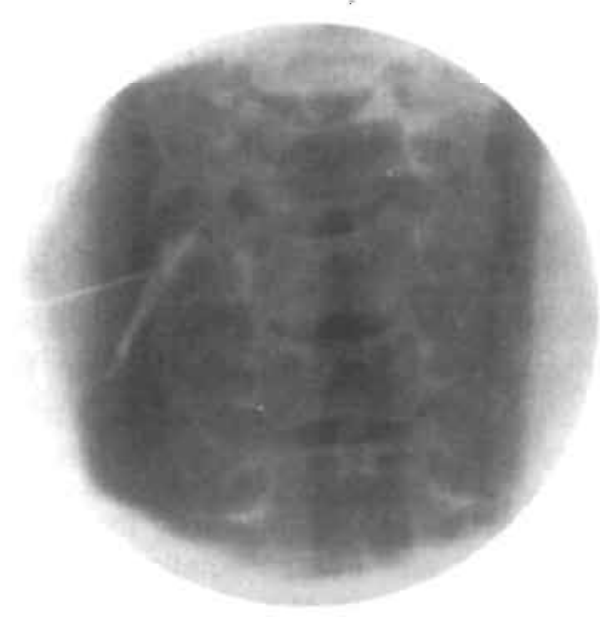

Figure 3C. AP view after injection of $0.5 \mathrm{ml}$ of omnipaque. 


\section{Efficacy of treatment}

There are three publications in literature evaluating the results of RF-lesioning in cervical spinal pain using $22 \mathrm{G}$ equipment.

Vervest and Stolker (1991) published a retrospective study performed in 53 patients with cervical pain radiating to head, shoulder or arm. Several RF-procedures were performed. If there was local tenderness over the facet joints a percutaneous cervical facet denervation was performed. If this was not successful and if there was cervical pain with referral to head or shoulder/arm diagnostic segmental nerve blocks were performed. Positive diagnostic blocks were followed by what the authors termed a percutaneous rhizotomy, a procedure which is identical to RF-DRG as described in this thesis. The results were good to excellent in $80.5 \%$ of treatments. The authors claimed that after a follow-up of 1.5 years, $84.6 \%$ of treated patients still had satisfactory pain relief.

Van Kleef et al. (1993) evaluated the effects and side effects of an RF-DRG in a prospective way. The results are published in this thesis.

Lord et al. (1995) performed an RF-lesion of the medial branch of the posterior primary ramus in order to evaluate the effect on pain in the higher and lower cervical region. Patients were selected by means of comparative local anesthetic blocks performed with two different local anesthetics on different occasions. The procedure was effective in the lower region in 7 out of 10 patients. Of the 10 patients who underwent third occipital neurotomy for treatment of C2-C3 zygapophysial joint pain, only 4 obtained long-lasting pain relief. Lord et al. used a posterior approach for the percutaneousi RF-neurotomy. They concluded that the encouraging results of lower cervical medial branch neurotomy justify a randomised, double-blind, controlled trial of this therapy.

Studies on the effect of RF-lesions in the treatment of cervicogenic headache are not available.

\section{THORACIC AREA}

The thoracic spine is the least common site for spinal complaints, it is the presenting symptom in $5 \%-10 \%$ of new patients visiting our pain clinic. Also in this group of patients diagnostic investigations are important to exclude underlying pathology such as herniations, aneurysms, tumours, old fractures or infections.

Clinically, two types of thoracic pain can be distinguished:

a. Thoracic pain: mechanical pain originating from the zygapophysial joints and/or thoracic disc (Merskey and Bogduk 1994, Stolker et al. 1993);

b. Thoracic segmental pain: thoracic pain with referral into one or more particular spinal segments due to involvement of the segmental nerve in the pain syndrome.

Thoracic pain may originate either from the zygapophysial joints or from the thoracic disc. 
As in the other spinal regions no criteria have been established whereby zygapophysial joint pain can be diagnosed on the basis of patients history or by physical examination. Pain emanating from the thoracic joints is usually related to degenerative processes, collaps of a vertebra or to postural abnormalities. Although clinical symptoms are not conclusive in this pain syndrome, the diagnosis of thoracic facet syndrome is in line with the diagnosis in the cervical and the lumbar region:

- Nearly continous uni- or bilateral pain in a localized area of the thoracic spine, without objective neurological signs;

- Paravertebral tenderness by palpation over the zygapophysial joints.

A transient relief of pain after a diagnostic medial branch block of the dorsal ramus of the segmental nerve may be used as a screening procedure to confirm the diagnosis.

In the study of Stolker et al. (1993) temporary pain relief was achieved in $51 \%$ of patients following a diagnostic block, indicating that these joints can be an important source of pain.

Thoracic discogenic pain can be diagnosed when a selective anaesthetization of the putatively symptomatic intervertebral disc completely relieves patient's pain for a short period.

Thoracic discography is hazardous because of the risk of a pneumothorax. No publications have formally described this procedure (Merskey and Bogduk 1994).

Thoracic segmentai pain suggests involvement of the segmental nerve. In most cases: the clinical diagnosis is unclear and made by exclusion. Diagnoses such as segmental peripheral neuralgia, slipping rib syndrome and twelfth rib syndrome are frequently encountered in this group of patients. Sometimes the pain is due to a collaps of a vertebra as a result of trauma or osteoporosis. On physical examination one sometimes finds a localized pain over the thoracic spine facilitating the search for the nociceptive level. In case of rib involvement (twelfth rib syndrome, slipping rib syndrome) one finds sharp local pain on palpation over the rib (Merskey and Bogduk 1994).

The segment involved can be identified by means of two or more diagnostic: segmental nerve blocks performed at different levels. This is because thoracic segmental pain tends to overlap from one segment to another. The level which provides the best temporary response on pain relief is selected for RF-lesioning.

\section{Radiofrequency techniques on thoracic level}

\section{Technique of RF-DRG}

For an RF-DFG below the level of $\mathrm{T} 7$ the following technique is used. A $100 \mathrm{~mm}$ canula (Radionics SMK 22G, $5 \mathrm{~mm}$ active tip) is inserted $1 \mathrm{~cm}$ medial to the angle of 


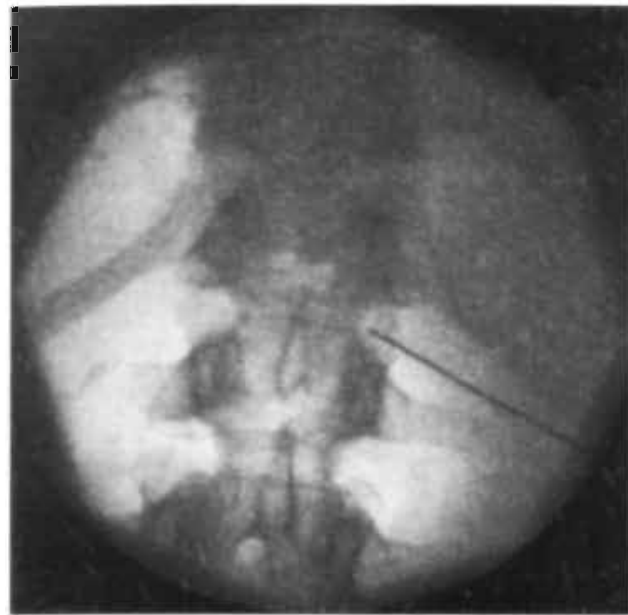

Figure 4A. Fluoroscopic images of an RF-DRG at level Th12. C-arm in AP position. The canula is introduced until the tip is projected over the middle of the facetal column.

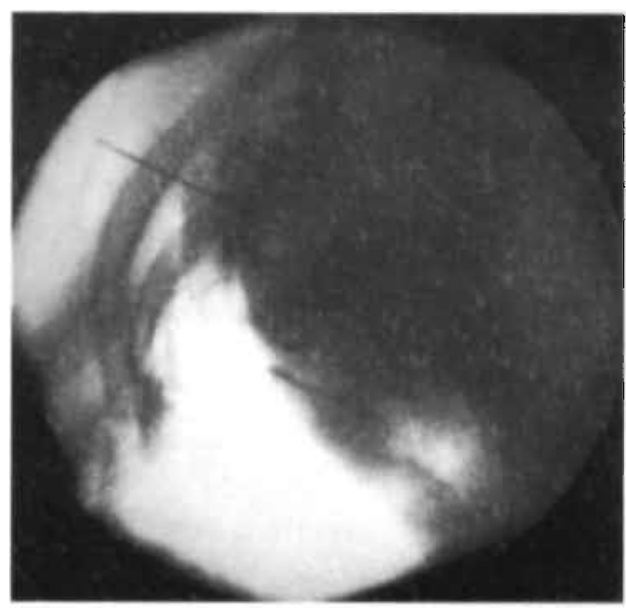

Figure 4B. C-arm in lateral position. The tip of the canula in the posterior part of the intervertebral foramen.

the ribs. It is carefully advanced at an angle parallel to the ribs until it is placed in the

cranio-dorsal part of the intervertebral foramen (Figs. 4A and 4B). The stylet of the canula is replaced with an RF-probe and sensory stimulation is carried out at $50 \mathrm{~Hz}$. Correct positioning is confirmed when the patients perceives a tingling sensation in the selected dermatome using a 0.4-1 V stimulus.

Stimulation is then performed at $2 \mathrm{~Hz}$. If the needle point is too close to the anterior root the muscles contract at a stimulation threshold below 1.5 times the sensory threshold. After satisfactory placement is achieved, contrast medium $(0.4 \mathrm{ml}$ omnipaque) is injected to exclude intradural or intravascular spread. This is followed by $2 \mathrm{ml}$ of $2 \%$ lignocaine, which provided analgesia of the dorsal root ganglion. A 60 seconds $67^{\circ} \mathrm{C}$ lesion is made by using an RF-lesion generator system (Radionics RFG 3C) with a thermocouple electrode for continuous temperature measurement.

For an RF-DRG at T7 anci above a different technique is used (Sluijter et al. 1991). Above $T 8$ the anatomy of the origin of the transverse process prevents accurate needie positioning. To overcome this problem, under fluoroscopic control, a small hole is drilled with an $\mathrm{AO}$ pneumatic drill through the lamina of the vertebra using a 16G Kirschner wire to gain access to the intervertebral foramen. A 20G SMK 15 canula is then inserted (Figs. 5A and 5B). Electrical stimulation and following steps is then carried out as described above. 


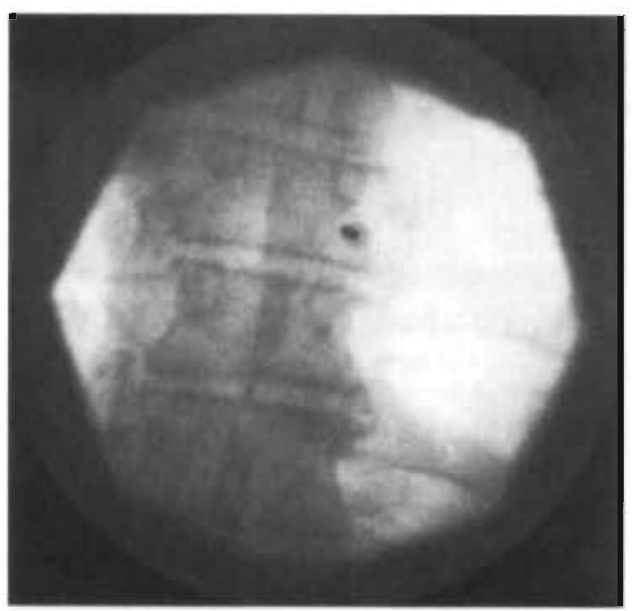

Figure 5A. Fluoroscopic images of an RF-DRG at level Th7. C-arm in AP position. The canula is projected on the screen as a dot.

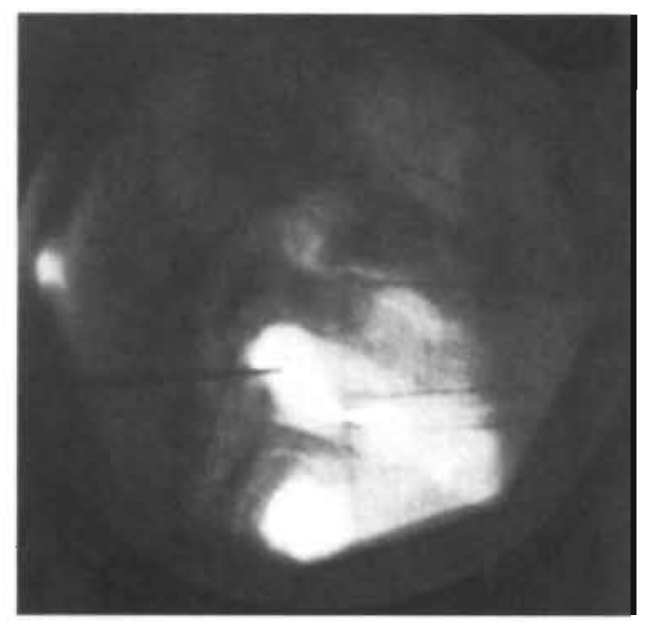

Figure 5B. C-arm in lateral position.

\section{Technique of Percutaneous Facet Denervation}

A facet denervation is usually performed at 3 or 4 leveis since each facet joint is considered to be innervated by 2 medial branches. The patient lies in the prone position on an operating table. Under fluoroscopic control with a C-arm image intensifier in the antero-posterior position a 22G canula (Sluijter-Mehta canula 100.5, active tip $5 \mathrm{~mm}$ ) or a $100 \mathrm{~mm}$ TOP XE electrode is inserted. The canula is advanced until there is bone contact at the junction of the superior articular process and the transverse process. The $\mathrm{C}$-arm is turned to the transverse position in order to check the depth of the canula. The Sluijter-Mehta Kit TC 10 RF-probe (Radionics) is inserted in the canula and the proper localization is confirmed by electrical stimulation. A 50 $\mathrm{Hz}$ current with a voltage of less than $1 \mathrm{~V}$ should elicit a tingling sensation paravertebrally. Motor stimulation with $2 \mathrm{~Hz}$ and a voltage of $1 \mathrm{~V}$, or less, should provoke paravertebral muscle contractions. When these criteria are met, $0.3-0.5 \mathrm{ml}$ lidocaine $2 \%$ is administered through the canula and a lesion is made at a temperature of $80^{\circ}$ $\mathrm{C}$ for 60 seconds (lesion generator RFG-3C, Raciionics).

\section{Efficacy of treatment}

There are only a few publications in the literature evaluating the results of RF-procedures in the thoracic area, using 22G RF-equipment. 
Stolker et al. (1993) performed a percutaneous facet denervation in 40 patients with chronic thoracic pain. All patients had a transient positive respons ( $>50 \%$ pain relief) after a diagnostic nerve block and were considered to have chronic thoracic facet pain.

Two months after the procedure $82.5 \%$ of patients had $>50 \%$ pain relief. The author claims a long term pain relief (average follow-up 31 months) of $83 \%$. The long term follow-up was performed in 36 patients.

Stolker et al. (1994) also performed a study in patients with chronic thoracic segmental pain. Forty-five patients were selected for a posterior thoracic percutaneous rhizotomy (PPR).

All patients had a temporary positive response to an intercostal block with lignocaine. Two months after the procedure $91.1 \%$ of patients claimed more than $50 \%$ improvement.

After a follow-up period of 13-46 months (median 24 months) results were evaluated in 41 patients: five had undergone reintervention. Good results were achieved in $85 \%$. of patients.

Van Kleef et al. (1995) evaluated the effects of an RF-lesion of the dorsal root ganglion in patients with thoracic segmental pain. The results are published in this thesis.

\section{LUMBAR AREA}

The lumbar spine is the most common site for chronic spinal pain and is the presenting symptom of $45 \%$ of patients visiting our pain clinic. Clinically, two types of lumbar pain can be distinguished once serious pathology has been excluded (Waddell et al. 1982):

a. Mechanical low back pain with pain mainly emanating from one of the components of the three-joint complex;

b. Low back pain with irradiation in the leg due to nerve root involvement.

Mechanical back pain originates from one of the components of the 3-joint complex, i.e. from the disc or from the posterior joints. The role of the facet joints as a source of pain has been the subject of some debate. Kuslich et al. (1991) studied the effect of mechanical stimulation of various structures in patients who underwent a laminectomy for a prolapsed disc under local anaesthesia. They found that the outer part of the anulus fibrosus and the posterior longitudinal ligament were invariably painful but that stimulation of the facetal joints produced only mild pain in a minority of patients. Their findings may however have been influenced by the selection of patients, who all had radicular rather than mechanical pain.

Several other authors regard the facet joint as a common source of pain (Bogduk and Long 1980, Lilius et al. 1989, Marks et al. 1992, Shealy 1975, Shealy 1976, Sluijter and Mehta 1981). Facet joint pain may be referred to the buttock and to the thigh (Marks 1989, Mooney and Robertson 1976). There is often pain on hyperextension and the pain may be provoked by sudden movements. Paravertebral tenderness is. 
common but this is an aspecific finding and it may be masked by tension of the overlying muscles.

No criteria have been established whereby lumbar zygapophysial joint pain can be diagnosed on the basis of the patient's history or of conventional clinical examination. Local anesthetic blockade of the nerve supply of the joint or an intra-articular injection of the putative symptomatic joint can confirm the diagnosis (Bogduk and Marsland 1988, Marks et al. 1992, Mooney and Robertson 1976).

In a retrospective study, North et al. (1994) found that in a group of 82 low back pain patients 42 patients reported temporary pain relief after a diagnostic medial brach posterior primary ramus block. After RF-lesioning of the branch they concluded, however, that these diagnostic blocks may lack specificity in predicting long-term response to denervation.

The lumbar disc is considered to be a source of lumbar pain. In this pain syndrome, disruption of the disc and leakage of the nucleus pulposus material into the annulus fibrosus is believed to be a source of pain (Crock 1986, Jaffray and O'Brien 1986). The question whether degeneration of a disc is painful remains unsolved. Friedenberg and Miller (1963) did not find any correlation between disc pain and degeneration of the disc. Van Haranta et al. (1987) on the other hand stated that especially in patients with a deterioration of the disc provocation discography was positive. In the vast majority of patients a positive response to a prognostic block correlates with some degree of degeneration of the disc, varying from slight to severe.

On physical examination disc pain may give midline tenderness on palpation and there may be an increase of pain on flexion rather than on extension. Many patients with disc pain find it painful to deflect and do so in a curious, biphasic manner. If there is lateralisation during this manoeuvre this is called a corkscrew phenomenon.

Nerve root pain is characterised by dermatomal spread, usually well into the lower leg and often into the foot. In many patients there is loss of neve function to a variable degree and there may be signs of sympathetic overactivity (Pernak 1988).

\section{Radiofrequency lesions in the lumbar area}

\section{Percutaneous facet denervation.}

With the patient prone on the operating table, the C-arm is positioned in a slightly (10-15) oblique projection until the grooves between the superior articular and transverse processes are clearly visualised. Entry points are marked overlying the grooves at the L4, L5 and S1 level. In these grooves run the posterior primary rami of L3, L4 and L5. Another entry point is marked overlying the S1 foramen.

An SMK C10 canula with a $5 \mathrm{~mm}$ active tip is introduced in each entry point. The upper three electrodes are positioned under tunnel vision until the tip lies in the groove (Fig. 6A). The lowest electrode is introduced slightly upwards until contact is made 

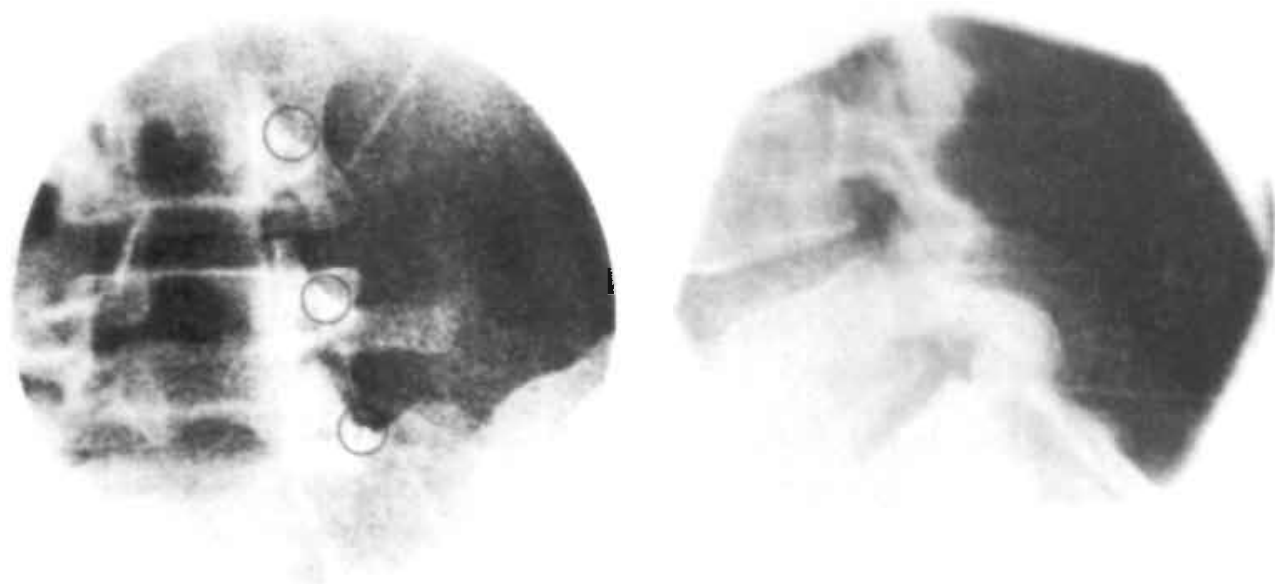

Figure 6A. Lumbosacral facet denervation. C-arm in $5^{n}$ oblique projection. Needies in position for the posterior primary rami L3, L.4 and L5. Needles projected as a dot (within circles).
Figure 6B. Transverse projection Needles tip should be posterior (of the posterior part of the foramen)

with bone just distal to the articular space.

This electrode should lesion the communicating nerve which runs cranially from the S1 foramen.

The proper position of the electrodes should always be checked on the transverse projection (Fig. 6B). This is essential to prevent damage to the segmental nerves. 50 $\mathrm{Hz}$ stimulation should give a response below $1 \mathrm{~V}$. A 60 seconds $80^{\circ} \mathrm{C}$ lesion is made.

\section{RF-sympathetic block.}

This block is usually performed at the L3 and L4-level. With the patient prone on the operating table the $\mathrm{C}$-arm is positioned in an oblique direction so that the spinous processes are projected over the facetal joint column of the opposite side. An entry point is selected overlying the side of the vertebral body at the junction of the lower and middle third of the vertebra. A 20G SMK C15 canula with a $10 \mathrm{~mm}$ active tip is introduced under tunnel vision (Fig. 7A). It is carefully advanced, passing cranial to the segmental nerve and avoiding contact with the periosteum of the vertebral body.

The position is then checked on the tranverse and antero-posterior projections (Fig. 7B). The tip should lie in level with the anterior margin of the vertebra and just medial to the middle of the facetal column. This is important to avoid damage to the 


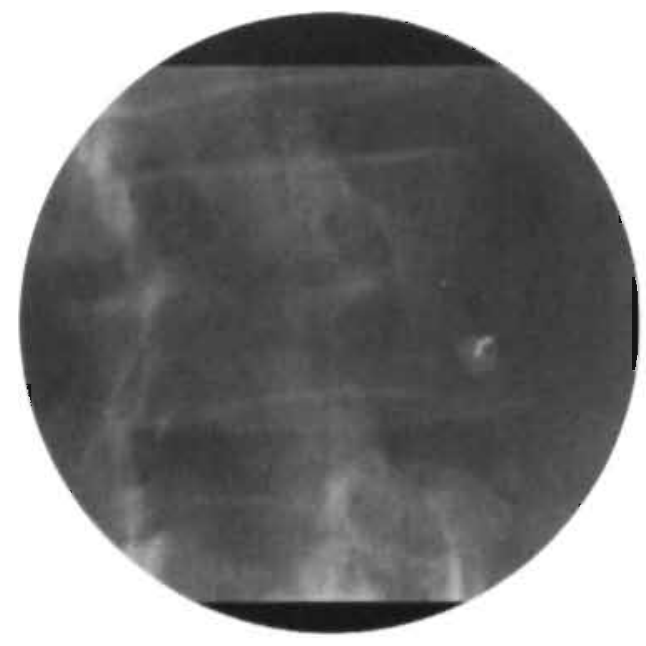

Figure 7A. AF-sympathetic chain L4, 25" oblique projection. The electrode passes cranial to $L 4$ nerve. Electrode projection in tunnel vision avoids contact with periosteum.

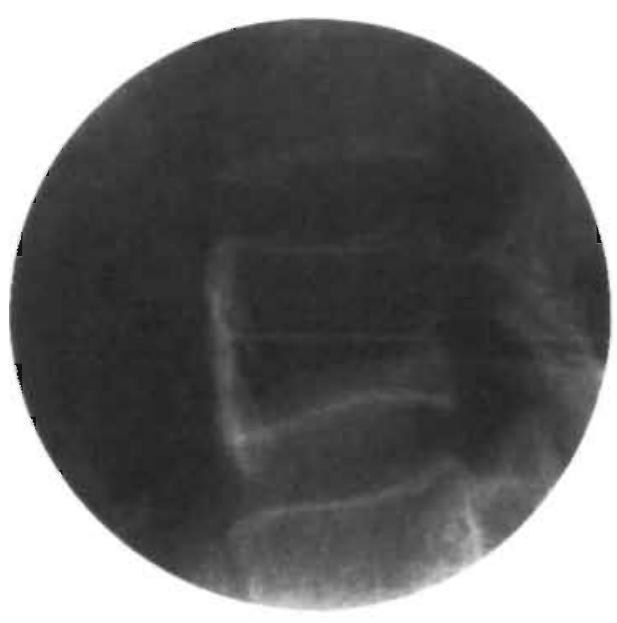

Figure 7B. AF-sympathetic chain lateral view.

ilioinguinal nerve. Injection of contrast should show the typical spread of contrast. 2 $\mathrm{ml}$ of $2 \%$ lignocaine are then injected and a 60 seconds $80^{\circ} \mathrm{C}$ lesion is made.

\section{RF-disc lesion.}

With the patient prone on the operating table the $\mathrm{C}$-arm is adjusted in an approximately $45^{\circ}$ oblique projection. The position is then further adjusted along the horizontal axis until there are no more double contours in the endplates. For L5-S1 this may result in considerable obliqueness in two planes.

An entry point is marked overlying the middle of the disc just lateral to the facet joint. A 20G SMK C15 canula with a 10 or $15 \mathrm{~mm}$ tip is introcluced using tunnel vision (Fig. $8 \mathrm{~A})$. It is important that the canula is directed as far medial as possible since this ensures passage medial to the exiting segmental nerve. The canula should be advanced very slowly when it is in the vicinity of this nerve. If the patient reports paresthesiae the direction should be adjusted very slightly medially and caudally. injection of local anaesthetic solution at this stage is not recommended in order to avoid mechanical damage to the exiting nerve which might then go unnoticed. 


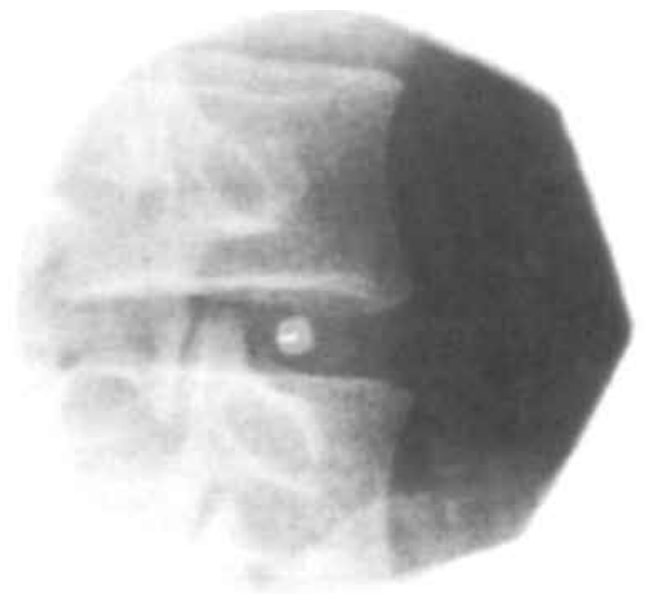

Figure 8A. RF-disc lesion. $45^{*}$ oblique projection Needle as a dot on the screen (tunnel vision).

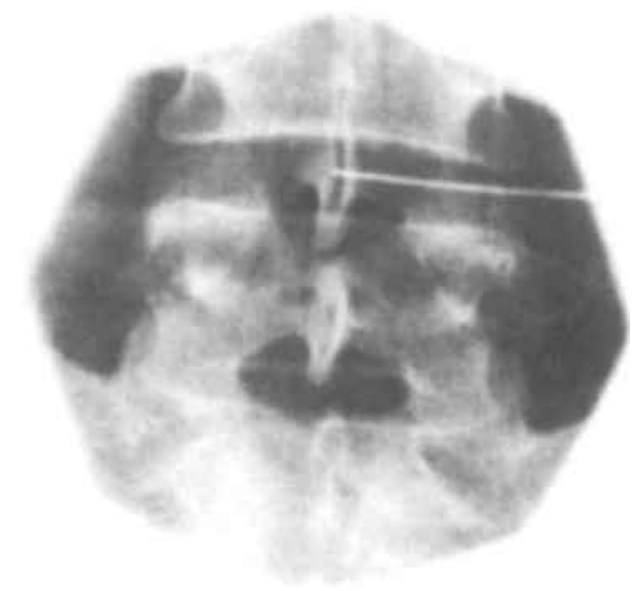

Figure 8B. AF-disc. AP view. Canula in center of the disc.

On entering the disc there is a characteristic loss of resistance. Continuous impedance monitoring confirms the correct position by a marked fall in impedance at this stage. The projection is then checked on the tranverse and antero-posterior projections and the canula is advanced until the tip lies in the centre of the disc (Fig. $8 \mathrm{~B})$. At the L5-S1 level this is not always possible if there is a high iliac crest. A concession then has to be made but the tip of the canula should at least lie medial to the facetal column.

Stimulation at 2 and $50 \mathrm{~Hz}$ should not give a response below $2 \mathrm{~V}$. A 180 seconds $75^{\circ}$ $\mathrm{C}$ lesion is made. The tip temperature is monitored for 30 seconds after completing the lesion. It usually falls to $52-55^{\circ} \mathrm{C}$ over that period.

The technique for prognostic disc injections is identical. A 22G SMK C15 can be used to minimise discomfort. When the needle is in position a mixture of $2 \mathrm{ml} \%$ lignocaine and $1 \mathrm{ml}$ of contrast medium (omnipaque) is injected. If there is overflow of solution into the epidural space the patient should rest in bed until the effects of the lignocaine have worn off.

\section{RF-lesion of the communicating ramus.}

With the patient prone on the operating table the C-arm is adjusted as for a sympathetic block (Sluijter 1989). An entry point is selected overlying the lateral part of the vertebral body just caudal to the transverse process. A SMK C15 canula with 


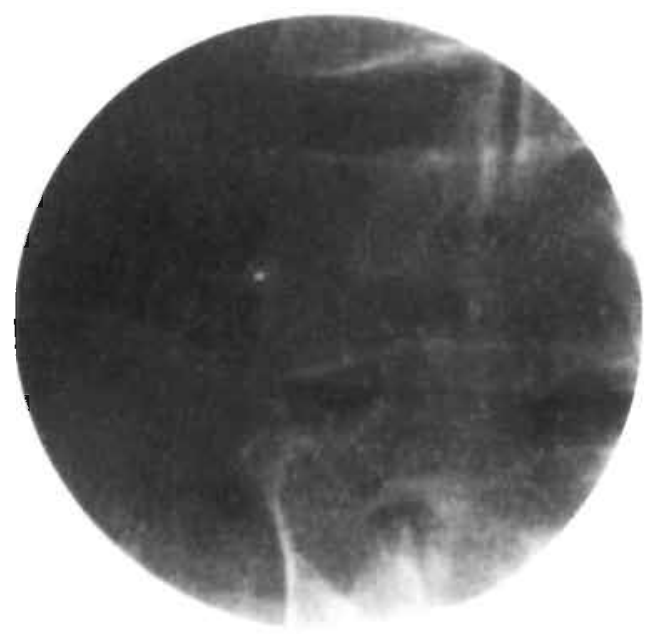

Figure 9A. AF-lesion of the communicating ramus. 25 " oblique projection. Contact with posterolatera! aspect of the vertebral body, just caudal to the transverse process.

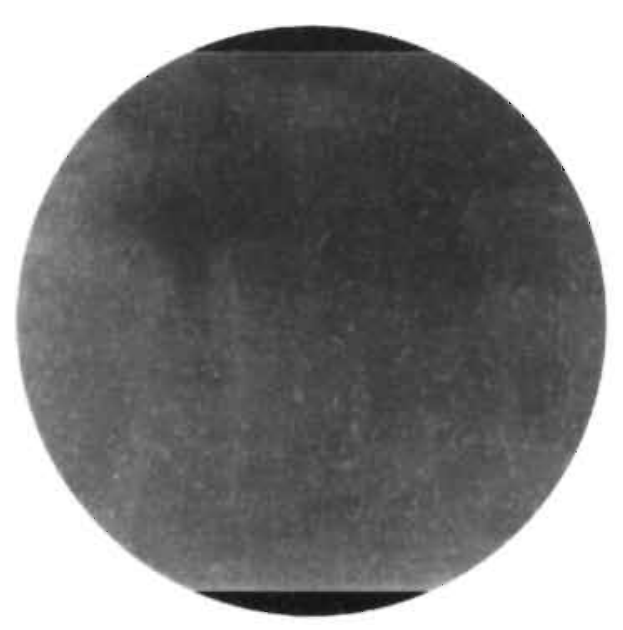

Figure 9B. Lateral view. The tip of the electrode just posterior of the middle of the vertebral body.

a $2 \mathrm{~mm}$ active tip is introduced under tunnel vision until it makes contact with bone at the described point (Fig. 9A). The position is checked in the lateral projection, which should show the tip of the electrode lying somewhat posterior to the middle of the vertebral body (Fig. 98).

Electrical stimulation at $50 \mathrm{~Hz}$ should elicit a sensation in the back at a voltage $<1.5$ $\mathrm{V}$. There should be no motor response to $2 \mathrm{~Hz}$ stimulation at $2 \mathrm{~V}$. If these conditions are not met the electrode is carefully manipulated both in the sagittal and in the transverse plane to find a better position. A 60 seconds $80^{\circ} \mathrm{C}$ lesion is then made.

\section{Technique of RF-DRG.}

With the patient prone on the operating table the $\mathrm{C}$-arm is positioned in the anteroposterior direction. A SMK C $C_{1} 10$ canula with a $5 \mathrm{~mm}$ active tip is introduced at an entry point $8 \mathrm{~cm}$ from the midline and $4 \mathrm{~cm}$ caudal to the relevant transverse process. The electrode is carefully advanced to make contact with the junction of the lower border of the tranverse process and the lamina. It is then manipulated slightly caudally and anteriorly until it slips into the craniodorsal part of the foramen. It is advanced until the tip is projected over the middle of the facetal column. Next the posterior position in the foramen is confirmed on the transverse projection. The stylet is now replaced. 
by an RF-probe. After checking the impedance electrical stimulation is started at 50 $\mathrm{Hz}$. The patient should feel a tingling sensation at a voltage between 0.4 and $0.65 \mathrm{~V}$. Next the frequency is changed to $2 \mathrm{~Hz}$ and the patient is observed for muscle contractions. These should not occur below a voltage of $1.5 \times$ the sensory threshold. $0.5 \mathrm{ml}$ of contrast medium (omnipaque) is now injected in order to exclude an accidental intradural position of the electrode, and this is followed by $2 \mathrm{ml} 2 \%$ lignocaine.

RF-current is then led through the electrode (Radionics RFG 3C) in order the increase the temperature at the tip to $67^{\circ} \mathrm{C}$. This temperature is maintained for 60 seconds.

For L5 the approach may be more difficult due to the iliac crest. The utilisation of tunnel vision is then preferable. The dorsal root ganglion of S1 cannot be reached with a straight instrument. For an RF-DRG at this level a small hole has to be drilled with a Kirschner wire into the dorsal aspect of the sacrum.

\section{Efficacy of treatment}

There are several reports on the results of RF-lesioning in spinal lumbar pain, using $22 \mathrm{G}$ equipment.

RF-lesioning of medial branch of the posterior primary ramus of the segmental nerve was studied in a retrospective way by North et al. (1994). Of the 42 patients who underwent RF-treatment, $45 \%$ reported at least $50 \%$ pain relief two years after treatment or at the last follow-up. This relief of pain was associated with an improvement in most activities in the patients' daily life.

The first prospective controlled double-blind randomised study to assess the efficacy of RF-facet joint denervation was conducted by Gallagher et al. (1994). After diagnostic blocks 41 patients were randomised as they entered the study to undergo either RF-facet joint denervation or a placebo procedure, which was identical in every way apart from the heat lesion. The study showed a significant improvement in pain scores following denervation at 1 and 6 months when compared with the placebo group.

The first pilot study of the effect of an RF-disc procedure was published by Van Kleef et al. (1995). A total of 129 diagnostic discographies were performed in 77 patients to select 39 patients for an RF-disc procedure. Twenty unoperated patients and 19 operated patients were treated with this new technique. There was improvement of two points on a four point scale in $70 \%$ of the unoperated patients and in $37 \%$ of the operated patients, eight weeks after treatment. At the end of the follow-up (mean 16 months) these figures were $55 \%$ and $27 \%$.

A prospective study the evaluate the efficacy of the method is in progress. 


\section{REFERENCES}

1. Aprill C, Bogduk N. The prevalence of cervical zygapophysial joint pain. Spine 17:744-747, 1992.

2. Aprill C, Dwyer S, Bogduk N. Cervical zygapophysial joint pain patterns II: a clinical evaluation. Spine 15:458-61, 1990.

3. Bogduk N, Aprill C. On the nature of neck pain, discography and cervical zygapophysial joint blocks. Pain 54:213-217, 1993.

4. Bogduk N. Long DM. Percutaneous lumbar medial branch neurotomy, ai modification of facet denervation. Spine 5:192-200, 1980.

5. Bogduk N, Marsland A. The cervical zygapophysial joints as a source of neck pain. Spine 13:610-617, 1988.

6. Bovim G, Berg R, Dale LG. Cervicogenic headache: anesthetic blockades of cervical nerves (C2-C5) and facet joint (C2-C3). Pain 49:315-320, 1992.

7. Crock HV. Internal disc disruption a challenge to disc prolaps 50 years on. Spine 11:650-653, 1986 .

8. Dwyer A, Aprill C, Bogduk N. Cervical zygapophysial joint pain patterns I: a study in normal volunteers. Spine 15:453-457, 1990.

9. Friedenberg ZB, Miller WT. Degenerative disc disease of cervical spine. J Bone Joint Surg 45A:1171. $1178,1963$.

10. Gallagher J. Petricciore PL. Wedley JR et al. Radiofrequency facet joint denervation in the treatment of low back pain: a prospective controlled double-blind study to assess its efficacy. The Pain Clinic 7:193-198, 1994

11. Gawel MJ. Rothbart PJ. Occipital nerve block in the management of headache and cervical pain. Cephalalgia 12:9-13, 1992.

12. Jaffray D, O'Brien JP: Isolated intervertebral disc resorption. A source of mechanical and inflammatory back pain? Spine 11:397-401, 1986.

13. Kikuchı S, MacNab I, Moreau P. Localisation of the level of symptomatic cervical disc degeneration. J Bone Joint Surg 63:272-277, 1981.

14. Kustich S, Ulstrom CL, Michael CJ. The tissue origin of low back pain and sciatica. Orthopedic Clinics of North America 22:181-187, 1991.

15. Lilius. G. Laasonen EM, Myllynen P. Harilainen A, Grönland G. Lumbar facet joint syndrome. J Bone Joint Surg 71B:681-684, 1989

16. Lord SM, Barnsley L, Bogduk N. Percutaneous radiofrequency neurotomy in the treatment of cervical. zygapophysial joint pain (a caution). Neurosurgery 36:732-739, 1995.

17. Marks RC. Distribution of pain provoked from lumbar facet joints and related structures during diagnostic spinal infiltiation. Pain 39:37-40, 1989.

18. Marks RC. Houston T. Thulbourne T. Facet joint injection and facet nerve block: a randomised. comparison in 86 patients with chronic low back pain. Pain 49:325-328, 1992.

19. Merskey and Bogduk N. Classification of chronic pain. International Association of the Study of Pain, 1994.

20. Michler RP. Bovim G, Sjaastad O. Disorders in the lower cervical spine. A cause of unilateral headache? Headache 31:550-551, 1991.

21. Mooney V, Robertson J. The facet syndrome: Clin Orthop 115:149-156, 1976.

22. North RB, Ham M. Zahurak M, Kidd DH. Radiofrequency lumbar facet denervation: analysis of prognostic factors. Pain 57:77-83, 1994.

23. Pernak J. Percutaneous radiofrequency thermal lumbar sympathectomy and its clinical use. Eburon Delft. Thesis 1988

24. Shealy CN. Facet denervation in the management of back and sciatic pain. Clin Orthop 115:157-164. 1976.

25. Shealy $\mathrm{CN}$. Percutaneous radiofrequency denervation of spinal facets. Treatment for chronic back pain and sciatica. J Neurosurg 43:448-451, 1975 
26. Sjaastad O. Saunte C, Howdahl H, Breivik H, Gronbaek E. Cervicogenic headache. An hypothesis. Cephalaigia, 3:249-256, 1983.

27. Sluiter ME. Radiofrequency lesions of the communicating ramus in the treatment of low back pain, in Racz GB (ed.): Techniques of neurolysis, Boston, Kluwer Academic Publishers 1989, pp 145-160.

28. Sluijter ME. Radiotrequency lesions in the treatment of cervical pain syndromes. Burlington, Radionics 1990, pp 1-19.

29. Sluijter ME, Dingemans WAAM, Barendse GAM, Van Kleet M. Comment on 'Ischaemic spinal cord lesion following percutaneous radiofrequency spinal thizotomy'. Pain 47:241, 1991.

30. Sluijter ME, Mehta M. Treatment of chronic back and neck pain by percutaneous thermal lesions, in Lipton S (ed.): Persistant pain, modern methods of treatment, London: Academic Press, vol. 3, chapter 8, 1981, pp 141-179.

31. Stolker RJ, Vervest ACM, Groen GJ. Percutaneous facet denervation in chronic thoracic spinal pain. Acta Neurosurg 122:82-90, 1993.

32. Stolker RJ, Vervest ACM, Groen GJ. The treatment of chronic thoracic segmental pain by radiofrequency percutaneous partial rhizotomy. J Neurosurg 80:986-992, 1994.

33. Van Haranta H, Sachs BL, Spivey MA, Gayer RD, Hochschuler SH, Rashbaum RF, Johnson RG. Ohnmeiss D, Mooney V. The relationship of pain provocation to lumbar disc detoriation as seen by CT/discography. Spine 12:295-298, 1987.

34. Van Kleef M, Spaans F, Dingemans W, Barendse GAM, Floor A, Sluijter ME. Effects and side effects of a percutaneous thermal lesion of the dorsal root ganglion in patients with cervical pain syndrome. Pain 52:49-53, 1993.

35. Van Kleef M, Barendse GAM, Dingemans WAAM, Wingen C, Lousberg R, De Lange S, Sluijter ME. Effects of producing a radiofrequency lesion adjacent to the dorsal root ganglion in patients with thoracic segmental pain. Clin J Pain 11:325-332, 1995.

36. Van Kleef M, Barendse GAM, Lousberg R, Van Suijlekom JA, Dingemans WAAM, Bulstra SK, Sluijter $M E$. Eerste klinische ervaringen met radiofrequente laesie van de discus intervertebralis bij patiênten met lage rugklachten. Ned Tijd Pijn. Pijnbestrijding 15:13-17, 1995.

37. Vervest ACM, Stolker RJ. The treatment of cervical pain syndromes with radiofrequency procedures. Pain Clin 4:103-112, 1991.

38. Waddell G, Main CJ, Morris EW, Venner RM, Rae PS, Sharmy SH, Galloway H. Normality and reliability in the clinical assessment of backache. Br Med J 284:1519-1523, 1982. 
CHAPTER 5

Morphological effects of radiofrequency lesions on the dorsal root ganglion (RF-DRG) An experimental study in the goat
M. van Kleef
G. Freling
M.J.H.M. Herpers
M.E. Sluijter
S. de Lange
J.W. Arends 


\section{ABSTRACT}

Radiofrequency (RF) lesions adjacent to the dorsal root ganglion (DRG) are increasingly used in the treatment of intractable chronic pain of spinal origin. Opinions differ on which nerve fibres are affected by these lesions. Morphological studies have been done to assess the effects of RF-lesions on nervous tissue. Interpretation has been difficult, since most studies were performed under circumstances not comparable to clinical situations.

This study was undertaken to investigate morphological effects of RF-lesions as they are made in the normal clinical situation. To this end, RF-DRG lesions were produced in goats using identical electrodes and parameters. In two goats 22 G $100 \mathrm{~mm}$ SMK. electrodes with a $5 \mathrm{~mm}$ active tip were positioned posterior to the lumbar dorsal root ganglia (DRG) using fluoroscopic control. 60 seconds $67^{\circ} \mathrm{C}$ lesions were made on one side. On the other side electrodes were introduced but no RF-lesion was made. The goats were sacrificed two weeks after the procedure. The lesions were studied for size as well as for effects on proliferation and regeneration using monoclonal antibodies agairst recombinant parts of the Ki-67 antigen (MIB-1).

Lesions made inside the DRG (2x) were $1.8-2.0 \mathrm{~mm}$ in size. In these lesions there was a total loss of myelinated fibres. In lesions made adjacent to the DRG there was: a significantly higher MIB-1 labeling on the treated side as compared to the shamtreated side.

In conclusion an RF-lesion inside the DRG destroys myelinated fibres. A lesion adjacent to the DRG increases MIB-1 activity, indicating proliferation and regeneration. despite the fact that the lesion is situated outside the ganglion. 


\section{INTRODUCTION}

Radiofrequency lesions of the dorsal root ganglion (RF-DRG) have been increasingly used in the treatment of intractable chronic cervical and thoracic pain of spinal origin (Nash 1986, Stolker et al. 1993, Vervest and Stolker 1991). Accumulated clinical experience with this method has shown it is possible to alleviate pain without clinical signs of nerve damage (Van Kleef et al. 1993).

Based on physiological studies, it has been suggested that these clinical effects might be due to a higher sensitivity to heat of small myelinated fibres (Letcher and Goldring 1968). On the other hand some histological studies reveal indiscriminate destruction of both small and large fibres following RF-lesions (Smith et al. 1981, Uematsu 1977). These studies however were performed with $14 \mathrm{G}$ electrodes which were placed by open surgery close to the dorsal root ganglion. These have been replaced by $22 \mathrm{G}$ electrodes which allow a more discrete lesion to be made.

In case of RF-DRG, the aim is to make a partial and - preferably selective - interruption of the afferent nerve conduction. Therefore, the lesion should be made on the posterior side of the ganglion at a safe distance from the motor fibres, but in the vicinity of the afferent fibres.

This study was undertaken to study the effect of an RF-lesion both inside and adjacent to the DRG. Nerve lesions were studied according to their macroscopic size as well as $\mathrm{Ki}-67$ expression, as a proliferative parameter reflecting regenerative activity of nerve tissue, following damage (Cathoretti et al. 1992).

\section{Materials and methods}

Animal studies were done after approval of the research protocol by the animal ethics committee of the University of Limburg, Maastricht, The Netherlands.

After induction of anaesthesia using thiopentone 2 adult goats were ventilated with nitrous oxide, oxygen and halothane. The goats were then placed in the prone position. The $\mathrm{C}$-arm was positioned so that the $\mathrm{X}$-rays were parallel to the axis of the intervertebral foramen. With the $\mathrm{C}$-arm in this posi-

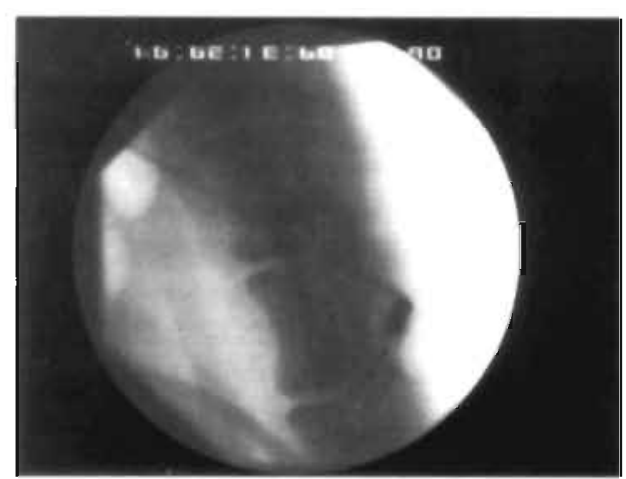

Figure 1. RF-DRG at level L3 (in goat) lateral view. electrode is positioned in the dorsal aspect of the. foramen. tion a $100 \mathrm{~mm}$ 22G SMK canula (Radionics) with a $5 \mathrm{~mm}$ exposed tip was introduced parallel to the direction of the X-rays. The tip of the canula was placed in the dorsal part of the intervertebral foramen (Fig. 1). 
The direction of the $\mathrm{X}$-rays was then changed to the antero-posterior position and the canula was further introduced until the tip was projected over the facetal column. The stylet was then replaced by a RF-probe. After checking the impedance, electrical stimulation was started at a rate of $2 \mathrm{~Hz}$ and the goat was observed for muscle contractions. The motor stimulation threshold was noted. At level L5 a $0.1 \mathrm{~V}$ stimulation threshold was achieved on purpose to position the electrode inside the ganglion.

RF-current was then led through the electrode in order to increase the temperature to $67^{\circ} \mathrm{C}$, in line with the procedure in the clinical situation. A 60 seconds $67^{\circ} \mathrm{C}$ lesion was made at each level, L1 to L5 on the left side (Group I). The same procedure was performed on the right side but no RF-current was applied (Group II). Finally, to obtain a reference value ganglia were studied from goats which were sacrificed for other experiments (Group III).

After two weeks general anaesthesia was repeated and the procedure was performed in the following manner: extra-peritoneal laparotomy was performed and the aorta abdominalis was ligated just under the diaphragm. The iliac, renal, superior and inferior mesenteric and coeliac arteries were ligated. The abdominal aorta was canulated and the spinal cord was washed with $2000 \mathrm{ml}$ of $2.5 \%$ glutar-aldehyde. A laminectomy was carefully performed from Th12 until L5. The spinal cord, dorsal root ganglia at the right and left side were dissected. After this the goat was sacrified following ethical standards.

From the control animals (Group III) the DRG's were dissected according to the same procedure and subjected to pathological examination.

\section{PATHOLOGY}

DRG's were postfixed overnight in buffered $4 \%$ formalin and routinely processed and paraffin embedded. Paraffin sections cut at $4 \mu$ were stained with Haematoxylin-eosin. For the Ki-67 (MIB-1) staining procedure $3 \mu$ thick paraffin sections were cut and routinely dewaxed in xylol and $100 \%$ ethanol. Endogenous peroxidase was blocked by immersion in $0.6 \% \mathrm{H}_{2} \mathrm{O}_{2}$ for $15 \mathrm{~min}$. After rinsing with demiwater antigen retrieval was performed by $10 \mathrm{~min}$. microwave pretreatment at $750 \mathrm{~W}$ in $10 \mathrm{mMl}$ citrate buffer $(\mathrm{pH}$ 6.0). After several washes in buffer, sections were incubated with a primary monoclonal antibody to MIB-1 (Immunotech, USA) and secondarily processed using a strept $A B C$ method. Negative controls were performed by omitting the primary antibody. Adult colon mucosa was used as a positive control. Counting was done at 400x magnification only. Neuronal profiles, containing at least one MIB-1 positive stained satellite cell nucleus were considered positive. The size of the lesions was measured using a micrometer eyepiece on the light microscopic level on HE-stained sections taking the largest diameter of reactive changes in or outside the DRG. 


\section{RESULTS}

Lesions which were made at a 0.1 V stimulation threshold (L5 goat A, L5 goat B) were located inside the DRG (Fig. 2). These lesions were small, grey areas 1.8 and 2.0 $\mathrm{mm}$ in diameter. Inside the lesions there were small haemorrhages near the nerve fibre sheaths. There was a total loss of myelinated fibres.

Lesions located posterior to the DRG were made at a higher stimulation threshold $(0.9-1.6 \mathrm{~V})$. These lesions were small, soft grey areas, $2.0-2.8 \mathrm{~mm}$ in size and they were located in the fatty tissue posterior to the DRG (Fig. 3). Although the ganglia themselves on HE-staining seemed to be unaffected by the lesion, high MIB-1 activity indicated significant proliferation on the lesioned side (Group I) (Fig. 4) compared with the control side (Group II) (mean left $4.66 \%$ right $1.37 \%, P<0.001$ ) (Figs. $5 A$ and $5 \mathrm{~B})$. There was also a slight negative correlation between the affected neuronal count and motor stimulation threshold' $(\mathrm{R}=-\mathbf{4 9 8})$. MIB-1 activity of the Group III DRG's was mean $0.3 \%$.

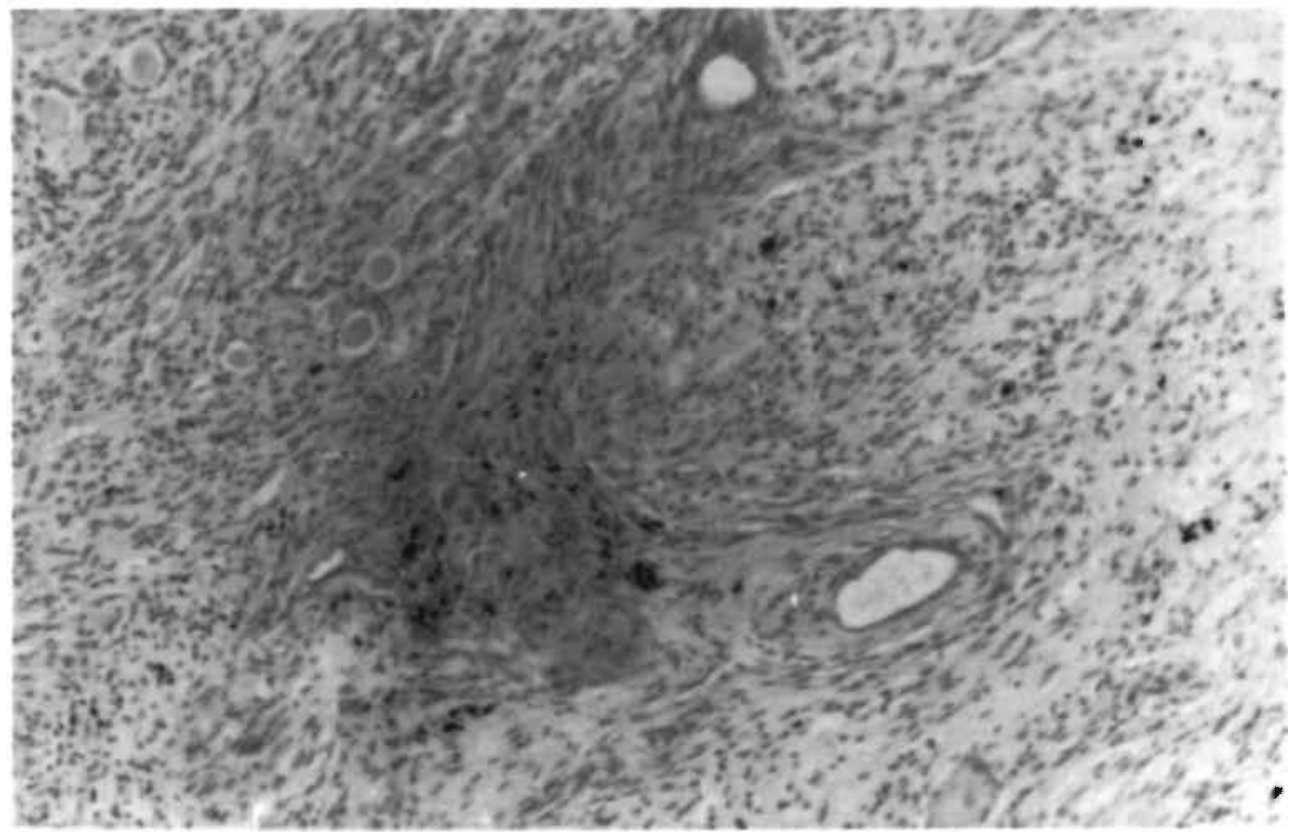

Figure 2. Lesion in the dorsal root ganglion. Iron deposition admits proliferating cells (Fe-stain)(50x). 


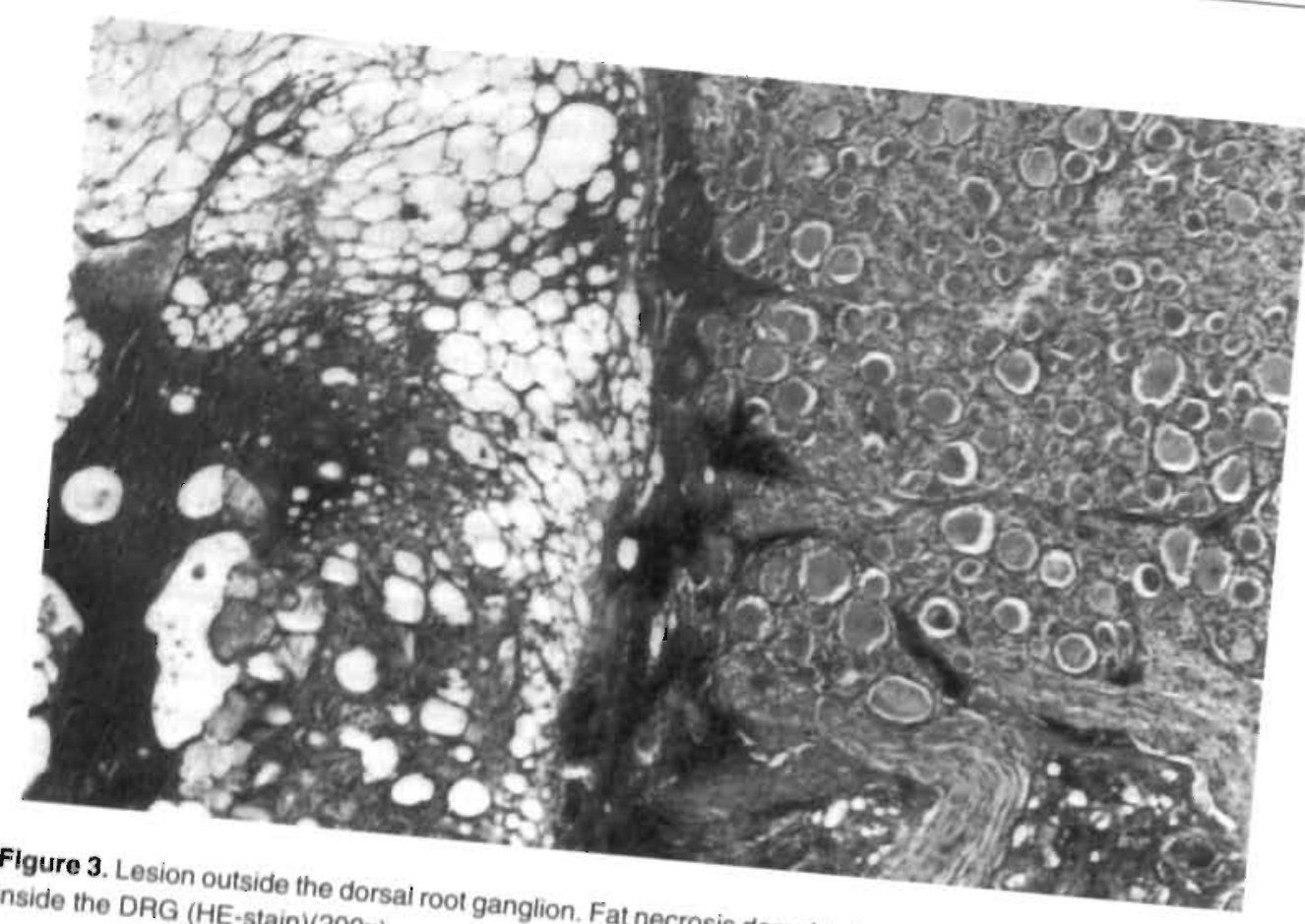

inside the $\mathrm{DPG}$ outside the dorsal root ganglion. Fat necrosis dorsal to the Do. Ne

D. Noremarkable changes

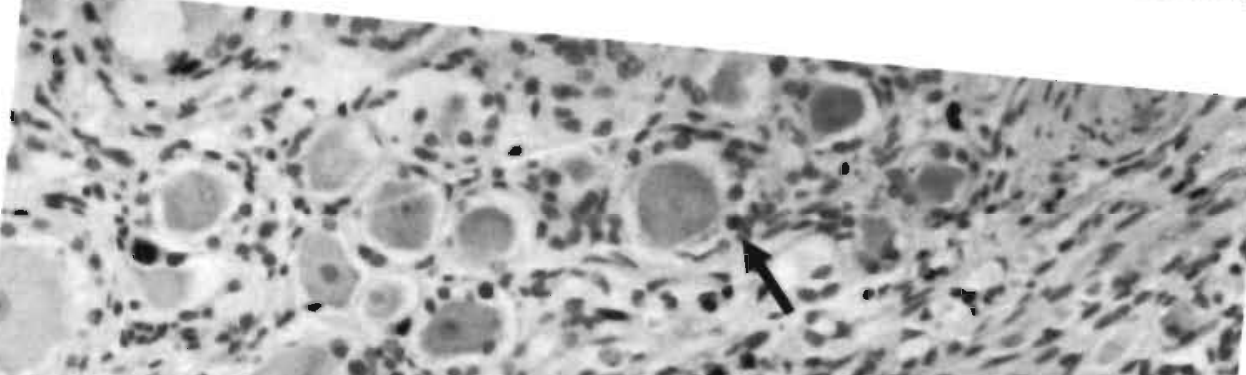

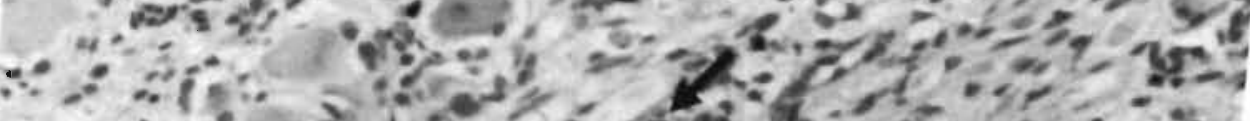

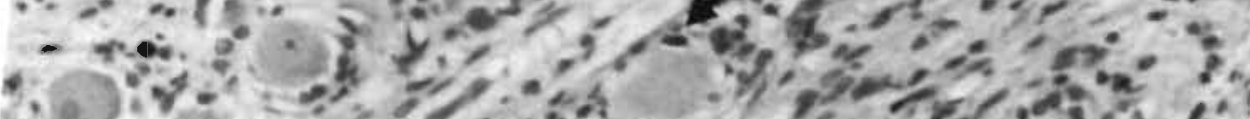

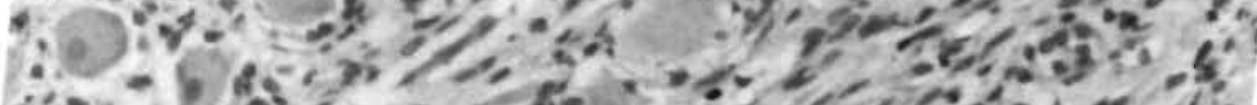
IF,

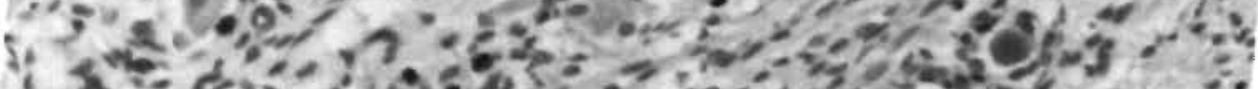

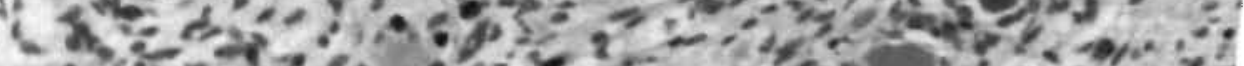

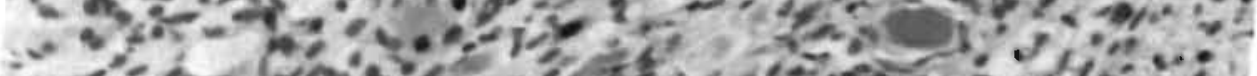

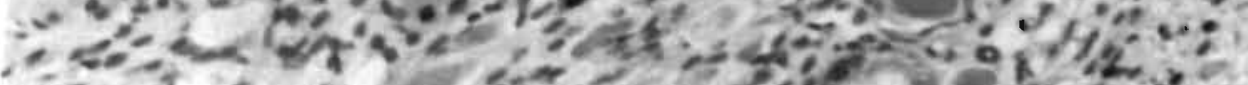

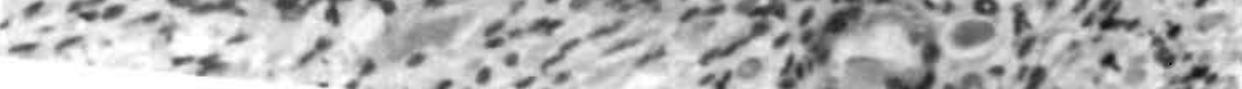

Figure 4. MIB-1 staining of DRG. Notice positive labellod 
10

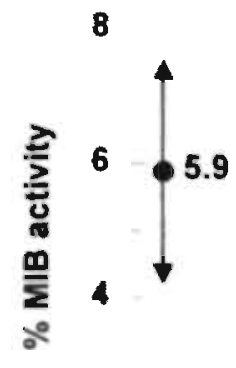

2<smiles>[Y19]</smiles><smiles>CCCOS(=O)(=O)O</smiles>
7.5

\section{3}<smiles>[131IH]</smiles>

0 L1

L2

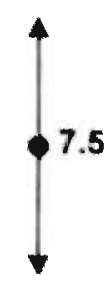

Figure 5a. Goat (A) percentage MIB-1 activity in dorsal root ganglion (satellite cells). Group I • = lesioned side; Group $\|$ ० = sham side

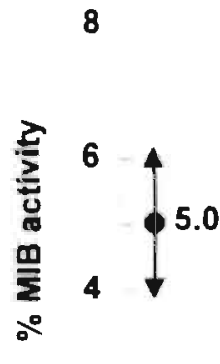

2
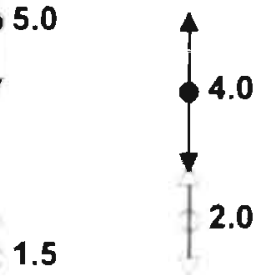

2.0
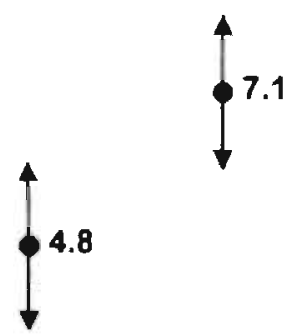

\section{Lovel}

L5 


\section{DISCUSSION}

Cosman et al. (1984) described four parameters determine the size of an RF-lesion, namely the central temperature of the lesion, the diameter of the electrode which has been used, the conductivity to heat of the surrounding tissues, and the vascularity in the vicinity of the electrode.

Computer models indicate that these factors may result in considerable variations in the size of the lesion (Sluijter and Van Kleef, 1995). In this study we find that RF-current under clinical conditions in the tissue posterior to the DRG (i.e. central temperature of $67^{\circ} \mathrm{C}$, for 60 seconds) results in a lesion size with a diameter of 2.0-2.8 $\mathrm{mm}$. This is well in accordance with studies in in vitro experiments (Bogduk et al. 1987, Moringlane et al. 1989, Vinas et al. 1992).

The effect of heat on nervous tissue is controversial. In a electrophysiological study Letcher and Goldring (1968) found that RF-current preferentially affects small unmyelinated nerve fibres. Smith et al. (1981) described that nerve destruction due to RF-current involves both myelinated and unmyelinated nerve fibres. However, this study was performed using a $14 \mathrm{G}$ electrode which was placed in the intervertebral foramen under direct vision. Similar results were reported by Uematsu (1977) using an identical technique.

All these studies describe the effects of RF-lesions which are made under circumstances not comparable to the technique which is now commonly used in clinical practice. Presently, positioning of the electrode is adjacent to, rather than in the DRG (Van Kleef et al. 1993, Van Kleef et al. 1996, Stolker et al. 1991). Therefore, the effect of an RF-lesion which is made with a $22 \mathrm{G}$ electrode and with a tip temperature of $67^{\circ}$ $\mathrm{C}$ was studied. Moreover, morphological effects of two different lesion localisations were studied, i.e. adjacent to, or inside the DRG.

The effect of an RF-lesion inside the DRG was in keeping with the morphological findings of Uematsu (1977) and Smith et al. (1981). There was indiscriminate destruction of both small and large nerve fibres inside the lesion. When the lesion was made adjacent to the DRG no darnage was seen under light microscopy. But there was a significant increase in MIB-1 activity. Immunohistochemically this indicates proliferation of satellite cells and regeneration of damaged nerve fibres.

The MIB-1 activity in the DRG's on the sham side (group II) was also higher than in the control DRG's (group III). This increase was small and was probably due to minor non-specific tissue damage by the needle alone.

The position of the electrode in relation with the DRG is therefore important, In our experiments electrostimulation turned out to be an indicator of this relationship. When the stimulation threshold was $<0.2 \mathrm{~V}$ the electrode was positioned inside the DRG. Higher thresholds coincided with electrode positions outside the ganglion. There was also a negative correlation between the stimulation threshold and the MIB-1 activity. 
In conclusion, an RF-lesion made well outside the ganglion does have an effect on the neurones inside the ganglion. This immunohistochemical finding is in accordance with the clinical observation that these lesions do have a clinical effect, without interfering with the function of large myelinated fibres.

\section{REFERENCES}

1. Bogduk N, Macintosh J, Marsland A. Technical limitations to the efficacy of radiofrequency neurotomy for spinal pain. Neurosurg 20:529-535, 1987.

2. Cathoretti G, Becker MHG, Key G, Duchrow M, Schluter C, Callet J and Gerdes J: Monocional antibodies against recombinant parts of the Ki-67 antigen (MIB 1 and MIB 3) defect proliferating cells in mircowave-processed formalin-fixed paraffin section. J Pathol 168:357-362, 1992.

3. Cosman ER, Nashold BS, Ovelman-Levitt J. Theoretical aspects of radiofrequent lesions in the dorsal root entry zone. Neurosurg 15:945-950, 1984.

4. Letcher FS, Goldring S. The effect of radiofrequency current and heat on peripheral nerve action potential in the cat. J Neurosurg 29:42-47, 1968.

5. Moringlane JR, Koch R, Schafer, Ostertag CB. Experimental radiofrequence (RF), coagulation with computer-based on line monitoring of temperature and power. Acta Neurochir 96:126-131, 1989.

6. Nash TP. Percutaneous Radiofrequency lesioning of dorsal root ganglion for intractable pain. Pain 24:67-73. 1986.

7. Sluijter ME, Van Kleef M. Factors governing the size of radiofrequency lesions - description of a computer model. Abstract 1st Scientific Meeting of the European Federation of IASP Chapters. Pain in Europe, Verona, May 18-21, 1995.

8. Smith HP. McWhorter JM, Challa VR. Radiofrequency neurolysis in a clinical model. J Neurosurg 55:246-253, 1981.

9. Stolker RJ, Vervest ACM. Groen GJ. Percutaneous facet denervation in chronic thoracic spinal pain. Acta Neurochir (Wien) 122:82-90, 1993 b.

10. Uematsu S. Percutaneous electrothermocoagulation of spinal nerve trunk, ganglion and rootlets. In: Schmidel HH. Sweet WS, eds. Current technique in operative neurosurgery. New York: Grune and Stratton, 1977. pp 469-490.

11. Van Kleef M, Liem L, Lousberg A, Barendse GAM, Kessels, AGH, Dingemans WAAM, De Lange S, Sluijter ME. Radiofrequency lesion adjacent to the dorsal root ganglion (RF-DRG) for cervicobrachial pain. A prospective double blind randomised study. Neurosurgery, in press

12. Van Kleef M, Spaans F, Dingemans, W. Barendse GAM, Floor A. Sluijter ME. Effects and side effects of a percutaneous thermal lesion of the dorsal root ganglion in patients, with cervical pain syndrome. Pain 52:49-53, 1993.

13. Vervest ACM, Stolker RJ. The treatment of cervical pain syndromes with radiofrequency procedures. Pain Clin 4:103-112, 1991.

14. Vinas FC, Zamorano L, Dujovny M, Zhao JZ, Hodgkinson D, Ho KL, Ausman JI. In vivo and in vitro study of the lesions produced with a computerized radiofrequency system. Stereotact Funct Neurosurg 58:121-133, 1992. 
CHAPTER 5 


\title{
CHAPTER 6
}

\section{Effects and side effects of a radiofrequency lesion of the dorsal root ganglion (RF-DRG) in patients with cervical pain syndrome}

\author{
M. van Kleef \\ F. Spaans \\ W.A.A.M. Dingemans \\ G.A.M. Barendse \\ E. Floor \\ M.E. Sluijter
}




\section{ABSTRACT}

Twenty consecutive patients with intractable chronic pain in the cervical region were treated with a radiofrequency lesion of the dorsal root ganglion (RF-DRG) on level C4, C5 or C6. Electromyography (EMG) and sensory evoked potentials (SEP) were recorded before and three weeks after the RF-lesion. Side effects were studied 3 weeks, 6 weeks and 3 months after the procedure. Pain scores were evaluated on Numeric Rating Scales (NAS) before and 6 weeks after treatment. The patient was interviewed 3,6 and 9 months after the RF-lesion.

The most common side effect was burning pain in the dermatome of the treated nerve root. Hyposensibility in the dermatome was noticed in $35 \%$ of patients. Except in one patient these side effects had disappeared 6 weeks after treatment. The EMG showed no signs of denervation. One SEP recording remained abnormal after treatment. There was initial pain relief in $75 \%$ of patients after 3 months and in $50 \%$ of the patients after 6 months. In conclusion: this study did not reveal any signs of motor denervation after an RF-DRG. There were no long term signs of deafferentation. Initial pain relief was found in $75 \%$ of patients but there was a marked tendency for pain to recur in a period from 3 to 9 months after treatment.

Keywords: cervical pain, radiofrequency lesions, dorsal root ganglion, sensory evoked potentials, electromyography. 


\section{INTRODUCTION}

Twenty percent of new patients visiting our pain clinic complain of pain in the cervical region. Some of these patients can be succesfully treated by conservative means such as immobilization and/or physiotherapy. If these methods fail, more aggressive forms of treatment may be considered.

A radiofrequency lesion of the dorsal root ganglion (RF-DRG) has been proposed as a form of treatment in patients with cervicall pain.

An RF-DRG was first described by Uematsu et al. (1974) and later by Lazorthes et al. (1976). Sluijter and Mehta (1981) modified this technique by introducing a small diameter, temperature monitoring electrode system. This modification was considered to contribute to the safety of the method. A literature search did not reveal any publications to substantiate this view. The aim of the study was to determine the safety and the efficacy of RF-DRG in patients with cervical pain.

\section{CLINICAL MATERIAL}

Twenty consecutive patients who presented with a history of at least one year of chronic pain in the cervical region which radiated to the head, shoulder and/or arm gave informed consent for the study. All patients had been extensively treated by conservative means without success. Patients with a tumour, inflammatory disease or clinically demonstrable neurological signs were excluded from the study. X-ray examination revealed signs of degenerative disease of the cervical spine in thirteen patients. Age, sex, the localisation and duration of the pain as well as the $\mathrm{X}$-ray findings are shown on table 1.

\section{METHODS}

After clinical evaluation by an independent investigator (EF) and registration of the data the patient was asked to score his/her pain level on a Numeric Rating Scale (NRS, rating 0-10) (Downie 1978).

After assessment diagnostic segmental nerve blocks under fluoroscopy were performed at all levels which were relevant, either to the localisation of the pain or to the findings on physical examination (Aprill et al. 1990, Caillet 1981, Dwyer et al. 1990, Ramamurthy 1986). These blocks included the levels C4, C5 and C6.

Following a small volume of omnipaque $(0.3 \mathrm{ml})$ for correct localisation, $1.0 \mathrm{ml}$ lignocaine of $1 \%$ solution was injected close to the nerve root $\mathrm{C} 4$.

Then at weekly intervals this procedure was repeated at levels C5 and C6. The level providing the best short analgesic response was selected for RF-treatment. Prior to making the RF-lesion, electrophysiological studies were performed. These studies were the cortical sensory evoked potentials. (SEP) and electromyography (EMG). 
Table 1.

\begin{tabular}{|c|c|c|c|c|c|c|c|c|c|c|c|c|}
\hline \multirow[t]{2}{*}{ Patierit } & \multirow[t]{2}{*}{ Localisation } & \multirow[t]{2}{*}{ Duration. } & \multirow[t]{2}{*}{ Ageisex: } & \multirow{2}{*}{$\begin{array}{l}\text { Panscore } \\
\text { (4) } 10\end{array}$} & \multirow[t]{2}{*}{ Xiay } & \multirow{2}{*}{$\begin{array}{l}\text { PFiopG } \\
\text { leve }\end{array}$} & \multicolumn{2}{|l|}{ Sode eflects } & \multirow{2}{*}{$\begin{array}{l}\text { Prinscare } \\
6 \text { weeds } \\
(0-10)\end{array}$} & \multicolumn{3}{|l|}{ Pessults } \\
\hline & & & & & & & 3 modes & 3 morths & & 3 monthis & 6 moriths: & 9 moniths \\
\hline 1 & neckltead & 3 years & $55 \mathrm{~m}$ & $\varepsilon$ & $\begin{array}{l}\text { spondylons cerveals } \\
\text { CA-CR }\end{array}$ & $\mathrm{CA}$ et & Trposen: & none & 2 & b & & \\
\hline 2 & necklam & $>20$ veart: & $5+1$ & 7 & $\begin{array}{l}\text { spondylons idicopattiy } \\
\text { CA-C6 }\end{array}$ & $\operatorname{Cs}$ en & sting burmo parn & none & 7 & & & $=$ \\
\hline 3 & neck/am & $>10$ reas & $6+\pi$ & 6 & sponaykats & CS eft & burning pain & none & 4 & c & $c$ & c \\
\hline 4 & fecknticialdeir & 13 reas & 534 & 10 & slignt discocalty CS-CB & CSight & strong berrmg pan & none & 10 & & - & \\
\hline 5 & reskiarm & 3 vears & $43 \mathrm{~m}$ & 6 & shont drscopattry C3-CA & $C .5$ eोf & byposens buming pan & none & 4 & c & - & \\
\hline 6 & neckiarm & 3 vears & $43 / \mathrm{m}$ & 7 & $\begin{array}{l}\text { spondyloses cerv } \\
\text { CAC5. CS-C6 }\end{array}$ & C.5 ett & bumneng pan & norve & 3 & b & a & a \\
\hline 7 & neckiftead/broudides & 1.3 yeurs & 45.7 & 9 & formal & CE ight & hyposens bumng paient & none & 9 & & - & \\
\hline a & neckilum & 7 years & $42 \mathrm{~m}$ & 8 & discopatty $\mathrm{CS} C \mathrm{CE}$ & $\mathrm{CA}=6$ & burneg paen hrposains & none & 1 & a. & a & \\
\hline i: & ineckhead/unoulder & $>10$ vears & 694 & 3 & $\begin{array}{l}\text { spononglósis idsocopatty } \\
\text { CE-CT }\end{array}$ & CAnore & burning pan hincosens & none & 3 & b & b. & b \\
\hline 10 & necaptesid & $>3$ years & 291 & 9 & normat & C5 vart & $\begin{array}{l}\text { SEP desayed heiryy } \\
\text { feeting righ amm }\end{array}$ & none & 2 & b & b & b \\
\hline 11 & 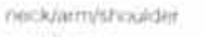 & 13 vears & $39 n$ & $?$ & normal & Co vitit & noner & none & 7 & - & & \\
\hline 12 & nexojen arm & 1,3 yars & 261 & 8 & nomait & C5 sghe & none & none & i & b & a & \\
\hline 13 & neckibom amsis & $>30$ yearn & $60 \mathrm{~A}$ & $\begin{array}{l}\text { could not } \\
\text { score NAS }\end{array}$ & disconally more leveis & CA eff & nore & none. & & & - & \\
\hline 14 & neckilunoulder & 1.3 yearn & 34,1 & 6 & normati & C5 sort & $\begin{array}{l}\text { hyposents } \\
\text { shoude-burnerig pian }\end{array}$ & $\begin{array}{l}\text { Irvosens } \\
\text { shoudder } \\
\text { disappeired } \\
\text { atter } 5 \text { months }\end{array}$ & 3 & $b$ & b & b \\
\hline 95 & neoshesad/antr & $>3$ mass & $44 \pi$ & 6) & sponidylasis C3-C6 & CAtont & buming pain & none. & 3 & b & ci & 0 \\
\hline 16 & nesplwad & $>30$ year & Exin & $\begin{array}{l}\text { could not } \\
\text { score NRS }\end{array}$ & noma! & $C A$ wht & rione & nonet & & b & $c$ & c \\
\hline 17 & nench/hend & $>26$ years & $533 \mathrm{~m}$ & 6 & oid fracture CS & CS off & butning pain hyposens: & none: & 5 & c & $c$ & e \\
\hline $1+$ & riectik/urn & 2.10 years & $54 \pi$ & $?$ & spondylartruxosis & Oe sight & burning pain & none & 3 & b & $\mathrm{b}$ & 0 \\
\hline 19 & neckhhouldoe & $>3$ yoars & 5221 & 8 & Etrong deg spondyionis & C6 ett & none & nane & 5 & Fi & c & 0 \\
\hline 20 & neckinhoulder & $>3$ years & $35 \mathrm{~m}$ & 7 & nomal & CS uth & heavy burnang pain & none & t & a & $a$ & a \\
\hline
\end{tabular}

$a=100 \%$ raliet $b=50-1005$ robiet, $c=30-50 \%$ retiet: $*<30 \%$ retiet, $0=$ no follow-up 
SEP recordings were made after stimulation of the relevant dermatome on both sides. For C4 the epaulet was chosen, for C5 the relevant part of the upper arm and for C6 the thumb.

Muscles of the relevant myotome were studied with concentric needle EMG technique. At least five muscles, including the paravertebral cervical musculature, were sampled for the occurrence of fibrillation potentials.

To perform the RF-DRG a conventional technique is used with the $\mathrm{C}$-arm positioned to have the X-rays parallel to the axis of the intervertebral foramen (Sluijter, 1990). This axis points $25-35^{\circ}$ anteriorly and $10^{\circ}$ caudally. With the $\mathrm{C}$-arm in this position, the entry point may be found by projecting a metal ruler over the caudal part of the foramen.

The canula (Radionics SMK C5 with a $2 \mathrm{~mm}$ exposed tip) is introduced in the direction of the X-rays and, if necessary, the direction is corrected while still in the superficial layers, until it is projected on the screen as a dot (see chapter 4, Fig. 3A).

In practice this dot should lie directly over the dorsal part of the intervertebral foramen at the transition between the middle and most caudal third part. This dorsal position is chosen in order to avoid possible damage to the motor-fibres of the segmental nerve and the vertebral artery which runs anterior to the ventral part of the foramen. The direction of the X-rays is then changed to antero-posterior and the canula is further introduced until the tip is projected over the middle of the facetal column (see chapter 4, Fig. 3B).

The stylet is now replaced by the RF-probe. After checking the impedance, electrical stimulation is started at a rate of $50 \mathrm{~Hz}$. The patient should feel a tingling sensation at a voltage $>0.2 \mathrm{~V}$ and $<1.2 \mathrm{~V}$. Next the frequency is changed to $2 \mathrm{~Hz}$ and the patient is observed for muscle contractions. These should not occur below a voltage of 1.5 $x$ the sensory threshold.

$0.5 \mathrm{ml}$ of omnipaque is now injected to exclude an accidental intradural position of the electrode (see chapter 4, Fig. 3C), and this is followed by $2 \mathrm{ml}$ of $2 \%$ lignocaine.

RF-current is then led through the electrode (Radionics RFG 3C lesion generator) in order to increase the temperature at the tip slowly to $67^{\circ} \mathrm{C}$. This temperature is maintained for 60 seconds. During our study this procedure was carried out with no untoward effects in any patient.

\section{FOLLOW-UP}

Follow-up was done by the same independent investigator, who performed the initial evaluation. After three weeks the patient was checked for the occurrence of any possible side effect of the therapy and also to repeat the electrophysiological investigations. After six weeks the occurrence of side effects was rechecked and the 
pain level was scored on the NRS. Three months after treatment the patient was asked to score pain relief then afforded as a percentage of the original pain level. The result was scored as painfree when there was complete pain relief; it was scored as good if there was $>50 \%$ pain relief, as moderate for $30-50 \%$ pain reliel and as of no effect for $<30 \%$ pain relief. Six months after treatment the same question was asked during an interview by telephone. In 17 patients there was a similar interview after nine months.

\section{RESULTS}

\section{Side effects.}

Two patients reported a troublesome burning pain whilst another 10 patients were aware of a vague burning sensation in the treated dermatome. In ail patients this type. of pain had subsided spontaneously six weeks after treatment (table 2).

In seven patients hyposensibility in the treated dermatome was noted after three weeks. It had disappeared after six weeks except in one patient (nir. 14). This was the only patient with an abnormal pre-treatment SEP (see below). She underwent a C5 RF-DRG. The sensory threshold was $0.2 \mathrm{~V}$. She had an unexplained hypaesthetic area on her shoulder 6 weeks after treatment outside the treated dermatome. Six months after treatment this hypaesthetic area had disappeared.

One patient (nr. 10), for two days, complained of a heavy feeling in the arm after a C5 RF-DRG.

\section{Electrophysiological investigations.}

In seventeen patients. EMG and SEP were recorded 1 week before and 3-4 weeks after Rif-lesioning. One patient (nr. 14) had a slightly increased C5 dermatomal SEP latency before treatment which remained unaltered after PPR. Another patient (nr. 10 see above) had a slighty increased SEP C5 dermatomal latency (4 milli seconds) after treatment, which was still noticeable after 9 months despite the absence of

Table 2.

\begin{tabular}{lll}
\hline & 3 weeks & 6 weeks \\
\hline Burning pain & $12(60 \%)$ & none \\
Hyposensibility in dermatome & $7(35 \%)$ & none \\
Motor complications & none & none \\
Reflex differences & none & none \\
\hline
\end{tabular}

Side effects after RF lesion 3 weeks and 6 weeks after treatment in twenty patients. 
Table 3.

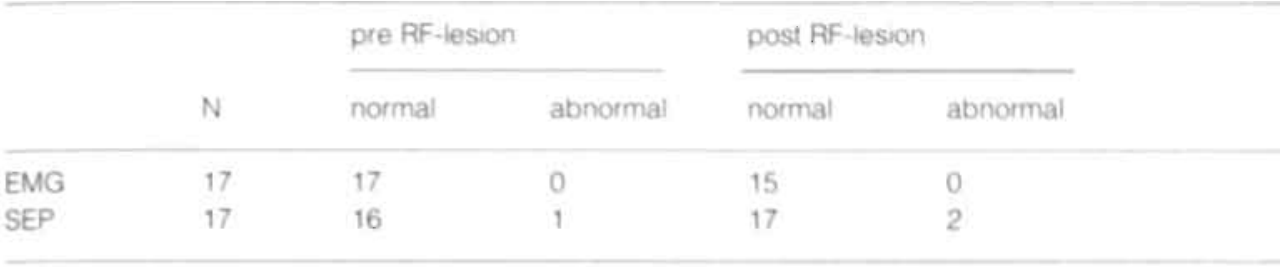

EMG and SEP recorded one week before RF lesioning and 3-4 weeks after RF lesioning.

Table 4 ,

\begin{tabular}{llllll}
\hline Folliow-up & N & Paintree & Good & Moderate & No effect \\
\hline 3 months & 20 & $2(10 \%)$ & $8(40 \%)$ & $5(25 \%)$ & $5(25 \%)$ \\
6 months & 20 & $4(20 \%)$ & $2(10 \%)$ & $4(20 \%)$ & $10(50 \%)$ \\
9 months & 17 & $2(11 \%)$ & $2(11 \%)$ & $3(17 \%)$ & $10(50 \%)$
\end{tabular}

Painscore after 3, 6 and 9 months.

Painfree ( $100 \%$ relief), good ( $50-100 \%$ relief), moderate ( $30-50 \%$ relief), no effect ( $<30 \%$ relief).

clinical findings. Both SEP latency and EMG were normal before as well as after treatment

in all other investigated patients (table 3). Three patients refused to undergo these tests after treatment.

\section{Pain relief.}

The mean score on the NRS before treatment was 7.2 (range 5-10). Six weeks after treatment the mean score was 4.2 (range 1-10). The pain relief score during follow up at 3-9 months is given in table 1 and table 4 .

\section{DISCUSSION}

It is the aim of an RF-DRG to interrupt noxious input through the small fibre system while leaving large fibre activity intact. In the ideal situation the sensory qualities of the relevant dermatome should be minimaly affected after this procedure, preventing the development of a deafferentation syndrome.

Since small fibres are presumably less resistant to heat (Letcher and Goldring 1968), an RF-lesion is suitable to obtain the desired effect. An RF-lesion has a central zone 
in which all fibres are destroyed. This central area is surrounded by a peripheral zone in which the temperature is relatively low.

If the central temperature of the lesion is low, the central zone can be expected to be small with respect to the peripheral zone.

Therefore, the use of an electrode system with the facility of temperature measurement is an essential part of the technique. The central temperature of $67^{\circ} \mathrm{C}$ was arbitrarily chosen, based on clinical experience with the procedure. Further research is required to determine the most appropriate temperature.

Our study supports the hypothesis that the large root fibres remain unchanged by the RF-thermal lesion. The hypaesthesia, which occurred in $35 \%$ of our patients, was transient (table 1). Motor disturbances did not occur and the EMG after the procedure did not show any signs of denervation. These findings are in accordance with a study by Nash (1986) who did not notice any motor deficit in 26 patients after an RF-DRG.

But these findings are in discordance with the neuropathological investigations done by Smith et al. (1981) and Kanpolat (1980) who showed that thermocoagulation destroyed, in an indiscriminate way, both small $C$ and $A-\delta$ fibres and also large $A-\beta$ fibres. However, these authors used 14 gauge electrodes whilst we used 22 gauge electrodes. This difference in size may partly explain the discrepancy in findings.

There was initial pain relief in $75 \%$ of our patients. $25 \%$ therefore did not respond to the $\mathrm{AF}$-block despite a positive diagnostic segmental nerve block. A number of factors may have been responsible for this:

- A technical failure of the procedure due to placement of the electrode in a highly vascular area in which the heat is quickly dispersed;

- A false positive diagnostic block due to inadvertent spread of the local anaesthetic solution into the epidural space:

- A type of pain which involved more than one segmental level.

Since our study was designed to investigate the effects of one single RF-lesion we have restricted treatment to the level which responded best to the diagnostic nerve block.

There was a recurrence of pain in a $33 \%$ of patients during the period between 3 and 9 months after treatment. This again may partly be due to involvement of another segmental level. It may also indicate that an RF-lesion should be regarded as a reversible procedure in many cases, rather than a procedure with a permanent effect.

This reversible procedure can nevertheless be useful since it provides for a relatively painfree period which can be utilised to obtain the maximum benefit from conservative forms of treatment such as physiotherapy (Sluijter 1988).

In conclusion, our study did not reveal any untoward effect of an RF-DRG. Initial pain relief after the procedure was good but there was a tendency for pain to recur after 
3 to 9 months. This may be due to limitations of our study, or it may signify that nerve root recovery occurs after an RF-lesion of this magnitude.

\section{REFERENCES}

1. Aprill C, Dwyer A. Fracs BS, Bogduk N. Cervical zygapophysial joint pain. Spine 15:458-461, 1990.

2. Caillet R. Functional anatomy in Neck and Arm Pain, Philadelphia, Davis Co. F.A. (1981)

3. Downie WW, Leatham PA, Rhind VW. Studies with pain rating scales. Anna Rheumat Dis $37: 378$ $381,1978$.

4. Dwyer A, Fracs BS, Aprill C. Bogduk N. Cervical zygapophysial joint pain. Spine, 15:453-457, 1990.

5. Kanpolat Y. Onol B. Experimental percutaneous approach to the trigemal ganglion in dogs with histopathological evaluation of radiofrequency lesions. Acta Neurochirurgica, 30:363-366, 1980.

6. Lazorthes $\mathrm{Y}$, Verdie JC, Lagarrigue J. Thermocoagulation percutanée des nẹts rachidiens à visêe analgésique. Neurochirurgie 22:445-453, 1976.

7. Letcher FS, Goldring S. The effect of radiofrequency current and heat on peripheral nerve action potential in the cat. J Neurosurg 29:42-47, 1968

8. Nash TP. Percutaneous radiofrequency lesioning of dorsal rọt ganglia for intractable pain. Pain 24:67-73, 1986

9. Ramamurthy S. Cervical Pain. In Ray PP. (ed.) Practical Management of Pain, Chicago Year Book Medical Publishers, pp. 418-430, 1986

10. Sluijter ME, Mehta M. Treatment of chronic neck and back pain by percutaneous thermal lesions. In: Lipton S, Miles J (ed.). Persistant pain, modern methods of treatment, Vol, 3. Academic Press, London. pp. 141-179, 1981.

11. Sluijter ME. Koetsveld-Baart CC. Interruption of pain pathways in the treatment of the cervical syndrome. Anaesthesia, 35:302-307, 1980.

12. Sluijter ME. Percutaneous thermal lesions in the treatment of cervical pain syndromes. Radionics Procedure Technique Series, Radionics Inc., Burlington Mass, (1990).

13. Sluijter ME. The use of radiofrequency !esions for pain in failed back patients. Int Disabil Stud 10:37-43, 1988.

14. Smith HP. Mewhorther JM. Challa VR. Radiofrequency neurolysis in a clinical model. J Neurosurg 55:246-253, 1981.

15. Uematsu, S, Udrarhely GB, Benson DW. Siebens AA. Percutaneous radiofrequency rhizotomy. Surg Neurol 2:319-325, 1974 


\title{
CHAPTER 7
}

The effects of producing a radiofrequency lesion adjacent to the dorsal root ganglion (RF-DRG) in patients with thoracic segmental pain

\author{
M. van Kleef \\ G.A.M. Barendse \\ W.A.A.M. Dingemans \\ C. Wingen \\ R. Lousberg \\ S. de Lange \\ M.E. Sluijter
}




\section{ABSTRACT}

Objective: To evaluate the effectiveness of a radiofrequency lesion adjacent to the dorsal root ganglion (RF-DRG) on a consecutive group of patients presenting with chronic thoracic pain.

Design: Retrospective study by a disinterested third party

Setting: Clinical outcome study.

Patients: 43 patients with a minimum of 6 months history of unilateral thoracic segmenta! pain, unresponsive to conservative therapy.

Intervention: Patients were selected for an RF-DRG after 2 or more prognostic nerve blocks had been performed under fluoroscopic control. The level which provided the best analgesic response was selected. At this level, an RF-lesion was made at $67^{\circ}$ for 60 seconds immediately adjacent to the dorsal root ganglion.

Outcome measurement: Rating of pain on a four step verbal rating scale.

Results: An RF-DRGi provided short term ( 8 weeks) reliet of pain in $67 \%$ and long term relief ( $>36$ weeks) of pain in $52 \%$ of patients with a limited segmental distribution of pain. If more than two segmental levels were involved, the procedure was found to be less effective.

Conclusions: There was a significantly $(P<0.05)$ better short term and long term pain relief in patients with a clearly localized pain that was confined to one or two thoracic segmental levels. compared to patients with more than two segmental levels involved in the pain syndrome.

Keywords: Thoracic pain, radiofrequency lesion, dorsal root ganglion, segmental levels. 


\section{INTRODUCTION}

Thoracic pain is the presenting symptom of $5-10 \%$ of new patients attending our pain clinic. In some patients an underlying pathology is found including old fractures, dislocation of intervertebral joints, postural disorders or neuropathy resulting from operations, herpetic infections or tumours. In many cases no such pathology is found and the pain is thought to be of spinal origin, emanating from nociceptive nerve endings in the periosteum, ligaments and joints (Bonica and Sola 1991).

When chronic nociceptive pain fails to respond to conservative measures such as physical therapy or medication, more aggressive forms of treatment may be considered. A radiofrequency lesion adjacent to the dorsal root ganglion (RF-DRG) has been proposed as a form of treatment in chronic nociceptive pain (Dubuisson 1994, Nash 1986, Stolker et al. 1994, Uematsu et al. 1974, Uematsu 1982, Van Kleef et al. 1993).

Percutaneous current lesions have been used in the treatment of chronic pain since Kirschner (1942) introduced the coagulation of the Gasserian ganglion in patients. with trigeminal neuralgia. Uematsu et al. (1974), introduced the RF-DRG. Sluijter and Mehta (1981) modified this technique by introducing the use of a small diameter (22G) temperature monitoring electrode system.

Results of this procedure in the management of pain have been reported in the cervical, thoracic and lumbar region (Dubuisson 1994, Nash 1986, Stolker et al. 1994. Van Kleef et al. 1993). However, these investigators did not evaluate the number of segments involved in the pain syndrome and the pain relief afforded by one single RF-DRG lesion.

The purpose of this study is to access the effectiveness of a single level RF-DRG, when patients with a limited (one or two) segmental nociceptal unilateral thoracic pain are compared to those with more than two involved segments.

\section{PATIENT MATERIAL}

All patients, entering the study had been extensively investigated (CT, MRI) by the referring specialist, who had excluded other pathological causes.

They presented with a history of a minimum of 6 months unilateral pain in the thoracic area with a segmental distribution. Previous treatment had been conservative. Medication, physical therapy and TENS (Transcutaneous Electric Nerve Stimulation), however, had not relieved their pain.

Patients with loss of sensibility in the painful area due to surgery (post-thoracotomy pain) or infection (post-herpetic neuralgia) were excluded from the study. A psychological test (SCL 90) was used to identify patients with psychological disorders (Derogatis et al. 1976); these patients were also excluded. 


\section{METHOD}

Patients meeting the inclusion criteria were assessed with 2 or more prognostic intercostal nerve blocks. After explaining the procedure to the patient, the patient was placed in a prone position. Using fluoroscopic control the rib of the segment to be blocked was identified. A point was found $2-3 \mathrm{~cm}$ lateral to the articulation of the rib with the transverse process. A 100 mm 22G Neurography needle (Radionics) was advanced at this point to the posterior surface of the rib. The needle point was then walked caudally until it slipped under

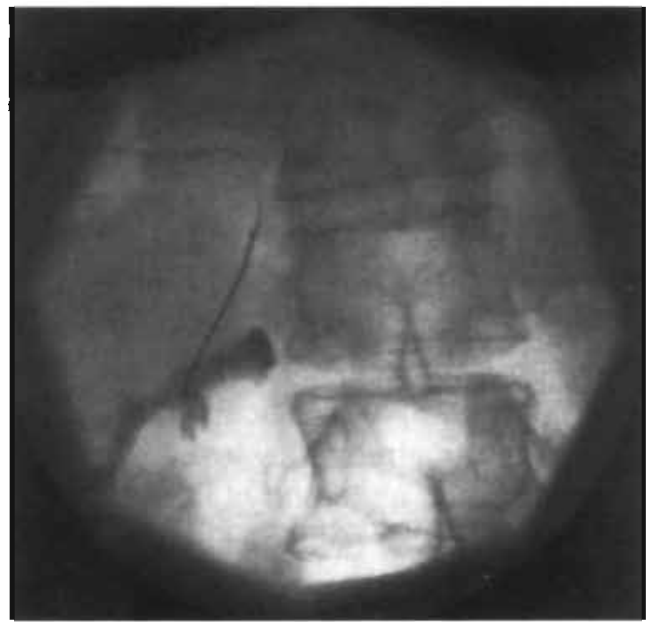

Figure 1. Fluoroscopic image of a prognostic intercostal block Th12.

the rib. After the intercostal nerve had been identified with $0.4 \mathrm{ml}$ lohexol contrast medium, $2 \mathrm{mi}$ of $2 \%$ lignocaine was slowly infiltrated around the nerve. The resultant radio-opaque mixture was closely observed during injection so that accidental overflow into the epidural space could be avoided (Fig. 1).

Pain relief was assessed 30 minutes after the procedure. Two or more adjacent levels were blocked with a 1 week interval between each segmental block. Patients with a positive response to the prognostic blocks (at least $50 \%$ temporary pain relief) were selected to undergo an RF-DRG. The level which provided the best analgesic response was selected for an RF-DRG.

For an RF-DRG below the level of $T 7$ the following technique was used. A $100 \mathrm{~mm}$ canula (Radionics SMK 22G, $5 \mathrm{~mm}$ active tip) was inserted $1 \mathrm{~cm}$ medial to the angle of the ribs. It was carefully advanced at an angie parallel to the ribs until it was placed in the cranio-dorsal part of the intervertebral foramen (see chapter 4, Figs. 4A and 4B). The stylet of the canula was replaced with an RF-probe and sensory stimulation was carried out at $50 \mathrm{~Hz}$. Correct positioning was determined when the patients perceived a tingling sensation in the selected dermatome using a $0.4-1 \mathrm{~V}$ stimulus. Electrical stimulation prior to making the lesion is important in identifying the correct needle position because an RF-DRG lesion made inside the ganglion could result in sensory deafferentation. Therefore the lesion must be made immediately adjacent to the ganglion. A tingling sensation at a stimulation of less than $0.4 \mathrm{~V}$ may indicate intra-ganglionic positioning, so that the needle point must be repositioned.

Stimulation was then performed at $2 \mathrm{~Hz}$. If the needle point was too close to the anterior root the patient perceived muscle contractions at a stimulation threshold below 1.5 times the sensory threshold. After satisfactory placement was achieved, 
contrast medium $(0.4 \mathrm{ml}$ lohexol) was injected to exclude intradural spread or vascular penetration. This was followed by $2 \mathrm{ml}$ of $2 \%$ lignocaine, which provided analgesia of the dorsal root ganglion. A 60 seconds $67^{\circ} \mathrm{C}$ lesion was made by using an RF-lesion generator system (Radionics RFG 3C) with a thermocouple electrode for continuous temperature measurement.

For an RF-DRG at T7 and above a different technique was used. Above T8 the angle of the ribs prevented accurate needle positioning. To overcome this problem, under fluoroscopic control, a small hole was drilled with an AO pneumatic drill through the lamina of the vertebrae using a 14G Kirschner wire to gain access to the intervertebral foramen. A 20G SMK 15 canula was then inserted (see chapter 4, Figs. 5A and 5B). Electrical stimulation and following steps were then carried out as described above. Two adjacent levels were never treated with RF-DRG becauce this might increase the chance of a deafferention syndrome.

Stimulation criteria, such as sensory threshold and motor stimulation were recorded by a trained assistant.

\section{Assessment}

The 1 st follow-up was done 8 weeks after the procedure. The result was scored in the same way as in our previous study (Van Kleef et al. 1993). Pain relief was scored as "pain free" if there was complete pain relief, as "good" if there was $>50 \%$ pain relief, as "moderate" for 30-50\% pain relief and as "no effect" for $<30 \%$ pain relief. A positive result was defined as "pain free", "good" or "moderate" pain relief. Complications and side effects were noted. The long term results (36 weeks or more) of the procedure were assessed by a disinterested 3th party (C.W.). If the RF-lesion therapy resulted in an equivocal pain relief or did not relieve the pain, subsequent RF-treatment was offered to the patients 3 months after the first. RF-DRG.

\section{RESULTS}

A total of 152 prognostic intercostal nerve blocks were performed in 55 patients. In 12 patients there was no temporary relief of pain after 1 or more prognostic blocks. The remaining 43 patients were entered into the study.

In 27 patients the presented distribution of pain was confined to 1 or 2 segmental levels (Group I). In 16 patients the presenting pain involved more than 2 segmental levels (Group II). Demographics, of both groups are summarized in table 1.

In 14 cases there were abnormalities on the thoracic X-ray. In 6 cases these abnormalities were related to the level of the pain syndrome. Diagnosis of the following clinical pain syndromes were made: post-traumatic neuralgia, segmental peripheral neuralgia (Merskey and Bogduk 1994), slipping rib syndrome (Copeland et al. 1984), twelfth rib syndrome (Machin and Shennan 1983) and collapse of vertebrae, due to osteoporosis. Spinal deformaties such as scoliosis, kyphosis and degenerative changes were called 'pain of spinal origin'. The clinical diagnosis related 
Table 1. Demographics of patients.

\begin{tabular}{lll}
\hline & Group I & Group II \\
\hline Number & 27 & 16 \\
Age (mean) & 56.3 (30-82 years) & 48.6 (16-65 years) \\
Sex & & \\
male & 11 & 11 \\
female & 16 & 5 \\
& & \\
Durations of complaints (months) & 15 & 7 \\
$6-36$ months & 4 & 2 \\
$36-60$ months & 8 & 7 \\
$>60$ months & &
\end{tabular}

Demographics of patients with a pain localised to one or two segmental levels (Group I) and those with a pattern involving more than two segmental thoracic levels (Group II).

to the segmental levels involved in the pain syndrome of the patients included in this study, are summarized in table 2.

\section{Pain relief}

After 8 weeks follow-up visit, $18(67 \%)$ out of 27 patients in Group I had pain relief. Of these 18 patients, $6(22 \%)$ had "complete" relief of pain, $8(30 \%)$ had "good" relief of pain and $4(15 \%)$ reported "moderate" relief of pain (table 3 ).

8 patients underwent a procedure at a second segment. 6 of these had had initial pain relief for 8-18 weeks. Thereafter, the original pain intensity returned. A further 2 patients had "no relief" of pain, and their pain was believed to come from a second segment. This second procedure gave "good" to "excellent" sustained pain relief in 2 of these 8 patients. Overall, $52 \%$ of patients in Group I had long term pain relief (>36 weeks). The degree of pain relief is listed in table 3 . This pain relief was maintained until the time of the last follow-up. The average duration of follow-up was 98.7 weeks (range $36-168$ weeks).

At the 8 week follow-up visit in Group II, there was initial pain relief in 6 of 16 patients $(36 \%)$. Of these, 2 patients (12\%) reported "complete" pain relief, 1 had "good" pain relief $(6 \%)$ and 3 recorded "moderate" relief of pain $(18 \%)$.

In 4 patients a second procedure was performed, which gave "good" relief in 1 and "moderate" relief in another.

Long term pain relief (>36 weeks) in this group was observed in $30 \%$ of patients (table 3 ). The long term follow-up in this group was at a mean of 128 weeks (range 40-160 weeks).

Comparing Group I to Group II patients, there is a significant difference in both short term $\left(\mathrm{chi}^{2}=2.80 ; \mathrm{df}=1 ; \mathrm{p}<0.05\right)$ and long term $\left(\mathrm{chi}^{2}=3.46 ; \mathrm{df}=1, \mathrm{p}<0.05\right)$ relief of pain. 
Table 2. Clinical diagnosis.

\begin{tabular}{lccc}
\hline & Group I & Group II & All \\
\hline Posttraumatic segmental neuraigia & 0 & 1 & 1 \\
Collapse of a vertebrae & 2 & 1 & 3 \\
Slipping rib syndrome & 1 & 2 & 3 \\
Tweith rib syndrome & 9 & 0 & 9 \\
Pain of spinal onigin & 4 & 3 & 7 \\
Segmental peripheral neuralgia & 11 & 9 & 20 \\
\hline & 27 & 16 & 43
\end{tabular}

Clinical diagnosis related to segmental distribution of pain, localised to one or two segments (Group I), more than two segments involved (Group II).

"(Spinal deformaties such as scoliosis, kyphosis and degenerative changes of the spine).

Table 3. Results.

No of cases painfree good moderate noffect

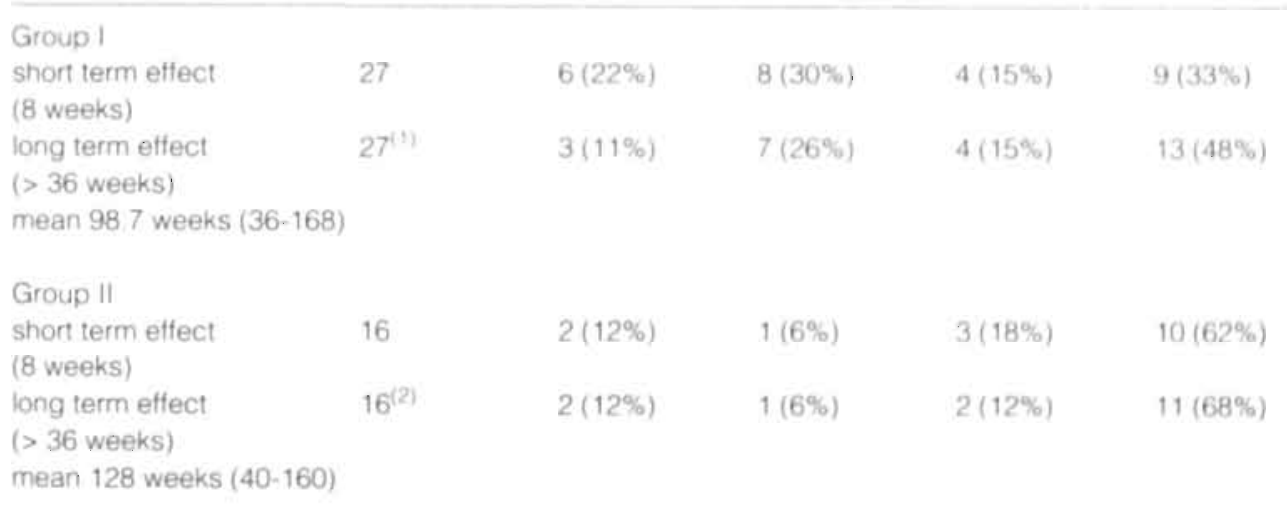

Short term ( 8 weeks) and long term (> 36 weeks) result in patients undergoing AF-DRG.

(1) eight reinterventions are considered

(2) four reinterventions are considered

Table 4 shows the relation between sensory threshold, during electrical stimulation prior to lesion making and result. on pain relief after 8 weeks. These data were available in 39 patients and showed no relation between sensory threshold and therapy-effect $\left(\mathrm{chi}^{2}=7.60, \mathrm{df}=6, \mathrm{P}=0.27\right)$. 
Table 4. Relation between sensory threshold and effect on pain.

\begin{tabular}{|c|c|c|c|c|c|}
\hline Threshold $V$ & $N$ & Pain free & Good & Moderate & No effect \\
\hline $0.40 \cdot 0.50$ & 17 & $3(18 \%)$ & $3(18 \%)$ & $5(29 \%)$ & $6(35 \%)$ \\
\hline $0.50-0.80$ & 14 & $1(7 \%)$ & $3(21 \%)$ & $1(7 \%)$ & $8(57 \%)$ \\
\hline \multirow[t]{2}{*}{$>0.80$} & 8 & $3(37 \%)$ & $1(13 \%)$ & $0(0 \%)$ & $4(50 \%)$ \\
\hline & 39 & & & & \\
\hline
\end{tabular}

Relation befween sensory threshold, during electrical stimulation prior to lesion making and effect on pain after eight weeks (chi ${ }^{2}=7.60$, df $=6, P=0.27$ two tailed).

\section{Side effects}

14 patients experienced a mild burning pain in the treated dermatome for some days following treatment. No medication was needed and patients found this sensation acceptable. 7 patients had slight hypo-aesthesia in the treated dermatome as noted on sensory testing at the first follow-up. These side effects had disappeared without therapy in all patients after 12 weeks. No major complications, such as dysaesthesia, were seen and no patient claimed that their pain had increased after treatment.

\section{DISCUSSION}

\section{Mechanism}

The purpose of performing an RF-DRG is to interrupt noxious input through the small-afferent fibre system, and to leave the large fibre system intact. Cosman (1984) depicted the lesion as extending beyond the tip for a distance of about 1.5 electrode diameters. Moringlane et a! (1989) and Bogduk et al. (1987) described the relationship between lesion size, temperature and size of the electrode in vivo and in vitro. An RF-lesion has a central zone with a high temperature. This central zone is surrounded by a peripheral area in which the temperature is relatively low. The central temperature of $67^{\circ} \mathrm{C}$ was arbitrarily chosen and was based on clinical experience with the procedure. The effects of RF-induced heat on nerve fibres is still not clearly understood. Letcher and Goldring (1968) found that RF-lesions selectively block small myelinated and unmyelinated fibres. These findings were later contradicted by morphological studies (Smith et al. 1981) which indicated that RF-current indiscriminately destroys both small and large fibres. Further studies elucidating this discrepancy have not been done but clinically it has been found that electromyography (EMG) and sensory evoked potentials (SEP) remain unchanged after an RF-DRG in the cervical region (Van Kleef et al. 1993). These findings may indicate that the majority of large fibres remain intact after the procedure. 
Symptomatic pain therapy is only indicated when patients have been extensively screened, exclude pathology which would require therapy such as disc herniations, aneurysms, or malignant causes of the pain syndrome. All of the patients in our study had been screened extensively to exclude these causes before referral.

In our opinion RF-DRG treatment should be restricted to a nociceptive pain syndrome. In most of our patients $(46.5 \%)$ a diagnosis was made of intercostal neuralgia without underlying pathology. In 12 patients the pain was due to underlying "rib pathology". In 3 patients the neuralgia was due to osteoporosis, which had resulted in a collapsed vertebrae.

Pain syndromes with sensory loss due to nerve damage, such as post-thoracotomy pain, post-herpetic neuralgia and post-mastectomy syndrome, are in our opinion not indications for RF-DRG. These syndromes may well be caused by deafferentation. We believe that there is a potential hazard that treatment with RF-DRG might intensify symptoms by augmenting the deafferentation component.

Prognostic blocks were used to select the patients for RF-DRG. The value of these prognostic blocks prior to RF-procedures is controversial for various reasons:

1. These blocks may give a false positive response because the injected local anaesthetic solution may easily spread to adjacent segmental levels. If spinal nerve blocks on thoracic level are used the local anesthetic solution may easily overflow into the epidural space and a false positive result may occur. For this reason we use the more peripheral intercostal approach to confirm the diagnosis of segmental pain and also to determine the level of treatment;

2. There is a complete cessation of afferent inflow during the time of action of the local anaesthetic. This is different from the partial reduction of afferent input which is caused by RF-DRG;

3. A prognostic nerve block does not solve the problem of referred pain. Normal input from a referred area may contribute to pain (Kibler and Nathan 1960). Therefore a positive diagnostic nerve block does not prove that there is a nociceptive focus distal to the block.

Pain which is clearly of other etiologies in the same segment may also be relieved after a prognostic block (Xavier et al. 1988);

4. The patient may be so affected by the 'hospital environment' that he may not clearly interpret the effect of the prognostic block.

Despite the above, we believe that prognostic blocking is the best available method to determine the nociceptive level.

\section{Technique and complications}

The posterolateral approach has a number of disadvantages, In the upper thoracic area the foramina face more anteriorly and the angle of the ribs may prevent accurate positioning of the needle. The potential hazards of the posterolateral approach above. the level of T8 are: 
- Penetrating the pleura with a resulting pneumothorax;

- Puncture of the arteries running anteriorly to the foramen;

- A lesion made too peripheral in the nerve may cause a de-afferentation syndrome;

- A position too medial using this approach may penetrate the dura and may cause spinal cord damage (Koning et al. 1991, Sluijter et al. 1991).

When the intervertebral foramen is approached with a small hole drilled in the lamina of the vertebrae, a more accurate positioning of the electrode is facilitated. This avoids the problems of the posterolateral approach.

It can be accurately performed using fluoroscopy and is well tolerated by the patient. A potential danger is piercing the facet joint (Stolker et al. 1994). In our series this has not occurred.

\section{RESULTS}

This study demonstrated that $67 \%$ of patients reported "moderate" to "complete" short term relief of pain after an RF-DRG. $52 \%$ of patients reported "moderate" or better long term pain relief, provided that the pain distribution was restricted to 1 or 2 segments (Group I). In 15\% of patients there was a "moderate" pain relief. We have included "moderate" pain relief as a positive result because it does have clinical relevance in the future management of the patients pain. A 30-50\% reduction of the intensity of the pain, makes the pain more acceptable for the patient and thus more amenable to conservative forms of therapy, which may not have helped previously. For most patients an acceptable situation was created with additional therapy (rehabilitation, low dose amitryptiline, TENS).

Of particular interest it was noted that $75 \%$ of patients with the twelfth rib syndrome had a "good" to "pain free" result. Patients with this syndrome often present with chronic pain in the loin with radiation to the groin. On physical examination, manipulation of the distal part of the twelfth rib exactly reproduces patients' pain. Segmenta! peripheral neuralgia had a "good" to "pain free" result in $>50 \%$ of cases, when the pain was limited to one segmental level.

This pain syndrome is characterised by pain in the distribution of an intercostal nerve and is sometimes associated with cutaneous tenderness in the affected dermatome.

This study also indicates, that our selection criteria and/or our technique failed in $33 \%$ of patients in Group I and in $62 \%$ in Group II. This might be due to some factors. The first is related to patient selection. In our opinion there is a high false positive response to prognostic blocks due to the factors we have mentioned above. When there is any doubt about the effect of a prognostic block it is always advisable to test adjacent levels on a different occasion. Alternatively, the block may be repeated with a local anaesthetic with a different duration of action. This could differentiate between the 'actual' effect (time duration) of the block from the 'placebo' effect.

Secondly, RF-DRG has its limits. Stolker et al. (1994) pointed out that using the dorsal-lateral approach no neural tissue was within reach of the electrode tip in $25 \%$ 
of cases. In vivo, this situation should be detected by electrical stimulation. This study showed that placement of the electrode very close to the DRG (sensory threshold $0.4-0.5 \mathrm{~V}$ ), was not significantly related with a better result, compared to lesions made with a higher sensory threshold $(>0.8 \mathrm{~V})$.

Our long term results indicate that there is a tendency for pain to recur after an RF-DRG. This might be due to the intersegmental nervous connections in the innervation of the thoracic spine or to the involvement of another segment. It also indicates that an RF-lesion should be regarded in many as a reversible procedure. In patients with a wider distribution of pain the short and long term results are very limited. This may indicate that an RF-DRG is a procedure that blocks nociceptive stimuli in one specific segment.

In conclusion, an RF-DRG provided pain relief in the long term in $52 \%$ of patients with a limited segmental distribution of thoracic pain. If more than 2 segmental levels are involved the procedure was found to be less effective. Although the success rate of the procedure may be regarded as limited, we judge these results as acceptable, because this patient group consisted of chronic pain patients in whom other forms of therapy had failed.

\section{REFERENCES}

1. Bogduk N, Macintosh J, Marskind A. Technical limitations of the efficacy of radiofrequency neurotomy of spinal pain. Neurosurg 4:529-35, 1987.

2. Bonica JJ, Sola AF. Chest pain caused by other disorders. In: Bonica JJ, ed. The management of pain. Philadelphia: Lea and Febiger, 1114-1145, 1991.

3. Copeland GP, Machin DG. Shennan JM. Surgical treatment of the slipping rib syndrome. Br J Surg 522-3. 1984

4. Cosman ER, Blaine PhD, Nashold S, Oveiman-Levitt J. Theoretical aspects of radiofrequency lesions in the dorsal root entry zone. Neurosurg 6:945-50. 1984.

5. Derogatis LR, Rickels K, Rock AF. The SCL90 and the MMPI: a step in the validation of a new self report scale Br J Psychiat 128:280-9, 1976.

6. Dubuisson D. Root surgery. In: Wall PD, Melzack R, eds. Textbook of Pain: Churchill Livingstone. 1055-65, 1994.

7. Kibler RW, Nathan PW. Relief of pain and paresthesiae by nerve block distal to the lesion. J Neurol Neurosurg Psychiat 23:91-8, 1960.

8. Kirshner M. Die Behandlung der Trigeminusneuralgie. Munch Med Wschr 89:235-9, 1942

9. Koning HM, Koster HG, Niemeyer RPE. Ischaemic spinal cord lesion following percutaneous radiofrequency spinal thizotomy. Pain 45:161-6, 1991

10. Letcher FS, Goldring $\mathrm{S}$. The effect of radiofrequency current and heat on peripheral nerve action potential in the cat. J Neurosurg 29:42-7, 1968.

11. Machin DG, Shennan JM. Twelfth rib syndrome: a differential diagnosis of loin pain. Br Med J $287: 586$. 1983.

12. Merskey H. Bogduk N. Classification of chronic pain IASP Press Seattle, 137-48, 1994.

13. Moringlane JR, Kock R. Schäfer H. Ostertag ChB. Experimental radiofrequency coagulation with computer-based on tline monitoring of temperature and power. Acta Neurochir 96:126-31, 1989.

14. Nash TP. Percutaneous radiofrequency lesioning of dorsal root ganglia for intractable pain. Pain 24:67-73. 1986 . 
15. Sluijter ME, Dingemans. WAAM, Barendse GAM, Van Kleef M. Comment on 'ischaemic spinal cord lesion following percutaneous radiofrequency spinal rhizotomy' by Koning HM, Koster HG, Niemeyer RPE in Pain 45:161-6, 1991. Pain 47:241, 1991.

16. Sluijter ME, Mehta M. Treatment of chronic neck and back pain by percutaneous thermal lesions. In: Lipton S, Miles J, eds. Persistant pain. Methods of treatment, vol. 3. London: Academic Press, 141-79, 1981.

17. Smith HP, Mc Worther JM, Challa VR. Radiofrequency neurolysis in a clinical model. J Neurosurg 55:246-53, 1981.

18. Stolker RJ, Vervest ACM, Groen GJ. The treatment of chronic thoracic segmental pain by radiofrequency percutaneous partial rinizotomy. J Neurosurg 80:986-92, 1994.

19. Stolker FJ, Vervest ACM, Ramos LMP, Groen GJ. Electrode positioning in thoracic percutaneous partial rhizotomy: an anatomical study. Pain 57:241-51, 1994.

20. Uematsu S. Percutaneous electrothermocoagulation of spinal nerve trunk, ganglion and rootlets. In: Schmidel $\mathrm{H}$, Sweet $\mathrm{WH}$, eds. Operative neurosurgical techniques: indications methods and results. New York: Grune and Stratton, 1171-98, 1982.

21. Uematsu S. Udrarhely GB, Benson DW. Siebens AA. Percutaneous radiofrequency rhizotomy. Surg Neurol 2:319-25, 1974.

22. Van Kleef M, Spaans F, Dingemans W, Barendse GAM, Floor E, Sluijter ME. Effects and side effects of a percutaneous thermal lesion of the dorsal root ganglia in patients with cervical pain syndrome. Pain 52:49-53, 1993.

23. Xavier AV, McDanal J, Kissin I. Reliel of sciatic radicular pain by sciatic nerve block. Anesth Analg $67: 1177-80,1988$. 


\title{
CHAPTER 8
}

Radiofrequency lesion adjacent to the dorsal root ganglion (RF-DRG) for cervicobrachial pain: a prospective double blind randomized study

\author{
M. van Kleef \\ L. Liem \\ R. Lousberg \\ G.A.M. Barendse \\ A.G.H. Kessels \\ M.E. Sluijter
}




\section{ABSTRACT}

Twenty consecutive patients with a history of at least one year intractable chronic cervical pain radiating to head, shoulder and/or arm, were, after selection with at least three diagnostic segmental nerve blocks, randomly assigned to one or two treatment groups. Group I received a $67^{\circ} \mathrm{C}$ radiofrequency lesion of the dorsal root ganglion (RF-DRG) Group II was treated in an identical manner but no electric current was used. Neither the therapist nor the patient were aware of the treatment group assignment.

Both one week prior as well as eight weeks after the procedure the patients were questioned about their pain using the following tests: Visual Analogue Scale (VAS). McGill Pain Questionnaire Dutch Language Version (McGill PQ-DLV). Multidimensional Pain Inventory Dutch Language Version (MPI-DLV). These tests showed that eight weeks after the procedure there was a significant number of 'success' patients in group I compared to group $\|(P=0.0027)$; there was a significant reduction in VAS score $(p<0.01)$, and also in parameters measured with MPQ-DLV and MPI-DLV in group I. This study indicates that a $67^{\circ} \mathrm{C}$ RF-DRG can result in a significant allevation of pain in chronic cervical pain.

Keywords: cervical pain, radiofrequency lesion, dorsal root ganglion. 


\section{INTRODUCTION}

Cervical pain is a frequent presenting symptom in patients visiting a pain clinic. The cause of this type of pain is unknown, any of the structures of the neck that receive nerve supply can be a source of cervical pain. These structures include neck muscles, facet joints and/or intervertebral discs (Bogduk and Aprill 1993). When cervical pain radiates to the head, shoulder or arm involvement of the segmental nerve may contribute to the pain syndrome. Segmental pain may be caused by compression of the exiting nerve root due to either a prolapsed disc or to degenerative changes. Sluijter (1990) suggested that a complex irritation phenomenon due to changes in cervical mobility may be the cause of this cervical pain syndrome. In most cases symptoms subside by conservative measures such as rest, manipulation or physiotherapy. If these fail active treatment may be considered.

It has been proposed that these patients with persistent cervical pain radiating to shoulder and arm may be treated with a radiofrequency lesion adjacent to the dorsal root ganglion (RF-DRG) (Sluijter and Koetsveld-Baart 1980, Sluijter and Mehta 1981. Sluijter et al. 1990). The extent of these lesions can be controlled by means of a temperature monitoring electrode system (Bogduk et al. 1987) and causes little patient discomfort (Van Kleef et al. 1993). Although some patient studies report that this form of treatment is effective in $75 \%$ of patients (Van Kleef et al. 1993) to $80 \%$ of patients (Vervest 1991) in short term, no randomised controlled studies on this subject have been published.

A prospective double-blind controlled study was initiated in order to investigate the short term effects of a $67^{\circ} \mathrm{C}$ RF-DRG lesion in the cervical area.

\section{PATIENTS AND METHODS}

After approval of the hospital ethical committee, patients were included in the study provided that the following criteria were met:

- Written informed consent;

- A minimum of one year history of continuous pain in the cervical region radiating to the shoulder and/or arm;

- Failed conservative treatment such as physiotherapy and/or manipulation;

- Initial VAS-pain score of at least 4.0 (on a 10-points scale);

- Aged between 20 and 60 years;

- Temporary pain relief after a diagnostic segmental nerve block.

Patients with a whiplash trauma, systemic disease, a tumour, extensive degenerative changes on x-ray or clinically demonstrable neurological deficit and/or signs of radicular compression, were excluded from the study.

At weekly intervals diagnostic segmental nerve blocks were performed at all levels which were relevant to the localisation of pain. These blocks included the levels C4, 
C5 and C6. The level which provided at least 50\% pain relief to the patient was selected for treatment. After written informed consent was obtained, the patient was enrolled in the study. Patients were randomly assigned to one of two groups.

Group I: These patients were treated with an RF-DRG at $67^{\circ} \mathrm{C}$.

Group II: These patients were treated with the identical technique but no RF-lesion was made (a sham lesion with no current flow).

Both the patient and the therapist were blinded, the patient was not aware of the type of treatment they received and the doctor, who was involved in the study, left the operating room after positioning the electrode and injecting the local anaesthetic. The RF-lesion generator (Radionics RFC-3C) was operated by an independent investigator.

Stimulation criteria, such as sensory threshold, motor stimulation or any pain perceived by the patient during the lesion were recorded by the investigator.

\section{Technique of a diagnostic segmental nerve block and assessment}

To perform a diagnostic segmental nerve block a viewing technique is used with the $\mathrm{C}$-arm so positioned that the $\mathrm{X}$-rays are parallel to the axis of the intervertebral foramen. This axis points $25-35^{\circ}$ anterior and $10^{\circ}$ caudal. With the $\mathrm{C}$-arm in this position the entry is found by projecting a metal ruler over the caudal part of the foramen.

A $50 \mathrm{~mm}$ 22G Neurography needle (Radionics) is carefully introduced parallel to the beam of the $\mathrm{X}$-rays. Than the direction of the $\mathrm{X}$-rays is changed to anterior-posterior position and the canula is further introcluced until the tip is projected just lateral from the facetal column. After the segmental nerve had been identified with $0.4 \mathrm{ml}$ lohexol contrast medium, $0.5 \mathrm{ml}$ of $2 \%$ lignocaine is slowly infiltrated around the nerve. The resultant radio-opaque mixture was closely observed during injection so that accidental overflow into the epidural space could be avoided (see chapter 4, Fig. 3C).

Pain relief was assessed 30 minutes after the procedure. Three of more adjacent levels were blocked with a 1 week interval between each block. Patients with a positive respons to the prognostic block (at least $50 \%$ temporary pain relief) were selected to undergo an RF-DRG. The level which provided the best analgesic response was selected for treatment.

\section{Technique of RF-DRG}

The same viewing technique is used as in the diagnostic block. The entry-point is found by projecting the metal ruler over the caudal and posterior part of the foramen. The canula (Radionics SMK C5 with a 2-mm exposed tip) is introduced parallel to the beam of the $X$-rays and, if necessary, the approach is corrected whilst still in the superficial layers until the canula is projected on the screen as a single dot (see chapter 4, Fig. 3A).

In practice this dot should lie directly over the dorsal part of the intervertebral foramen at the transition between the middle and most caudal third part. This dorsal position 
is chosen in order to avoid possible damage to the motor fibres of the segmental nerve and to the vertebral artery which runs anterior to the ventral part of the foramen. The direction of the X-rays is then changed to antero-posterior and the canula is further introduced until the tip is projected over the middle of the facetal column (see chapter 4, Fig. 3B).

The stylet is now replaced by the RF-probe. After checking the impedance, electrical stimulation is started at a rate of $50 \mathrm{~Hz}$. The patient should feel a tingling sensation between 0.4 and $0.65 \mathrm{~V}$. The frequency is then changed to $2 \mathrm{~Hz}$ and the patient is observed for muscle contractions. These should not occur below a voltage of $1.5 \mathrm{x}$ the sensory threshold.

One-half millilitre of omnipaque is now injected to exclude an accidental intradural positioning of the electrode and this is followed by $2 \mathrm{ml}$ of $2 \%$ lignocaine.

RF-current is then passed through the electrode (Radionics RFG $3 \mathrm{C}$ lesion generator) in order to increase the temperature at the tip slowly to $67^{\circ} \mathrm{C}$. This temperature is maintained for 60 seconds.

\section{Evaluation criteria}

Data were collected one week before and 8 weeks after treatment. The following information was obtained from the patients:

1. The pain intensity at that time was scored on a Visual Analogue Scale (VAS) (Jensen et al. 1986);

2. The McGill Pain Questionnaire, Dutch Language Version, MPQ-DLV (Van der Kloot and Vertommen 1989). Apart from the effect on the total Pain Rating Index (PRI) the effect on the categories of the PRI, consisting of the sensory component (PRS), affective component (PRA) and evaluative component (PRE) were considered;

3. The Multidimensional Pain Inventory, Dutch Language Version, MPI-DLV (Lousberg 1994). The effect on the Pain Severity (PS) scale (range 0-6), containing pain estimates of both the present moment and the previous week, was investigated.

A reduction of two points or more on the VAS was considered a clinically important reduction of pain. In our experience, patients who had a two points or more reduction on VAS score found that their pain had become acceptable. These patients were called 'success' patients. If the patient claimed no pain relief after 8 weeks the code was broken so that patients with a sham lesion, who continued to have pain symptoms, could have an RF-procedure if they so desired.

\section{Side effects}

Eight weeks after the procedure there was an evaluation of side effects. A neurological examination was performed to assess any sensory disturbance and/or reflex difference after the procedure. 


\section{Statistical analyses}

Because of some low cel frequencies, $(<5)$, differences in success rates in the two treatment groups were analysed using the Fisher exact test. For the differences in success rate, that is the value after 8 weeks follow-up minus the base line value, the two sample t-test was used.

\section{RESULTS}

\section{Patient material}

Diagnostic segmental test: blocks were performed on twenty-five consecutive patients with diffuse segmental cervical pain radiating to the shoulder or/and arm. Three patients had no temporary pain relief after three separate diagnostic blocks and were excluded from the trial. Two patients refused randomisation and were treated with a $67^{\circ} \mathrm{C}$ RF-DRG lesion. This left eight men and twelve women who participated in the study. Nine patients were treated with the RF-DRG technique (group I) and eleven patients were assigned to the sham group (group II). The mean age was 43.32 years (S.D. $=6.83$ ). The mean duration of pain complaints was 7.68 years $(S . D .=7.56)$.

One patient (assigned to group I) was not able to fill out the MPQ-DLV and MPI-DLV. From this patient only the VAS score was available. The analysis of the MPQ-DLV and MPI-DLV test was performed on the data of 19 patients.

Before testing the effect of treatment, an analysis was carried out to exclude possible initial group differences. There were no differences between the two groups with regard to the variables gender, age, duration of pain and pre treatment VAS pain intensity (table 1).

All tests mentioned below were carried out on a 1-tailed basis. Applying the above mentioned success criterion of two points decrease on the VAS pain intensity scale the results as shown in table 2 were obtained.

In the sham group there were 2 'success' patients and 9 'no-success' patients. In the $67^{\circ} \mathrm{C}$ lesion group there were 8 'success patients' one 'no-success' patient. The number of 'success' patients was higher in the RF-DRG lesion therapy group compared to the sham group and this difference was statistically significant $(p=0.0027$ Fisher exact test).

Mean VAS data before and after treatment are depicted in table 3. The difference in pain reduction (3.2 VAS points) between the two groups, was significant $(t=2.78$, d. $f=18, p<0.01)$.

The results of the statistical tests on the other measures are shown in table 4. On all variables except the affective pain-component of the McGill significant changes were observed. 
Table 1. Baseline data of patients treated (group I: $67^{\circ}$ C RF-DRG, group It:'sham')

\begin{tabular}{lll}
\hline & Group I & Group II \\
\hline No. of patients & 9 & 11 \\
Sex & \\
female & 5 & 7 \\
male & 4 & 4 \\
Age (years) & $47.4 \pm 12$ & $44.3 \pm 8$ \\
Duration of pain & & \\
$<1$ year & 0 & 0 \\
$1-5$ years & 5 & 6 \\
$>5$ years & 4 & 59 \\
\hline
\end{tabular}

VAS (mean)

6.4

5.9

Table 2. Number of 'success' patients (group I versus group II, $p=0.0027$ ).

Success No Success

Group 1

8

1

(67" C RF-DRG)

Group II

2

9

('sham')

Table 3. Mean VAS-score one week before and 8 weeks after treatment.

\begin{tabular}{lcc} 
& Pre-VAS & VAS (8 weeks) \\
\hline Group I & 6.4 & 3.3 \\
$\left(67^{\circ} \mathrm{C}\right.$ RF-DRG) & \\
Group II & 5.9 & 60 \\
(Sham RF-DRG) & &
\end{tabular}


Table 4. Treatment results of the dependent variables, differences between one week before and 8 weeks after treatment.

\begin{tabular}{|c|c|c|c|c|c|c|}
\hline & \multicolumn{2}{|l|}{$R F-D R G$} & \multicolumn{2}{|l|}{ Sham } & \multicolumn{2}{|l|}{ Values } \\
\hline & Mean diff. & S.D & Mean diff. & S.D. & t-value & $\mathrm{p}$-value \\
\hline VAS & -3.10 & 2.73 & 0.10 & 2.52 & 2.78 & 0.01 \\
\hline PS & -1.67 & 1.77 & -0.10 & 1.39 & 2.16 & 0.023 \\
\hline PRI & -11.22 & 12.67 & -0.40 & 11.23 & 1.97 & 0.032 \\
\hline PRS & -4.67 & 7.26 & 1.00 & 7.33 & 1.69 & 0.050 \\
\hline PRA & -2.78 & 3.23 & -0.90 & 3.81 & 1.15 & 0.133 \\
\hline PRE & -3.78 & 3.11 & -0.50 & 2.12 & 2.71 & 0.004 \\
\hline
\end{tabular}

VAS: Visual Analoge Scale; PS: (Subjective) Pain Severity (MPI); PRI: Total Pain Rating Index (MPQ): PRS: Pain Rating Index Sensory Component: PRA: Pain Rating Index Affective Component; PRE: Pain Rating Index Evaluative Component.

Table 5. Side effects after treatment.

\begin{tabular}{lll} 
& Group I $(n=9)$ & Group $\|(n=11)$ \\
\hline Pain & $7(77 \%)$ & $3(27 \%)$ \\
(mean duration) & $(17$ days $)$ & $(7$ days $)$ \\
Motor complications & none & none \\
Reflex differences & none & none \\
Hypaesthesia & 1 & 1 \\
\hline
\end{tabular}

RF-DRG lesion and side effects

A evaluation of side effects was made. One patient (group I) noticed a mild burning pain whilst actually performing the lesion. In group I ( $67^{\circ}$-grous) seven patients ( $77 \%$ ) noticed a vague burning sensation in the treated dermatome; this subsidedi spontaneously three weeks after treatment.

In group II (sham group) three patients $(27 \%)$ were aware of some dull non-radiating pain around the needle introduction site after the procedure which disappeared without therapy after one week. On physical examination there were no reflex-differences. One patient of group. I noticed a slight hypaesthesia on the lateral side of the upper arm. One patient of group II noticed a slight hypaesthesia of the left thumb (table 5). These side effects had disappeared after three months. 


\section{DISCUSSION}

The mechanism of action of RF-lesions in the treatment of pain is still the subject of debate in the literature. Letcher and Goldring (1968) in a neurophysiological study found a selective effect of heat on small myelinated and unmyelinated nerve fibres. Smith et al. (1981) described uniform destruction of both small and large fibres in a morphological study. In a previous study in patients with a cervical pain syndrome treated with an RF-DRG (Van Kleef et al. 1993) it was found that after the lesion the electromyogram (EMG) and the sensory evoked potential (SEP) remained unchanged. These findings indicate that the majority of the large fibres remain intact after a $67^{\circ} \mathrm{C}$ RF-DRG lesion. It is not clear whether the relief of pain is caused by the RF-lesion alone or whether other factors contribute such as the administration of local anaesthetic or a placebo-effect due to the needle puncture and placing. This randomised study was performed in order to clarify this question. We found it essential that in the sham group no RF-current was used since even small changes in temperature may cause damage to nervous tissue and may therefore have some effect on pain (Smith et al. 1981). Furthermore it is not known what effect an electrical field may have in this situation. However, where an actual lesion is compared to a no current sham lesion, from this study it appears that the effect on pain relief is due to the rise in temperature produced by the RF-current.

RF-lesions may be considered in the treatment of chronic cervicobrachialgia if there is a segmental distribution of nociceptive pain which does not respond to conservative therapy.

Since there appears to be no relationship between radiological abnormalities and the pain perceived (Friedenberg and Miller 1963, Heller et al. 1983, Jensen et al. 1994), the relevant area which contributes to pain can only be demonstrated by performing diagnostic segmental nerve blocks.

Although diagnostic nerve blocks are the best available diagnostic tool the results of these blocks should be regarded with caution. This is not only because there are technical hazards such as overflow of local anaesthetic to neighbouring structures but also because diagnostic nerve blocks do not mimic the effect of an RF-lesion; a diagnostic nerve block inhibits all afferent input from the relevant area for a short period of time, whereas RF-lesion may only block part of the input for a prolonged period of time.

When the long-term effects of the RF-DRG lesion are reviewed only uncontrolled studies are available in the literature (Van Kleef et al. 1993, Vervest and Stolker 1991). Good initial results are described in $75 \%$ of patients followed by a recurrence of pain in $44 \%$ of patients (Van Kleef et al. 1993). This underlines the importance of using the period of initial improvement for treatment with other methods in order to reinforce the effect on pain relief. A definite evaluation on the value of RF-lesions in the treatment of spinal pain will only be possible when the results of prospective longterm outcome studies become available. 
In summary, an RF-DRG lesion of $67^{\circ} \mathrm{C}$ gave a significant reduction of the pain intensity at least for 8 weeks after treatment; the mechanism of action is still unclear but might be due to reduction of segmental nociceptive input.

\section{REFERENCES}

1. Bogduk N, Aprill C. On the nature of neck pain, discography and cervical zygapophysial joint blocks. Pain 54:213-217, 1993.

2. Bogduk N, Macintosh J, Marsland A. Technical limitations to the efficacy of radiofrequency neurotomy tor spinal pain. Neurosurgery 20:529-535, 1987.

3. Friedenberg ZB, Miller WT. Degenerative disc disease of the cervical spine $J$ Bone Joint Surg 1171-1178, 1963.

4. Heller CA, Stanley P. Lewis-Jones B. Heller RF. Value of X-ray examinations of the cervical spine. Br Med J 1276-1279, 1983.

5. Jensen MC, Brant-Zawadzki MN, Obuchowski N, Modic MT, Malkasian D. Ross JS. Magnetic resonance imaging of the lumbar spine in people without back pain. N Engl J Med 331:69-73, 1994.

6. Jensen MP, Karoly P. Brauer S. The measurement of clinical pain intensity: a comparison of six methods. Pain 27:117-126, 1986.

7. Letcher FS, Goldring S. The effect of radiofrequency current and heat on peripheral nerve action potential in the cat. J Neurosurg 22:42-47, 1986.

8. Lousberg R. Chronic, pain. multiarial diagnostic and behavioral mechanisms. Thesis. UPM Universitaire Pers, Maastricht, 1994.

9. Moringlane JA, Koch $\mathrm{R}$, Schäfer $\mathrm{H}$. Ostertag $\mathrm{ChB}$. Experimental radiofrequency coagulation with computer based on the monitoring of temperature and power. Acta Neurochir 96:126-131, 1987.

10. Sluijter ME. Percutaneous thermal lesions in the treatment of cervical pain syndromes, Radionics Procedure Technique Series, Radionics Inc. Burlington MA (1990).

11. Sluliter ME, Koetsveld-Baart CC. Interruption of pain pathways in the treatment of cervical syndrome. Anaesthesia 35:302-307, 1980.

12. Sluijter ME. Mehta M. Treatment of chronic neck and back pain by percutaneous thermal lesions, in: Lipton S and Miles J (eds.): Persistant Pain, Modern Methods of Treatment, vol. 3, Academic Press. London, 1981. pp 141-179.

13. Sluitter ME, Rohof OJJM, Vervest AMC. Cervical pain - diagnosis with the aid of computerised analysis of cervical mobility. Pain 5:410, 1990.

14. Smith HP, Mewhorther JM, Challa VR. Radiofrequency neurolysis in a clinical model. J Neurosurg 55:246-253, 1981.

15. Van Kleef M, Spaans F. Dingemans W, Barendse G. Floor E, Sluijter ME. Effects and side effects of a percutaneous thermal lession of the dorsal root ganglion in patients with cervical pain syndrome. Pain 52:49-53, 1993.

16. Van der Kloot WA, Vertommen H. MPQ-DLV een standaard Nederlandse versie van de McGill Pain Questionnaire. Lisse (The Netherlands). Swets and Zeitlinger.

17. Vervest ACM, Stolker RJ. The treatment of cervical pain syndromes with radiofrequency procedures. The Pain Clinic 4:103-112. 1991. 


\section{CHAPTER 9}

\section{Summary and conclusion}

In chapter 1: The impact of spinal pain on society is discussed.

This thesis concerns radiofrequency (RF) techniques in the treatment of spinal pain. It focusses on the efficacy and on the potential side effects of a radiofrequency lesion of the dorsal root ganglion (RF-DRG).

A lesion at this location is of interest for two reasons:

1. Efficacy. All pain fibres conducting nociceptive information have their cell bodies in the dorsal ganglion. Small lesions made adjacent to the ganglion may therefore result in an effective reduction of nociceptive input.

2. Selectivity. RF-lesions reportedly have a selective effect on small unmyelinated C-fibres, leaving myelinated fibres relatively intact. This might open the possibility of reducing pain while maintaining sensory qualities.

The aim of the thesis is to evaluate the efficacy and safety of an RF-DRG in the treatment of spinal pain. In order to solve this problem the following questions were formulated:

a. What are the morphological changes in the dorsal root ganglion as a result of an RF-DRG?

b. Are there signs of motor denervation after an RF-DRG?

c. What is the clinical effect of an RF-DRG on pain perception?

d. Is the treatment of chronic spinal pain by an RF-DRG better than placebo treatment?

In chapter 2: The history of RF-lesioning and the theoretical aspects of these lesions are discussed.

A literature review concerning the size of the lesion using different types of equipment and different tip temperatures is given. The controversial aspects of the effect of an RF-lesion on nerve tissue is discussed.

All morphological studies indicate that RF-current applied directly to nerve tissue destroys all unmyelinated and myelinated fibres. No studies are available concerning RF-DRG.

In chapter 3: General considerations for treatment of spinal pain with RF-techniques are discussed.

Several classifications of pain and spinal pain are given. The innervation of the spine is discussed and also the diagnosis in spinal pain and the role of RF-lesions in treatment. The value of diagnostic blocking and the pitfalls of these blocks are discussed. 
In chapter 4: Review of the clinical syndromes in the cervical, thoracic and lumbar area, which are relevant for the treatment of chronic spinal pain with RF-techniques. Also the RF-techniques are discussed.

In chapter 5: Morphological changes in the dorsal root ganglion were evaluated in goats. Using fluoroscopic control, RF-DRG's were made at 5 lumbar levels, 22 G 100 $\mathrm{mm}$ SMK electrodes with a $5 \mathrm{~mm}$ active tip were positioned posterior to the lumbar dorsal root ganglion of L1-L5. Sixty seconds $67^{\circ} \mathrm{C}$ RF-lesions were made unilaterally. On the contralateral side electrodes were similarly placed but no RF-lesion was made. The goats were sacrificed two weeks after the procedure. The lesions were studied for size as well as for effects on proliferation and regeneration using Ki-67 (MIB-1). The single lesion made in the L5 lumbar ganglion in the two separated models were $1.8 \mathrm{~mm}-2.0 \mathrm{~mm}$, respectively. These lesions located within the dorsal root ganglion, showed a total loss of myelinated fibres, as shown by light microscopy in $\mathrm{HE}$-stained sections.

These changes were not observed when the lesion was made adjacent to the dorsal root ganglion. However, in these ganglia, using immunohistochemical technique (MIB-1) microscopic changes were observed. There was a significantly higher MIB-1 activity in the ganglia which had had a. lesion of the dorsal root ganglion when compared to ganglia where a sham lesion was made.

In chapter 6: Possible denervation sequelae of RF-DFG were assessed in patients with chronic cervicobrachialgia. The patients were selected for treatment after at least three diagnostic blocks at the relevant levels $(\mathrm{C} 4, \mathrm{C} 5, \mathrm{C} 6)$. The level providing the best temporary analgesic response, was selected for RF-DRG. Electromyography (EMG) and sensory evoked potentials (SEP) were recorded before and three weeks after RF-lesioning, in order to investigate the incidence of unwanted damage to. myelinated fibres.

Also side effects and the effect on pain were studied. After the procedure the EMG showed no signs of denervation. One SEP recording remained abnormal after treatment. There was relief of pain in $75 \%$ of patients 3 months after treatment and in $50 \%$ of patients 6 months after treatment.

In chapter 7: Clinical evaluation of RF-DRG as a therapy for chronic pain was done. on a consecutive group of patients presenting with chronic thoracic, pain.

Patients were selectedi for an RF.DRG after two or more diagnostic bloc.ks had been performed under fluoroscopic control. The level providing the best analgesic response was selected for treatment. At this level an RF-DRG was made. An RF-DRGi provided short-term (8. weeks) relief of pain in $67 \%$ and long term pain relief ( $>36$ weeks) in $52 \%$ of patients with a limited distribution of pain.

In chapter 8: Placebo-controlled treatment effects were evaluated in a prospective double blind randomised study performed in patients with unilateral chronic cervicobrachialgia. 
Twenty consecutive patients with a history of, at least, one year of intractable chronic cervicobrachialgia, were randomly assigned to one of two treatment groups. Group I received a $67^{\circ} \mathrm{C}$ RF-DRG. Group I| was treated in an identical manner but no RF-lesion was made. Both one week prior to, as well as eight weeks after the procedure the patients were questioned about their pain using different tests. These tests showed that eight weeks after the procedure there was a significant number of patients with pain reduction in group I compared to Group II.

\section{CONCLUSION}

a. The morphological changes in the dorsal root ganglion following RF-DRG.

An RF-lesion made inside the dorsal root ganglion resulted in an indiscriminate destruction of nervous tissue, when viewed by light microscopy in HE-stained sections, two weeks after the lesion was made.

These changes were not observed in a dorsal root ganglion when the lesion was made adjacent to the dorsal root ganglion and viewed using the same technique and timespan. However, using an immunohistochemical technique in the same ganglia after two weeks, an increased MIB-1 activity was observed in the satellite cells indicating proliferation and regeneration of nervous tissue. This indicates that the extend of the effect of an RF-lesion is larger than is visible by using light microscopy.

\section{b. The signs of motor denervation after RF-DRG.}

The electromyography (EMG) study performed in 17 patients did not show any signs of motor denervation after an RF-DRG. One sensory evoked potential (SEP) recording was changed after treatment, indicating damage to small myelinated fibres. The most common side effect was a temporary mild burning pain in the treated dermatome. A transient hyposensibility in the dermatome was noticed in $35 \%$ of patients. Except for one patient all side effects had disappeared 6 weeks after treatment. In conclusion, this study did not reveal any signs of motor denervation after RF-DRG. There were no long term signs of deafferentation.

\section{c. Clinical effects of one single RF-DRG on pain.}

The clinical efficacy of one single RF-DRG was evaluated in patients with chronic. thoracic pain and in the group of patients with chronic cervicobrachial pain:

1. In the patients with cervicobrachial pain there was an initial relief of pain in $75 \%$ of patients. 3 months after treatment. However, 3-9 months after treatment the original pain gradually returned in $35 \%$ of patients;

2. On the thoracic level one single RF-DRG provided short term ( $<8$ weeks) pain relief in $67 \%$ of patients and long term pain relief (>36 weeks) in $52 \%$ of patients 
with a limited segmental distribution of pain. If more than two levels were involved in the pain syndrome, the procedure was found to be less effective.

\section{d. The efficacy of one single RF-DRG on chronic cervicobrachialgia compared to placebo.}

The results of the prospective double blind study showed that 8 weeks after the procedure there was a significant number of patients with pain reduction after an RF-DRG compared with the placebo group of patients.

This study indicates that an RF-DRG can result in a significant alleviation of chronic cervicobrachial pain.

\section{Closing remarks}

On theoretical grounds an RF-DRG is a potentially elegant procedure to induce pain relief in chronic spinal pain syndromes.

We undertook several studies as to the clinical applicability of this procedure. One of these studies clearly shows that the procedure does not produce any serious complications such as denervation of motor fibres. The experimental animal study demonstrated that the technique enables one to produce an effect on the ganglion, without actual positioning the electrode inside the ganglion.

Clinical efficacy studies showed pain relief in $67-75 \%$ of selected patients with chronic: spinal pain after one RF-DRG. On a long term basis (36 weeks) this positive effect was still present in $40-52 \%$ of patients.

It appeared that the pain relief obtained by RF-DRG tends to decrease over time. The cause of this phenomenon remains obscure. It may be due either to the multisegmental innervation of the spine or due to regeneration of nerve fibres.

If multisegmental innervation plays a role in the phenomenon, one could consider producing multiple RF.lesions for better long term effects. Outcome studies should be periormed to evaluate this. Should regeneration of nervous tissue play a role in the gradual decrease of clinical benefit, then treatment could consist of a repeated procedure. This would be permissible since morphological and neurophysiological studies indicate that an RF-DRG can be performed without any effect on motor fibres and only temporary effect on small myelinated afferent fibres.

Another possible method to reduce the gradual decrease of clinical response, is the combination of RF-lesions and rehabilitation programs. The period of pain relief could then be utilized to obtain maximum benefit from conservative treatment such as rehabilitation and improvement of function. The effect of a combination of several modalities of treatment should be the subject of future studies. 


\section{CHAPTER 10}

\section{Samenvatting en conclusie}

Chronische pijn is een belangrijk probleem in de alledaagse medische praktijk.

Afgezien van de psychosociale consequenties voor de individuele patiënt, heeft chronische pijn ook financiële gevolgen voor de samenleving. Het merendeel van de mensen met chronische pijn heeft pijn die uitgaat van de wervelkolom. De oorzaak voor het ontstaan van deze pijn is vaak onduidelijk.

In ongeveer $15 \%$ van de patiēnten met lage rugklachten worden er zgn. "specifieke" oorzaken van lage rugpijn aangetoond zoals, "hernia" van de tussenwervelschijf. infecties, verschuiving van wervels of oude wervelfracturen. Deze patiēnten kunnen meestal door een causale behandeling (bv. operatie) van zijn of haar klachten verlost worden.

In de meerderheid van de gevallen blijft de oorzaak van de klachten, ondanks geavanceerde methoden van onderzoek, onduidelijk.

Diverse onderzoekers hebben pijn, waarvoor geen zekere oorzaak te vinden is, getracht te classificeren.

Eén van de onderzoekers verdeelt pijn uitgaande van de wervel kolom onder in:

- Primaire pijn: dit is pijn die uitgaat van de wervelkolom zelf of van structuren die daar dicht tegen aan liggen;

- Secundaire pijn: dit is een gevolg van primaire pijn en wordt veroorzaakt door een reactie in de spieren rondom de wervelkolom;

- Gerefereerde pijn: dit is pijn die waargenomen wordt in een gedeelte van het lichaam dat topografisch afgelegen is van de plaats waar de "bron" van de pijn is.

De zgn. primaire pijn is verder onder te verdelen en wel naar de vermeende bron van de pijn:

a. Pijn die uitgaat van de bewegende structureen van de wervelkolom, zoals de facetgewrichten en tussenwervelschijven;

b. Pijn die uitgaat van de meer oppervlakkig gelegen structuren van de wervelkolom, zoals ligamenten en spieren;

c. Pijn die wordt veroorzaakt door compromittering van een uittredende segmentale zenuw.

Patiënten met pijnklachten zonder specifieke oorzaak worden vaak symptomatisch behandeld door middel van pijnmedicatie, fysiotherapie, manuele therapie of met transcutane zenuwstimulatie. Ondanks deze therapieën blijt er toch een subgroep bestaan die niet op bovengenoemde therapie reageert. Het verdere beleid bij deze patiënten is afhankelijk van de aan- of afwezigheid van nociceptie. Nociceptieve pijn 
van het te behandelen niveau verricht, om eventuele schade aan de motorische vezels of de (aanvoerende) gemyeliniseerde vezels aan te tonen. Tevens werden de bijeffekten van de behandeling en het effekt op de pijn geregistreerd.

$\mathrm{Na}$ de behandeling liet het EMG geen tekenen van denervatie zien. Bij één patiënt was de SEP afwijkend na de behandeling.

Er was een pijnklachten vermindering 3 maanden na de behandeling bij $75 \%$ van de patiënten. $\mathrm{Na} 6$ maanden was dit aantal afgenomen tot $50 \%$.

In hoofdstuk 7: werd een klinische evaluatie verricht naar de effecten van RF-DRG bij patiënten met chronische thoracale pijn.

De patiënten werden geselecteerd voor de behandeling na twee of meer diagnostische blokkaden. Het niveau dat de beste tijdelijke pijnklachtenreductie gaf werd geselecteerd voor een RF=DRG.

De behandeling gaf op korte termijn ( 8 weken) bij $67 \%$ van de patiënten pijnklachtenreductie en op lange termijn (36 weken) bij 52\% van de patiënten met een beperkte lokalisatie van hun thoracale pijn.

In hoofdstuk 8: werden placebo-gecontroleerde effekten van de behandeling onderzocht in een prospectieve dubbelblinde gerandomiseerde studie uitgevoerd bij patiënten met chronische eenzijdige cervicobrachialgie.

Twintig opeenvolgende patiënten met tenminste 1 jaar klachten werden gerandomiseerd en toegewezen aan één van de twee volgende groepen. Groep 1 werd behandeld met een RF-lesie van $67^{\circ} \mathrm{C}$. Groep 2 werd op dezelfde manier behandeld, maar er werd geen lesie gemaakt. Een week voor de behandeling en acht weken na de behandeling werd de invloed van de behandeling op de pijnbeleving gemeten, gebruik makend van verschillende testen. Deze testen toonden aan dat er na de behandeling een significant aantal patiënten in groep 1 pijnklachtenreductie aangaven in vergelijk met groep 2.

\section{CONCLUSIE}

a. De morfologische veranderingen in het dorsale ganglion na een RF-DRG.

Een RF-DRG resulteerde in een destructie van gemyeliniseerde zenuwvezels twee weken na de behandeling (onderzocht door middel van lichtmicroscopie en HE-kleuring). Deze veranderingen werden niet gezien in het dorsale ganglion als de lesie niet in maar dichtbij het ganglion gemaakt was. Indien echter een immunohistochemische techniek gebruikt werd vertoonden de satelietcellen in het zenuwweefsel een verhoogde MIB-1 activiteit ten teken van proliferatie en regeneratie van zenuwweefsel. Deze bevinding toont aan dat het effect van een RF-leșie groter is dan zichtbaar is bij routine lichtmicroscopie. 
d. Is behandeling van chronische pijn uitgaande van de wervelkolom met een RF-DRG effectiever dan een placebo behandeling?

In hoofdstuk 2: worden de geschiedenis en de theoretische aspekten van RF-lesies besproken.

Een literatuuroverzicht, betreffende de grootte van de lesie, bij gebruik maken van verschillende electrodendikte en temperaturen van de electrode tip, wordt gegeven. Ook wordt het effect van RF-lesies op zenuwweefsel besproken.

In hoofdstuk 3: wordt een bespreking gegeven van de overwegingen die vooraf dienen te gaan aan de behandeling van spinale pijn met RF-technieken. Verschillende classificaties van pijn en van pijn uitgaande van de wervelkolom worden besproken. De innervatie van de wervelkolom wordt kort besproken evenals de diagnostiek en de rol van diagnostische blokkaden bij de behandeling met RF-lesies.

In hoofdstuk 4: wordt een overzicht gegeven van de klinische syndromen in het cervicale, thoracale en lumbale gebied die relevant zijn voor de behandeling met RF-lesies. Tevens worden de technieken besproken.

In hoofdstuk 5: worden de resultaten vermeld van morfologisch onderzoek van het dorsale ganglion onderzocht bij twee geiten. Onder röntgendoorlichting werden $22 \mathrm{G}$ $100 \mathrm{~mm}$ SMK electroden met $5 \mathrm{~mm}$ actieve tip, dichtbij (achter) het dorsale ganglion geplaatst op het lumbale niveau L1-L5. Aan één kant werden 60 seconden $67^{\circ} \mathrm{C}$ RF-lesies gemaakt. Aan de andere kant werden de naalden op dezelfde manier gepositioneerd, maar werden geen RF-lesies gemaakt. Twee weken na de procedure werden de geiten opgeofferd en alle lumbale ganglia unitgenomen. De ganglia werden bestudeerd en er werd gekeken naar de grootte van de ontstane lesie, maar ook naar proliferatie en regeneratie van zenuwweefsel m.b.v. Ki-67 (MIB-1).

Bij de twee geiten was op niveau L5 met opzet de lesie in het dorsale ganglion gemaakt.

De lesies, in het L5-ganglion waren 1.8-2.0 mm in doorsnede en lieten bij lichtmicroscopie en routine HE-kleuring een volledig verlies van gemyeliniseerde vezels zien. Deze veranderingen werden niet gezien in de ganglia waar de lesie dichtbij het ganglion gemaakt was. In deze ganglia werden echter bij de immunohistochemische techniek. (MIB-1) veranderingen waargenomen. Er was een significante hogere MIB-1 activiteit in de ganglia waar de lesie dichtbij het ganglion gemaakt werd in vergelijk met de placebo zijde.

In hoofdstuk 6: werd bij 20 patiënten met chronische nek-schouderklachten gezocht naar eventuele denervatie na een RF-DRG. De patiënten werden geselecteerd voor de behandeling met een RF-lesie na tenminste drie diagnostische proefblokkaden (C4, C5, C6). Het niveau dat het beste tijdelijke pijnklachtenreductie gaf werd geselecteerd voor behandeling met een RF-DRG. Voor en drie weken na de behandeling werden een electromyografie (EMG) en een sensory evoked potential (SEP) 
van het te behandelen niveau verricht, om eventuele schade aan de motorische vezels of de (aanvoerende) gemyeliniseerde vezels aan te tonen. Tevens werden de bijeffekten van de behandeling en het effekt op de pijn geregistreerd.

Na de behandeling liet het EMG geen tekenen van denervatie zien. Bij één patiënt was de SEP afwijkend na de behandeling.

Er was een pijnklachten vermindering 3 maanden na de behandeling bij $75 \%$ van de patiënten. Na 6 maanden was dit aantal afgenomen tot $50 \%$.

In hoofdstuk 7: werd een klinische evaluatie verricht naar de effecten van RF-DRG bij patiënten met chronische thoracale pijn.

De patiënten werden geselecteerd voor de behandeling na twee of meer diagnostische blokkaden. Het niveau dat de beste tijdelijke pijnklachtenreductie gaf werd geselecteerd voor een RF-DRG.

De behandeling gaf op korte termijn ( 8 weken) bij $67 \%$ van de patiënten pijnklachtenreductie en op lange termijn (36 weken) bij 52\% van de patiënten met een beperkte lokalisatie van hun thoracale pijn.

In hoofdstuk 8: werclen placebo-gecontroleerde effekten van de behandeling onderzocht in een prospectieve dubbelblinde gerandomiseerde studie uitgevoerd bij patiënten met chronische eenzijdige cervicobrachialgie.

Twintig opeenvolgende patiënten met tenminste 1 jaar klachten werden gerandomiseerd en toegewezen aan één van de twee volgende groepen. Groep 1 werd behandeld met een RF-lesie van $67^{\circ} \mathrm{C}$. Groep 2 werci op dezelfde manier behandeld, maar er werd geen lesie gemaakt. Een week voor de behande!ing en acht weken na de behandeling werd de invloed van de behandeling op de pijnbeleving gemeten, gebruik makend van verschillende testen. Deze testen toonden aan dat er na de behandeling een significant aantal patiënten in groep 1 pijnklachtenreductie aangaven in vergelijk met groep 2 .

\section{CONCLUSIE}

a. De mortologische veranderingen in het dorsale ganglion na een RF-DRG.

Een RF-DRG resultẹerde in een deștructie van gemyeliniseerde zenuwvezels twee weken na de behandeling (onderzocht door middel van lichtmicroscopie en HE-kleuring). Deze veranderingen werden niet gezien in het dorsale ganglion als de lesie niet in maar dichtbij het ganglion gemaakt was. Indien echter een immunohistochemische. techniek gebruikt werd vertoonden de satelietcellen in het zenuwweefsel een verhoogde MIB-1 activiteit ten teken van proliferatie en regeneratie van zenuwweefsel. Deze bevinding toont aan dat het effect van een RF-lesie groter is dan zichtbaar is. bij routine lichtmicroscopie. 


\section{b. Tekenen van denervatie na een RF-DRG.}

Electromyelografieën uitgevoerd bij 17 patiènten toonden geen tekenen van denervatie van motorische vezels na een RF-DRG.

Eén sensory evoked potential veranderde na de behandeling ten teken dat er enige schade was van aanvoerende gemyeliniseerde vezels. De meest voorkomende bijwerking van de behandeling was een tijdelijke brandende pijn in het behandelde gebied. Een tijdelijk verminderde sensibiliteit in het dermatoom werd in $35 \%$ van de gevallen gezien. Met uitzondering van één patiënt waren de bij-effekten van de behandeling na 6 weken verdwenen.

\section{c. Het klinische effect op de pijnbeleving na een RF-DRG.}

Het klinische effect van de behandeling werd geëvalueerd bij patiènten met chroni= sche thoracale pijn en bij patiënten met chronische cervicobrachialgie.

In de patiēntengroep met de cervicobrachialgie was er bij $75 \%$ een pijnklachtenreductie 3 maanden na de behandeling. In een periode van 3 tot 9 maanden keerde de oorspronkelijke pijn bij $35 \%$ van de patiënten die klachtenreductie had weer terug. Op thoracaal niveau gaf een RF-DRG na 8 weken bij $67 \%$ van de patienten, met beperkte localisatie van hun pijn, klachtenreductie. Op langer termijn (36. weken) was dit aantal $52 \%$. Indien de thoracale pijn over meerdere segmenten verspreid was. was de behandeling minder effectief.

\section{d. De effektiviteil van een RF-DRG bij patiènten met chronische cervicobrachialgie vergeleken met placebo.}

De resultaten van dit prospective gerandomiseerde onderzoek toonden aan dat 8 weken na de behandeling er significant meer patiënten met pijnklachtenreductie waren in de RF-groep in vergelijking met de placebo-groep.

Deze studie toont aan dat een RF-DRG chronische cervicale klachten kan reduceren.

\section{ALGEMENE CONCLUSIE}

We hebben een techniek onderzocht waarbij een RF-DRG gemaakt wordt. Met behulp van deze techniek zijn we in staat om bij een geselecteerde groep chronische pijnpatiënten op korte termijn pijnklachtenreductie te bereiken in $67-75 \%$ van de patiënten, zonder ernstige bij-effekten van de behandeling. Op langere termijn nemen de effekten van de behandeling af. In een subgroep zijn de lange termijn effekten van een RF=DRG 40-52\%.

Het afnemen van het effect kan veroorzaakt worden ofwel door de multisegmentale innervatie van de wervelkolom, ofwel door regeneratie van zenuwweefsel. 
In het ene geval zou men kunnen overwegen om meerdere RF-lesies aan te brengen in een poging om een beter resultaat op langere termijn te verkrijgen. In het andere geval kan de behandeling worden herhaald. Dit kan zonder bezwaar gebeuren omdat bij morfologisch en neurofysiologisch onderzoek is aangetoond dat de behandeling uitgevoerd kan worden zonder schade toe te brengen aan motorische vezels.

Een andere methode om de afname in klinische effectiviteit te reduceren zou mogelijkerwijs de combinatie zijn van RF-lesies met revalidatieprogramma's. De periode van pijnvermindering zou dan gebruikt kunnen worden om maximaal profijt te trekken uit conservatieve methoden, zoals revalidatie en verbetering van functie. Deze mogelijkheid zou onderwerp kunnen zijn van toekomstig onderzoek. 


\section{Dankwoord}

Graag wil ik de mensen bedanken die een bijdrage hebben geleverd aan het tot stand komen van dit proefschrift.

Prof. Dr. S. de Lange, beste Simon, onder jouw leiding heeft de afdeling Anesthesiologie een belangrijk "academisch" proces doorgemaakt. Hierdoor zullen de komende jaren meer promoties volgen.

Dit proefschrift is tot stand gekomen doordat jij inzag dat de pijnbestrijding een wezenlijk onderdeel is van de Anesthesiologie. Door deze visie was het mogelijk, met medewerking van de Medische Faculteit van de Rijksuniversiteit Limburg, in Nederland de eerste hoogleraar "Pijnbestrijdingstechnieken" aan te stellen. Verder dank ik je voor je goede adviezen en de plezierige begeleiding bij de totstandkoming van dit proefschrift.

Prof. Dr. M.E. Sluijter, beste Menno, iedereen weet dat jij van doorslaggevend belang bent geweest bij dit proefschrift. De onderzochte pijnbestijdingsmethoden zijn voor een groot gedeelte door jou bedacht of verder ontwikkeld. Het is voor mij een eer om met je te mogen werken.

Het is gebleken dat onze samenwerking een combinatie van eigenschappen oplevert die van belang blijken te zijn voor het initiëren en uitvoeren van wetenschappelijk onderzoek. Ik hoop dat we in de toekomst deze samenwerking en onze vriendschap nog lang kunnen voortzetten.

Gerard Barendse, Wout Dingemans, Hans van Suijlekam en Wim Weber hebben door hun bijdrage in de vele discussies over onderzoek naar invasieve pijnbestijdingstechnieken een belangrijk aandeel gehad in dit proefschrift. Met name Gerard en de collega-anesthesiologen ben ik veel dank verschuldigd, omdat zij het mij mogelijk maakten tijdi vrij te maken voor onderzoek.

Gerard Freling, Marcel Herpers, John Paulissen en de medewerkers van het laboratorium Fysiologie en Klinische Neurofysiologie dank ik hartelijk voor hun steun bij de onderzoeken die op deze afdelingen plaatsgevonden hebben. Met name John dank ik voor al zijn geduld.

Fons Kessels en Richel Lousberg dank ik voor de methodologische adviezen en de wetenschappelijke analyse van de beschikbare data. Helma Voets dank ik voor het verzamelen van de data.

De verpleegkundigen van het Dagcentrum, met name Maria en Marie-Paule, dank ik voor hun bijdrage aan de onderzoeken en de goede samenwerking in de afgelopen 12 jaar. 
Verder dank ik de leden van de Beoordelingscommissie voor het kritisch doorlezen van het proefschrift en hun waardevolle opmerkingen.

Van zeer groot belang is Patrice Florax. Dit proefschrift is namelijk met vulpen geschreven. Patrice heeft er voor gezorgd dat het in boekvorm kan verschijnen. Voor mij is zij (de) secretaresse van het jaar.

Marianne, Eva, Anna en Lotte wilde in dit proefschrift niet bedankt worden. Dit doe ik dan ook niet. 


\section{Curriculum Vitae}

Maarten van Kleef was born on December 19th, 1953 in Rotterdam, the Netherlands. He attended the secondary school (HBS-B) at the Scholengemeenschap Melanchton in Rotterdam from 1966 to 1972. He studied medicine at the University of Amsterdam and obtained his medical degree in 1980. For his national service committment from 1980 to 1981 he worked as trainee military doctor in anaesthesiology in the Binnengasthuis Hospital in Amsterdam. Commencing in 1981 at the University Hospital of Amsterdam (AMC) he completed his training in anaesthesiology in 1985 under professor Vermeulen-Cranch and later Prof. Dr. Deen. Since 1985 he has been staff member in the department of Anaesthesiology at the University Hospital of Maastricht (Prof. Dr. Simon de Lange). 


\section{Publications and Abstracts}

\section{Publications}

M.J.H.M. Jacobs, R. Beckers, D.T. Ubbink, M. van Kleef, D.W. Slaaf and R.S. Reneman. Foot salvage and improvement of microvascular blood flow as a result of epidural spinal cord electrical stimulation. Journal of Vascular Surgery, 1990; 12: 354-860.

M.E. Sluijter, M. van Kleef and G.A.M. Barendse. Occipital nerve block in the management of headache and cervical pain. Cephalalgia, 1992; 12: 325-327.

M. van Kleef, F. Spaans, W.A.A.M. Dingemans, G.A.M. Barendse, E. Floor and M.E. Sluijter. Effects and side-effects of a percutaneous thermal lesion of the dorsal root ganglion in patients with cervical pain syndrome. Pain, 1993; 52: 49-53.

W. Dingemans, N. Groenman en M. van Kleef. Pijn en pijnbehandeling; een basaal onderwijs curriculum. Universitaire Pers, ISBN 90-5278-081-1, 1993.

H. Evers and M. van Kleef. Pain and endometriosis. Genesis, 1994; 5: 3-5.

M. van Kleef, G.A.M. Barendse, W.A.A.M. Dingemans, C. Wingen, R. Lousberg, S. de Lange and M.E. Sluijter. Effects of producing a radiofrequency lesion adjacent to the dorsal root ganglion in patients with thoracic segmental pain. The Clinical Journal of Pain, 1995; 11: 325-332.

M. van Kleef, G.A.M. Barendse, R. Lousberg, J.A. van Suijlekorn, W.A.A.M. Dingemans, S.K. Bulstra en M.E. Sluijter. Eerste klinische ervaringen met radiofrequente laesie van de discus intervertebralis bij patiënten met lage rugklachten. Nederlands Tijdschrift voor Pijn en Pijnbestrijding, 1995; 15: 13-17.

J.A. van Suijlekom, M. van Kleef, G.A.M. Barendse, W.A.A.M. Dingemans, M.E. Sluijter. Invasieve pijnbestrijdingstechnieken bij cervicobrachialgie ten gevolge van whiplash. Nederlands Tijdschrift voor Pijn en Pijnbestrijding, 1995; 3: 40-42.

M. van Kleef and M.E. Sluijter. Initial experience with radiofrequency heating of the intervertebral disc in the treatment of posttraumatic cervical pain. In: Management of Pain - A World Perspective. P. Raj, S. Erdine, D. Niv, S. Raja (eds.) Monduzzi Editore, Bologna, Italy, pp. 543-550, 1995. 
M. van Kleef, L. Liem, R. Lousberg, G. Barendse, F. Kessels, M. Sluijter. Radiofrequency lesion adjacent to the dorsal root ganglion for cervicobrachial pain: a prospective double blind randomized study. Neurosurg 38:1127-1132, 1996.

E.V. Rouwet, G.H. Spincemaille, G. Barendse, M. van Kleef, E.M.M. Adang, H.A.J.M. Kurvers, M.A.R.C. Daemen, F.A.J.M. van den Wildenberg. Spinal cord stimulation in de behandeling van reflex sympathische dystrofie. Nederlands Tijdschrift voor Pijn Pijnbestrijding, 1: 1996, pp. 8-11.

M. van Kleef, M.E. Sluijter. Treatment of spinal pain with radiofrequency techniques. Chapter in Handbook of Stereotactic and Functional Neurosurgery. Gildenberg Ph. and Tasker R.R., (eds.). Publisher McGraw-Hill, to be published in 1996.

M. van Kleef, G. Barendse, J. Wilmink, R. Lousberg, S. Bulstra, W. Weber, M. Sluyter. Percutaneous intradiscal radiofrequency thermocoagulation in chronic non-specific low back pain. Accepted for publication in The Pain Clinic, issue 3, 1996.

\section{Abstracts}

M. van Kleef, J. Schreuder, J. Biervliet and L. Deen. Haemodynamic effects of synchronised high frequency jet ventilation. Abstract Intensive Care Congress, Barcelona 1982.

M. van Kleef, M.E. Sluijter. Initial experience with RF-heating of the intervertebral disc in the treatment of post-traumatic cervical pain. 6th International Congress Pain Clinic, Aprill 1994, Atlanta.

M. van Kleef, G. Barendse, J. Wilmink, H. van Suijlekom and M. Sluijter. One year experience with treatment of discogenic low back pain by radiofrequency heating of the intervertebral disc. 1St Scientific Meeting of the European Federation of IASP Chapters. Pain in Europe, Verona, May 18-21, 1995.

M. Sluijter and M. van Kleef. Factors governing the size of radiofrequency lesions = Description of a computer model. 1St Scientific Meeting of the European Federation of IASP Chapters. Pain in Europe, Verona, May 18-21, 1995.

G. Barendse, M. van Kleef, W. Dingemans and M. Sluijter. Sphenopalatine ganglion block as a treatment for medication-resiștant cluster headache. 1St Scientific Meeting of the European Federation of IASP Chapters. Pain in Europe, Verona, May 18-21, 1995.

E. Rouwet, H. Kurvers, M. Daemen, D. Slaaf, M. van Kleef, G. Barendse, F. van den Wildenberg and P. Kitslaar. Antidromic and sympathetic mechanisms in a rat model 
of neuropathic pain. 1St Scientific Meeting of the European Federation of IASP Chapters. Pain in Europe, Verona, May 18-21, 1995.

M. Daemen, H. Kurvers, E. Rouwet, G. Spincemaille, E. Adang, P. Kitslaar, G. Barendse, M. van Kleef and F. van den Wildenberg. Spinal cord stimulation: a new approach in the treatment of long standing reflex sympathetic dystrophy. 1St Scientific Meeting of the European Federation of IASP Chapters. Pain in Europe, Verona, May 18-21, 1995.

H. Kurvers, F. Stassen, D. Slaaf, E. Rouwet, M. Daemen, F. van den Wildenberg, M. van Kleef, G. Barendse, P. Kitslaar, M. Jacobs and J. de Mey. Loose ligation of the rat sciatic nerve induces autonomic denervation and hypersensitivity to catecholamines. 1St Scientific Meeting of the European Federation of IASP Chapters. Pain in Europe, Verona, May 18-21, 1995.

J. van Suylekom, M. van Kleef, G. Barendse. The outcome of treatment of posttraumatic cervical pain with radiofrequency (RF) lesions. 8th World Congress on Pain, Vancouver, British Columbia, Canada, August 17-22, 1996. 

